Florida International University FIU Digital Commons

5-11-2011

\title{
An Examination of Accounting and Auditing Issues Related to Strategic Environmental Initiatives
}

Barri A. Litt

Florida International University, barrilitt@gmail.com

DOI: $10.25148 /$ etd.FI11072504

Follow this and additional works at: https://digitalcommons.fiu.edu/etd

\section{Recommended Citation}

Litt, Barri A., "An Examination of Accounting and Auditing Issues Related to Strategic Environmental Initiatives" (2011). FIU Electronic Theses and Dissertations. 421.

https://digitalcommons.fiu.edu/etd/421 


\section{FLORIDA INTERNATIONAL UNIVERSITY}

Miami, Florida

\section{AN EXAMINATION OF ACCOUNTING AND AUDITING ISSUES RELATED TO STRATEGIC ENVIRONMENTAL INITIATIVES}

A dissertation submitted in partial fulfillment of the

requirements for the degree of

DOCTOR OF PHILOSOPHY

in

BUSINESS ADMINISTRATION

by

Barri Alexandra Litt 
To: Dean Joyce J. Elam

College of Business Administration

This dissertation, written by Barri Alexandra Litt, and entitled An Examination of Accounting and Auditing Issues Related to Strategic Environmental Initiatives, having been approved in respect to style and intellectual content, is referred to you for judgment.

We have read this dissertation and recommend that it be approved.

$\begin{array}{r}\hline \text { Suchismita Mishra } \\ \hline \text { Abhijit Barua } \\ \hline \text { Kannan Raghunandan, Co-Major Professor } \\ \hline \text { Dasaratha Rama, Co-Major Professor }\end{array}$

Date of Defense: May 11, 2011

The dissertation of Barri Alexandra Litt is approved.

Dean Joyce J. Elam
College of Business Administration

Interim Dean Kevin O'Shea

University Graduate School

Florida International University, 2011 


\section{DEDICATION}

I dedicate this dissertation to my dear family and closest friends. Without their unwavering support, guidance, humor, and love, the completion of this work would not have been possible. I especially recognize my mother, Toby Litt whose presence, although not physical, has helped give me the wisdom, ability, and motivation to reach for my dreams. 


\section{ACKNOWLEDGMENTS}

I wish to thank the members of my committee for their support, especially my major professor, Dr. Kannan Raghunandan whose wisdom and commitment has guided me through the program from the very beginning. I would also like to extend exceptional gratitude to Dr. Divesh Sharma who has been a pivotal and inspirational figure during this monumental period in my life. He unselfishly mentored me and provided invaluable insights about the intricacies and subtleties of academic research. Finally, I thank Dr. Vineeta Sharma for her continuous commitment, comments and suggestions throughout this project. 


\title{
ABSTRACT OF THE DISSERTATION \\ AN EXAMINATION OF ACCOUNTING AND AUDITING ISSUES RELATED TO \\ STRATEGIC ENVIRONMETNAL INITIATIVES
}

\author{
by
}

\section{Barri Alexandra Litt}

Florida International University, 2011

Miami, Florida

\section{Professor Kannan Raghunandan, Major Professor}

Although corporate environmental accountability is receiving unprecedented attention in the United States from policy makers, the capital market, and the public at large, extant research is limited in its examination of the implications of strategic corporate environmental initiatives on accounting and auditing. The purpose of my dissertation is to address these implications by examining the association between firm environmental initiatives and audit fees, capital expenditures, and earnings quality using multivariate regression analysis. I find that firms engaged in more strategic environmental initiatives tend to have significantly higher audit fees and capital expenditures, and significantly lower levels of earnings manipulation measured using discretionary accruals. These results support the notion that auditors do recognize the importance of environmental initiatives when conducting the year-end financial statement audit, an idea that positively reflects upon the auditor's monitoring role. The results also demonstrate the increased amount of capital resources required to participate in strategic environmental initiatives, an anecdotal notion that had yet to be empirically supported. This empirical support provides valuable insights on how environmental initiatives 
materially impact corporate financial statements. Finally, my results extend the extant literature by demonstrating that the superior financial performance reported by environmentally active firms is less likely driven by earnings manipulation by management, and by implication, more likely a result of real economic gains. Taken together, my dissertation establishes a strong and timely foundation for current and future research to explore corporate environmental initiatives in the United States and globally, a topic increasingly gaining momentum in today's more eco-conscious world. 


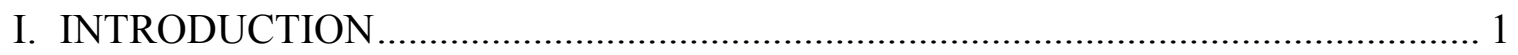

II. ENVIRONMENTAL INITIATIVES AND AUDIT FEES ………………………...... 4

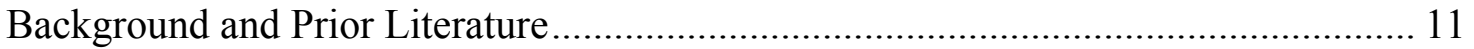

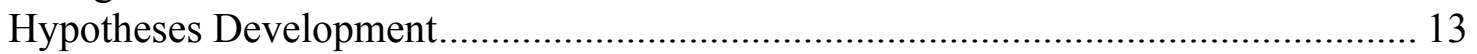

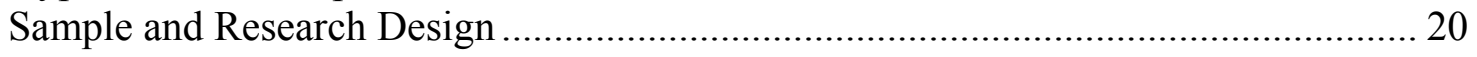

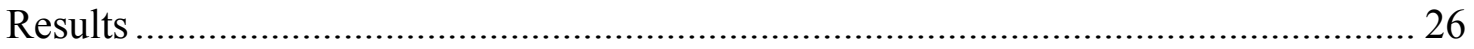

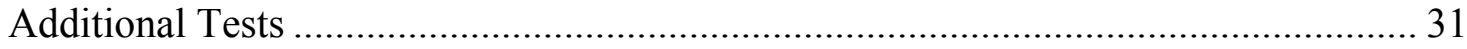

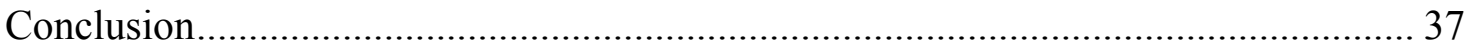

III. ENVIRONMENTAL INITIATIVES AND CAPITAL EXPENDITURES ................ 40

Background and Prior Literature............................................................................ 43

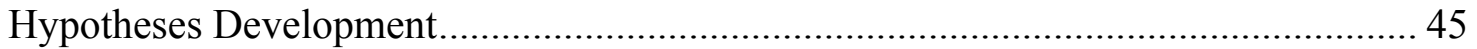

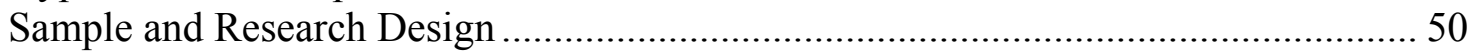

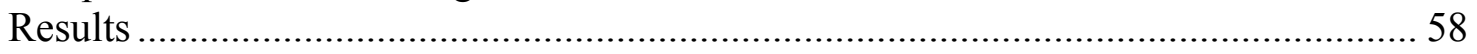

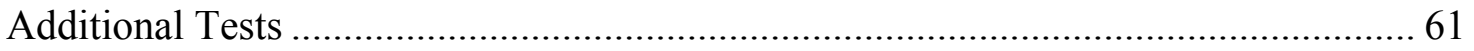

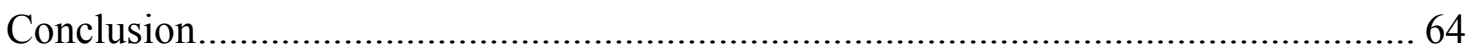

IV. ENVIRONMENTAL INITIATIVES AND EARNINGS MANAGEMENT ............. 67

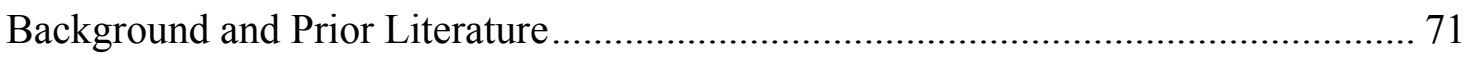

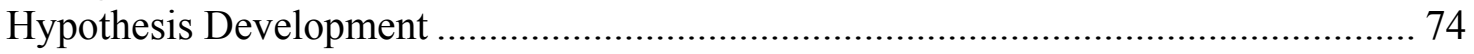

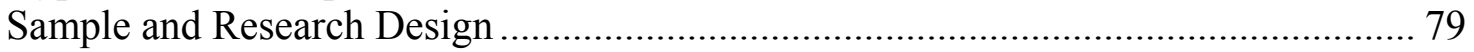

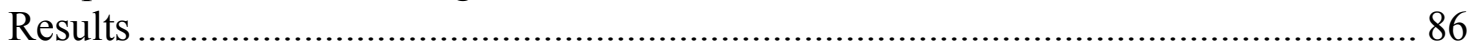

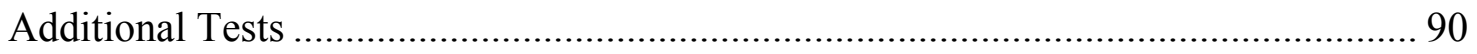

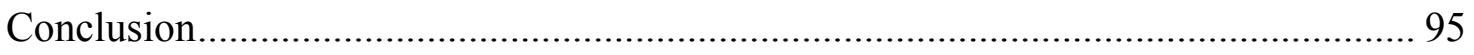

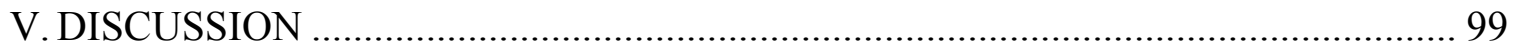

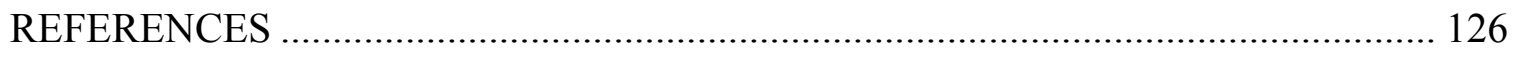

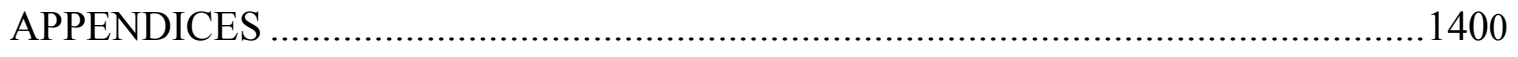

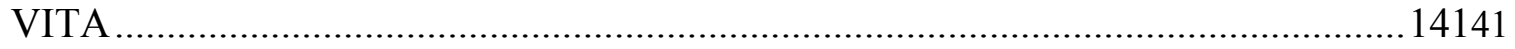




\section{LIST OF TABLES}

TABLE

PAGE

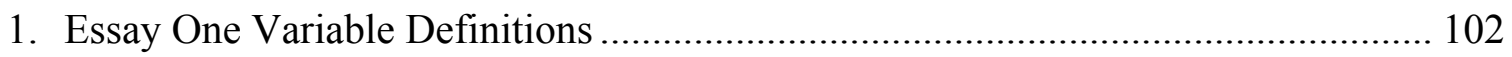

2. Descriptive Statistics for Environmental Initiatives.................................................. 103

3. Descriptive Statistics for Essay One Full Sample and for Firms with and without

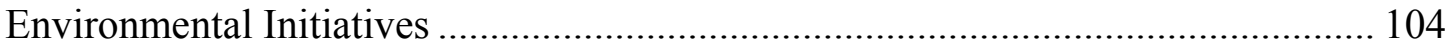

4. Essay One Pearson and Spearman Correlations...................................................... 105

5. Regression of Audit Fees on Environmental Initiatives............................................ 107

6. Regression of Audit Fees on Environmental Initiative Indicator and Types of Initiatives 108

7. Regression of Audit Fees on Environmental Initiatives Conditional on Capital Expenditure

8. Essay Two Variable Definitions ……………………......................................... 110

9. Descriptive Statistics for Essay Two Full Sample and for Firms with and without

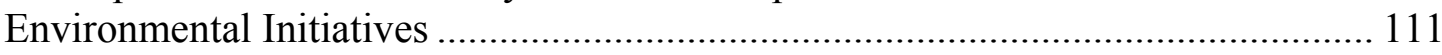

10. Essay Two Pearson and Spearman Correlations..................................................... 112

11. Regression of Capital Expenditures on Environmental Initiatives ........................... 114

12. Regression of Capital Expenditures on Any Environmental Initiative Participation 115

13. Regression of Capital Expenditures on Environmental Initiative Types 116

14. Essay Three Variable Definitions

15. Descriptive Statistics for Essay Three Full Sample and for Firms with High and Low Discretionary Accruals 118

16. Essay Three Pearson and Spearman Correlations. 119

17. Regression of Absolute Value of Discretionary Accruals on Environmental Initiatives 
18. Regression of Income-Increasing Discretionary Accruals on Environmental Initiatives

19. Regression of Absolute Value of Discretionary Accruals on Environmental Initiative Indicator

20. Regression of Income-Increasing Discretionary Accruals on Environmental Initiative Indicator 123

21. Regression of Absolute Value of Discretionary Accruals on Types of Environmental Initiatives 124

22. Regression of Income-Increasing Discretionary Accruals on Types of Environmental Initiatives 125 


\section{AN EXAMINATION OF ACCOUNTING AND AUDITING ISSUES RELATED TO STRATEGIC ENVIRONMENTAL INITIATIVES}

\section{INTRODUCTION}

Corporate social and environmental responsibility is receiving an unprecedented level of attention in the United States today relative to the past (Social Investment Forum 2010). Regulators, market participants, the media, and the public at large appear to be placing more value on environmental accountability, a trend that is certainly expected to continue given recent corporate environmental disasters such as the British Petroleum oil spill. Authoritative bodies such as the Securities and Exchange Commission are undertaking considerable measures to enhance environmental disclosure and transparency (SEC 2010). These environmental accountability initiatives accompany the enormous growth in socially and environmentally responsible investments over the past twenty years, which have grown from $\$ 639$ billion in 1995 to over $\$ 3.07$ trillion as of 2010 (Social Investment Forum 2010). Despite this pervasive focus on corporate environmental responsibility, extant literature is limited on the potential implications of firms' participation in environmental initiatives on accounting and auditing. In my dissertation, I address such implications by examining firms' involvement in strategic environmental initiatives in various accounting and auditing contexts.

My doctoral dissertation consists of three essays that examine accounting and auditing issues related to strategic environmental initiatives. These issues examine environmental initiatives as they relate to audit fees, capital expenditures, and earnings management. 
My first dissertation essay examines the association between firm environmental initiatives and audit fees, an established proxy for audit effort. This examination is particularly timely, given the recent call by the President and Chief Executive Officer of the American Institute of Certified Public Accountants for the auditing profession to be more proactive on examining environmental issues (Melancon 2010). By examining the impact of environmental initiatives on audit fees, I provide initial evidence on the extent of auditor consideration of such initiatives, which are of increasing regulatory, market, and public importance. I find evidence that auditors do, in fact, appear to consider environmental initiatives in their audit pricing, thus supporting the notion that auditors are paying attention to the increasing importance of corporate environmental considerations. I also report findings on how specific types of environmental initiatives relate to audit fees in order to add further insight to my analyses.

In consideration of my first essay's finding that auditors appear to consider environmental initiatives during the annual financial statement audit, a logical progression is to examine more specifically how these initiatives impact the corporate financial statements being audited. I examine the impact of corporate strategic environmental initiatives on capital expenditures, a major financial statement component cited anecdotally as being heavily influenced by a firm's investment in environmental initiatives (ChevronTexaco 2004; 2005; 2006; SEC 2010, Plank 2010; Mitchell 2010). I provide the first empirical support for this association by investigating environmental initiatives as a potential determinant of capital expenditures. My results indicate higher capital expenditures for firms with environmental initiatives, supporting the notion that 
such initiatives require significant capital investment, which is reflected in the financial statements. I also examine how specific types of environmental initiatives are related to capital expenditures.

While my first two essays analyze the audit and financial reporting implications of environmental initiatives from the auditor's and participating corporations perspectives, an area of significant interest to the market is the quality of earnings reported by these corporations: this is the topic of my third dissertation essay. Extant literature shows superior financial performance for firms with strong environmental performance (Bragdon and Marlin 1972; Spicer 1978; Douglas and Judge 1995; Guenster et al. 2006; Semenova and Hassel 2008). However, several studies also find that firms reporting superior financial performance tend to engage in greater levels of earnings management, potentially overstating the level of actual economic gains attained (Burgstahler and Dichev 1997; Payne and Robb 2000; Dechow et al. 2000; Matsumoto 2002; Das and Zhang 2003; Abarbanell and Lehavy 2003; Lin et al. 2008). A natural question, then, is to what extent do firms engaged in environmental initiatives manage their earnings to report their aforementioned superior financial performance? I provide insight into this question by examining strategic environmental initiatives as they relate to a firm's propensity to manage earnings, as measured by performance-adjusted modifiedJones model discretionary accruals (Kothari 2005). My findings support lower levels of earnings management for firms involved in environmental initiatives, suggesting that the superior financial performance reported by these firms is more likely a result of real economic gains than of intentional earnings manipulation on the part of management. I 
also examine how specific environmental initiative types affect this association with earnings management.

I organize the following dissertation by presenting each of these three essays in Chapter II, III, and IV, respectively. I conclude with a discussion of the overall results and contributions of my dissertation in Chapter V.

\section{ENVIRONMENTAL INITIATIVES AND AUDIT FEES}

Amid increasing societal pressures, media attention and capital market interest, Congress and corporate regulators have gradually increased their focus on corporate environmental responsibility. For example, the Securities and Exchange Commission (SEC) recently issued an environmental disclosure guideline to increase corporate America's accountability to stakeholders and is considering mandating such disclosures

(SEC 2010). ${ }^{1}$ Developments of such guidelines complement the burgeoning stock market emphasis on socially and environmentally responsible investment funds and issuers. Over the past twenty years, there has been unprecedented growth in socially responsible mutual funds and market indices, with investments growing exponentially from $\$ 639$

\footnotetext{
${ }^{1}$ This SEC interpretive release entitled Commission Guidance Regarding Disclosure Related to Climate Change more thoroughly outlines an organization's responsibility to disclose existing and potential climate change effects on annual report items such as the description of business, risk factors, environmental capital expenditures, and legal and regulatory disclosures. Compliance with this guideline is currently not mandatory although the SEC is considering introducing some mandatory disclosure requirements.
} 
billion to $\$ 3.07$ trillion between 1995 and 2010 (Social Investment Forum 2010). ${ }^{2}$ Shareholders are even going so far as demanding companies to terminate their relationships with companies presenting high environmental risk (Allen et al. 2010). The market's focus on environmental issues suggests the need for more extensive and credible information about the implications of an issuer's environmental initiatives. ${ }^{3}$

To add credibility to a client's environmental initiatives, the external financial statement independent auditors (hereafter auditor(s)) are considered one of the most appropriate assurance providers because they possess thorough understanding of the client including the internal and external environment, business strategies, controls and financial transactions, amongst other client aspects (Simnett et al. 2009a; 2009b). However, related evidence suggests auditors in the U.S. do not emphasize a client's environmental initiatives (KPMG 2002; 2005). The low rate of assurance in the U.S. is likely due to the lack of guidance in U.S. auditing standards (Simnett et al. 2009a; 2009b) and heightened litigation risk (Herda and Taylor 2010). Even though investors are placing more emphasis on non-financial information related to corporate social responsibility (Dhaliwal et al. 2010a), prior research shows that auditors neglect and do

\footnotetext{
${ }^{2}$ Organizations providing such mutual funds include Ariel Funds, Pax World Balanced Funds, New Alternatives Funds, and Green Century Funds; and indices include the KLD Index under the RiskMetrics Group and the Dow Jones Sustainability Index.

3 I define environmental initiatives as strategic actions taken by a company that resonates with environmentally friendly characteristics such as reducing pollution and waste, using energy-efficient products and processes, recycling, using renewable energy and clean fuels. A company's response to address an environmental violation standard (EPA) is not considered a strategic environmental initiative because the action was initiated by a regulator. In additional analyses, I consider such environmental violations.
} 
not place high priority on non-financial information in the performance of the audit (e.g., Hirst and Koonce 1996; Brazel et al. 2010; Trompeter and Wright 2010).

However, this stance could take an unprecedented shift. Recently, Barry Melancon, President and CEO of the AICPA recognized and called upon the profession to take a proactive role and increase attention to sustainability reporting and auditing. Mr. Melancon $(2010,5)$ proclaims that "it's time for the social and environmental aspects of conducting business to be accounted for in the U.S." and investors' increasing focus on sustainability and the financial implications of environmental initiatives are natural market forces demanding greater assurance from the auditors. The development of reporting standards on green house gas emissions and the auditor's potential role in providing assurance on such emissions (Simnett et al. 2009b) highlight the relevance and importance of environmental initiatives to the accounting profession.

The potential role of the auditor in providing assurance over environmental initiatives is natural because environmental initiatives have potential material financial and reporting implications (Cho et al. 2006). In its interpretive release on environmental issues, the SEC amplifies the operational and financial impact of environmental initiatives, citing specifically the significant effect such initiatives may have on capital expenditures (SEC 2010). Evidence of such implications abounds in proxy statements. For example, ChevronTexaco Corporation's Business and MD\&A sections of the 10-K discuss that its environmental projects associated with increasing air and water quality required material investments of $\$ 145$ million for environmental capital expenditures in 2004. The company's environmental capital expenditures also grew significantly 
between 2004 and 2006, from $\$ 213$ million to $\$ 385$ million, representing an $80 \%$ increase (ChevronTexaco 2004; 2005; 2006). Such investment increases are congruent with escalating regulatory, societal and investor focus on corporate environmental responsibility and signify the material financial statement implications of environmental initiatives.

However, the materiality of these costs increases the potential misreporting of environmental costs and the auditor's ability to recognize this risk. Because of the uncertainty and risks related to the outcomes of environmental initiatives, management may be motivated to deal with the associated operational and financial risks by manipulating the disclosure of outlays on environmental matters, particularly treating the outlays as capital rather than an expense. Evidence suggests that capital expenditure is one of the riskiest accounts that has been subject to material restatements and financial fraud (e.g., Beasley et al. 1999; 2010; Maremont and Cohen 2002; Pulliam and Solomon 2002; Audit Analytics Inc. 2008), and implies that auditors may have missed such misreporting.

While it is clear that environmental initiatives appear to have material financial reporting and audit implications, there is no empirical evidence that auditors incorporate such initiatives in the audit of the financial statements. Related evidence suggests otherwise. Given the absence of empirical evidence, the heightened attention to environmental initiatives from Congress, regulators, society, and investors, and the unprecedented call for the accounting profession to take a more proactive role in such 
issues, I provide the first empirical evidence of how environmental initiatives are related to the audit of the financial statements.

Specifically, I address three research questions. First, I examine the extent to which auditors consider environmental initiatives when conducting the annual financial statement audit. I articulate theoretical propositions that suggest auditors may either ignore or incorporate environmental initiatives when performing the financial statement audit. They may ignore environmental initiatives due to the lack of authoritative guidance on auditing environmental initiatives, the difficulty and lack of understanding of the economic and other implications of these initiatives, and because the initiatives are ambiguous. Alternatively, auditors may give attention to and thus incorporate environmental initiatives because they relate to a client's business risk and strategies, which they recognize have financial and audit implications, and regulators, investors, and other interested stakeholders that rely on audited information are placing more emphasis on environmental initiatives. I empirically test such possibilities through the association between environmental initiatives and audit fees.

My second research question probes further into any association between environmental initiatives and audit fees to facilitate understanding how types of environmental initiatives are related to the audit. This is an important issue because environmental initiatives can have varying financial reporting implications. Some initiatives may have significant financial implications while others may have relatively less material implications. For instance, initiatives related to pollution prevention may demand relatively greater economic resources such as material expenditures to modify or 
implement new technology, while recycling efforts may require more of a change in culture rather than significant investments in capital items. I empirically address this question by relating five specific types of environmental initiatives to audit fees.

My final research question examines the audit implications of investments in environmental initiatives captured in capital expenditures. I focus on capital expenditures as a component of the financial statements and examine if the association between environmental initiatives and audit fees is conditional on capital expenditures. Because prior audit fee research has not examined how capital expenditures are related to audit fees, nor has prior environmental research examined how environmental initiatives are related to such items in the financial statements, I rely on regulatory guidelines and anecdotes in an attempt to develop theoretical propositions on the conditional effect of capital expenditures on the association between environmental initiatives and audit fees. ${ }^{4}$ The SEC believes that meeting certain environmental initiatives would require significant capital investments. Anecdotes from proxy statements also suggest capital expenditure implications from environmental initiatives, but I do not expect all initiatives to have the same capital expenditure implications. I empirically examine these capital expenditure implications in my second dissertation study.

Based on a sample of 2,474 firm observations from 2004 to 2006 and after controlling for other determinants of audit fees, I find a significant positive association

\footnotetext{
${ }^{4}$ Other financial avenues through which environmental initiatives could influence the audit is through asset impairment (e.g., equipment does not meet environmental standards and thus needs to be replaced), provisions for obsolescence of inventory that may not comply with environmental standards, cost of environmental cleanup or rectification, and lawsuits and related contingent liability. I am unable to empirically test these due to the lack of adequate publicly available data.
} 
between environmental initiatives and audit fees. I also find that audit fees are most significantly related to initiatives regarding the use and/or development of environmentally beneficial goods and services, the implementation of strong pollution prevention programs, and a superior commitment to management systems, voluntary programs, and other environmentally proactive activities. In addition, I find that the association between environmental initiatives and audit fees is more pronounced when capital expenditures are increasing. In further tests, I find that firms with environmental initiatives pay abnormally high audit fees. My results are robust to a number of additional tests including partitioning by firm size and environmentally sensitive industries, yearly analyses, potential endogeneity threats, additional control variables, and sensitivity to firms registered with the Global Reporting Initiative (GRI) on Corporate Sustainability Reporting.

Overall, my results support the assertion that auditors appear to consider a client's environmental initiatives in the audit of the financial statements. Assuming that higher audit fees represent greater audit effort (e.g., Davis et al. 1993; O'Keefe et al. 1994; Schelleman and Knechel 2010), my results suggest that auditors recognize and evaluate the financial statement implications of environmental initiatives. Moreover, my results suggest that the extent to which auditors consider environmental initiatives varies according to the types of initiatives and the level of capital expenditures. These findings suggest that auditors are aware of the differential financial implications of environmental initiatives when performing the audit. An important contribution of my study is that I extend the understanding of how strategic initiatives, not previously examined, influence 
financial reporting and the assurance function. Generally, my findings suggest that auditors appear to recognize the increased attention various stakeholders are giving to environmental issues, and the financial implications of clients' strategic environmental initiatives. I complement Simnett et al. (2009a) who examine the choice of assurance providers to a client's stand alone CSR reports. Stand alone CSR reports are voluntary and are not part of the audited financial statements. I develop and test hypotheses that examine the implications of environmental initiatives, a sub-set of CSR activities, on the performance of the external financial statement audit. My results also suggest that future audit fee research may want to consider environmental initiatives and how they manifest in financial reporting when modeling determinants of audit fees because we are in an era of environmental focus characterized by Congressional, regulatory, societal, and capital markets emphasis on such issues, and the call for the accounting profession to respond accordingly.

The remainder of this essay progresses as follows. First, I review relevant extant literature. I, then discuss the sample and empirical model, present my primary and addition analyses results, and finally conclude the paper.

\section{Background and Prior Literature}

Research and theory relating environmental initiatives to the performance of the external audit is virtually non-existent. I, therefore, first review studies that examine the association between financial performance and environmental performance to provide a backdrop to the potential association between environmental initiatives and audit fees. 


\section{Environmental Performance and Financial Performance}

Although corporate environmental performance in the U.S. has not historically received strong emphasis as in other developed nations, the prior literature does support its relation to firm financial performance. Albeit limited, I focus on the U.S. literature as these are the most relevant to my study. ${ }^{5}$ As early as 1972 , accounting research in the U.S. documented a positive association between environmental performance and financial performance in the pulp and paper industry. Bragdon and Marlin (1972) and subsequently Spicer's (1978) empirical archival results showed that firms with better environmental pollution-control devices tended to be larger, more profitable, and have higher price-to-earnings and return on capital ratios.

In the more recent empirical archival studies, the environmental preparedness and performance of firms are significant and positively associated with accounting-based operational and financial performance measures such as return on assets and Tobin's $q$ (Guenster et al. 2006; Semenova and Hassel 2008). As detailed comprehensive data on environmental performance or initiatives is not readily available from public sources, Douglas and Judge (1995) utilize a survey questionnaire method. Responses from U.S. environmental managers indicated that firms with a greater amount of resources and functionality committed to the natural environment experience greater success at integrating environmental issues into the strategic planning process and exhibit superior environmental and financial performance. Collectively, these studies support a link between environmental initiatives and financial performance, which underscores the

${ }^{5}$ Refer to Balabanis et al. (1998), Cronin (2001), and Hill et al. (2007) for a review of selected studies in other countries. 
impact environmental initiatives have on financial reporting. The central premise of these studies is that firms undertake environmental initiatives and allocate resources to these initiatives to achieve their strategic objectives. Because environmental initiatives potentially affect performance, which in turn is related to audit risk, effort, and audit fees (e.g., O’Keefe et al. 1994; Hay et al. 2006), it follows that environmental initiatives could affect the performance of the financial statement audit. However, given the lack of authoritative guidance on auditing environmental initiatives, external auditors may have difficulty evaluating and auditing the financial implications and related economic consequences of environmental initiatives. ${ }^{6}$ Therefore, it is not clear the extent to which auditors would consider environmental initiatives when performing the financial statement audit.

\section{Hypotheses Development}

\section{Environmental Initiatives and Audit Fees}

Dittenhoffer (1995) recommends external auditors be cognizant of potential financial statement implications of the environmental initiatives undertaken by a client. Dittenhoffer (1995) posits that environmental initiatives may have financial reporting valuation and disclosure implications but does not offer specific guidelines. Watson and MacKay (2003) synthesize the literature on corporate environmental policy and audit

${ }^{6}$ For instance, an environmental project that invests in theoretically more advanced pollution-control equipment may be difficult to audit because the actual performance outcome of the equipment is unknown. Such a project could also raise questions regarding the fair value and thus possible impairment of existing equipment and the need to evaluate the financial impact, accounting treatment, and disclosure of the project. These are complex audit issues. For a discussion of the complexity of auditing green-house gas emissions, see Simnett et al. (2009b). 
considerations. They describe the intensifying public and political emphasis on corporate environmental issues but highlight that management's complete discretion over how they disclose information about environmental issues, due to the lack of a standard reporting system, has led to a "greenwashing" effect. They recommend auditors should carefully evaluate managerial assertions about environmental initiatives and their financial implications.

Auditors may give greater attention to environmental initiatives when performing the audit because of (i) increasing Congressional, regulatory, societal, capital market, and the accounting profession's interest in environmental information (e.g., Simnett et al. 2009a; Melancon 2010), and (ii) the impact environmental initiatives may have on management's assertions relating to the financial statements. Auditors could either perform additional audit work themselves or rely on the work of environmental auditors to the extent necessary. ${ }^{7}$ If auditors adopt either approach then the additional assurance work could manifest in a positive association between environmental initiatives and audit fees. $^{8}$

\footnotetext{
${ }^{7}$ Darnell et al. (2009) propose that firms with external, independent environmental auditors may be able to more legitimately signal to the market, regulators, and investors that they are strong environmental performers, potentially improving firm reputation and attractiveness to customers and financers. Simnett et al. (2009b) suggest that financial statement auditors could rely on such experts to help them evaluate management's assertions regarding environmental issues. Currently, there is no data available to ascertain the extent to which financial statement auditors rely on the work of environmental auditors.

${ }^{8}$ I am aware through personal conversations with audit partners and managers of the Big 4 that an audit program on environmental issues is available and used on a case-by-case basis. The extent of audit work performed on environmental issues is contingent on a client's emphasis and activities relating to the natural environment.
} 
Cho et al. (2009) and Simnett et al. (2009b) suggest that the MD\&A section is one forum where management may discuss environmental initiatives, their outcomes, and financial implications. Auditors are required by Statement on Auditing Standards (SAS) 118, Other Information in Documents Containing Audited Financial Statements to evaluate disclosures in the MD\&A (AICPA 2006b). Auditors are required to ensure the information in the MD\&A is consistent with and reconciles with information in the financial statements. The SAS 118 requirements suggest that auditors may incorporate environmental initiatives in the performance of the audit.

Alternatively, auditors may not elevate the importance of environmental initiatives when auditing the financial statements because of the difficulty due to lack of authoritative guidance, experience, and training on auditing environmental initiatives and their consequences (Simnett et al. 2009a; 2009b). Currently there are no statutory requirements or generally accepted verification standards in the U.S. that relate to the preparation, presentation, and verification of environmental or corporate social responsibility data. Consequently, auditors may ignore such information. If auditors choose to ignore environmental initiatives or consider them to be unimportant, I expect environmental initiatives to be unrelated to audit fees.

A client risk perspective also suggests alternative relationships between environmental initiatives and audit fees. Following SAS 109, Auditors are required to obtain an understanding of the nature of the client's business, its business processes and environment, and industry to assess various risks including the risk of a material misstatement (AICPA 2006a). Dittenhoffer (1995) and Simnett et al. (2009a; 2009b) 
urge auditors to give greater consideration to environmental issues because they are integral to a client's strategies, business processes, controls, and the external environment. Auditors can incorporate environmental initiatives when developing their understanding of the client's business and assessing client-related risks. Generally, if management of firms with environmental initiatives is perceived as responsible corporate citizens then it is likely such moral behavior may be considered positively by the auditor. Moral behavior is a function of management integrity and the tone at the top (Schwartz et al. 2005). Higher management integrity and ethical tone at the top may reduce the auditor's assessment of client-related risks and audit effort, which may, ceteris paribus, manifest in lower audit fees (e.g., Carcello et al. 2002). If, however, auditors perceive management is engaging in "greenwashing" then they may ignore environmental initiatives, raise doubts about management's integrity and intentions, and/or consider the likelihood of management misreporting in other areas of the accounts. The latter increased client risk possibility suggests that environmental initiatives may have an upward pressure on audit fees.

Consider a second example where the auditor understands a client's strategy of becoming more environmentally friendly. A client may voluntarily embark on a program of using recycled raw materials and reducing waste in its manufacturing processes to achieve its strategy of becoming "green". Such a strategy may demand replacement and/or modification of current plant and equipment, changes in purchases and inventory processes, controls, and throughput and performance measures. The environmental and account level risks and economic consequences of the preceding may be considered by 
the auditor which could result in additional assurance work. However, if the auditor is unclear on how to evaluate and assess the implications of the environmental initiatives either because of lack of guidance and expertise, or because management is unable to provide clear documentation, then the auditor may ignore the initiatives altogether, rely on the work of an expert, or perform alternative audit procedures. Empirically, the alternative audit and financial reporting consequences of environmental initiatives suggest that it is not clear how the additional audit work related to environmental initiatives might bear out in audit fees. The lack of prior evidence and alternative arguments relating environmental initiatives to audit fees suggest I propose a null hypothesis:

H1: There is no association between environmental initiatives and audit fees.

\section{Types of Environmental Initiatives and Audit Fees}

As an extension to H1, I examine the association between the types of environmental initiatives and audit fees. Currently, I am not aware of any clear guidelines or other documentation discussing how environmental initiatives differ and their financial and reporting implications. Simnett at al. (2009b) argue that environmental issues are very complex and understanding their implications is difficult. As such, I do not specify hypotheses but seek to explore how different types of initiatives are related to the performance of the audit. According to KLD Research \& Analytics, Inc., firms may engage in a range of environmental initiatives that address pollution and climate issues, recycling, environmentally friendly products and services, and other initiatives (KLD 2006). 
Relatively, pollution and climate related initiatives may demand greater economic resources because of the need to acquire new technology and modify existing facilities. Thus, the auditor may need to perform additional audit work to ensure that transactions related to such initiatives are properly accounted for. Recycling initiatives, on the other hand, may not require significant financial resources but more of a cultural change. Hence, recycling programs are not expected to be positively related to audit fees. Environmental initiatives such as producing or selling environmentally friendly products and services may also require significant financial resources as the need for new technology, equipment, and purchase of appropriate production factors may be critical to the success of these initiatives. In addition, the market success of such products and services due to competition and consumer choices could present greater business risks and even threaten the viability of the business as a going concern. Thus, initiatives related to products and services are likely to exert upward pressure on audit fees. Finally, initiatives classified as "other" include management commitment to developing environmentally friendly systems and programs, and other proactive initiatives. Since it is not clear what these initiatives are or how management may use this category to justify their assertions that could be inappropriate, this category may present greater audit risk, and thus be positively associated with audit fees. I explain these initiatives types in greater detail in the Variable sections to follow.

\section{Environmental Initiatives, Capital Expenditure, and Audit Fees}

Environmental initiatives undertaken by a firm require significant resources and management commitment. These initiatives may require significant one-time and/or 
ongoing financial investment. For example, earlier I documented the material capital investments made by ChevronTexaco to achieve its environmental initiatives. In the Appendix, I provide anecdotal examples of environmental initiatives from annual financial reports. While it is relatively clear that environmental initiatives have financial statement implications through capital expenditures, which I empirically address in my second dissertation paper, there is no prior empirical evidence of how capital expenditures are related to audit fees. My search and the comprehensive review of the audit fee literature by Hay et al. (2006) do not identify a single study that examines how capital expenditure is related to audit fees.

Capital expenditure potentially presents an important audit item because it is often materially misstated as firms seek to enhance income by capitalizing operating expenses. High profile cases such as Tyco and WorldCom heightened the awareness of firms misreporting expenses as capital items (Maremont and Cohen 2002; Pulliam and Solomon 2002). The Committee of Sponsoring Organizations of the Treadway Commission (COSO) report that that majority of asset valuation frauds are related to capitalizing items that should be expensed and urge auditors to give greater attention to this pervasive and material reporting problem (Beasley et al. 1999; 2010). Audit Analytics Inc. (2008) identifies capital expenditure as one of the top six categories of restatements, and auditing and fraud textbooks (e.g., Arens et al. 2010; Wells 2008) are also beginning to rate capital expenditure as a high fraud risk account.

The risk of a material misstatement with respect to capital expenditure is expected to increase when coupled with environmental initiatives. This is so because as explained 
earlier, often-times the outcomes and/or success of environmental initiatives is difficult to quantify and thus its environmental and economic consequences are not clear (Watson and MacKay 2003; Simnett et al. 2009b). Environmental initiatives may require significant amounts of financial investment which could place pressure on management's ability to meet earnings targets. Under such circumstances, management may resort to intentionally capitalizing operating expenses when it may not be appropriate. Given the ambiguity and risks surrounding the accounting treatment of expenditures related to environmental initiatives, I posit that relative to firms without environmental initiatives, firms with environmental initiatives may require greater audit scrutiny in increasing capital expenditure.

H2: The positive association between environmental initiatives and audit fees, if any, is more pronounced when the level of capital expenditure is higher.

\section{Sample and Research Design}

\section{Sample}

To proxy for a client's environmental initiatives, I rely on the KLD Research \& Analytics, Inc database to identify firms with environmental data. KLD independently rates companies trading on U.S. stock exchanges with regard to their social performance across a range of dimensions, including the environment. ${ }^{9}$ The KLD database is widely used and considered highly reliable because the KLD analysts are independent of the companies being rated, the analysts use objective screening criteria to rate firms, the

\footnotetext{
${ }^{9}$ Other dimensions of social performance data in KLD include community, diversity, employee relations, and human rights (KLD 2006).
} 
ratings are applied consistently across companies, and a wide range of sources is used to obtain the data (Waddock and Graves 1997; Hillman and Keim 2001). ${ }^{10}$ This database, containing firm data as far back as 1991, has been increasingly used in the past several years in management and accounting research (e.g., Cho et al. 2006; Bartkus and Glassman 2008; Sharfman and Fernando 2008; Chen et al. 2008, Cho et al. 2009).

I begin my data year in 2004 since KLD restructured some of its data in prior years thus affecting comparability. My initial sample comprises 9,012 firm observations in calendar years 2004-2006. I then obtain financial, fee, and corporate governance data for these observations from COMPUSTAT, Audit Analytics, and the Corporate Library databases, respectively. After converging these databases with KLD, my sample reduces to 3,697 observations. I exclude 12 financial firms based on two-digit standard industry classification ( $\mathrm{SIC}=60$ to 69$)$ and a further 1,211 observations without a December 31 year-end because KLD gathers and codes environmental data on a calendar-year basis. This final criterion is critical because failure to match the data years correctly can lead to inaccuracies in the analyses. My final sample comprises 2,474 firm observations with all the necessary data.

\section{Empirical Models and Variables}

I construct my audit fee model based on the audit-fee literature meta-analysis by Hay et al. (2006) and more recent audit fee studies (e.g., Ettredge et al. 2007; Kealey et al. 2007; Hogan and Wilkins 2008; Venkataraman et al. 2008; Vermeer et al. 2008; Hay and Knechel 2010). For Hypothesis 1, I estimate Equation 1 to examine the association

\footnotetext{
${ }^{10} \mathrm{KLD}$ indicated through our discussions that most of the environmental data are sourced from a firm's proxy statements such as the $10-\mathrm{K}$.
} 
between environmental initiatives (ENV_IN) and audit fees. For Hypothesis 2, I estimate Equation 2 that introduces the interaction term between environmental initiatives and capital expenditure. The variables in my regression models are explained below. All my regressions are performed on data winzorised at the 1 percent and 99 percent levels and the standard errors are adjusted for heteroskedasticity (White 1980). ${ }^{11}$

$\begin{array}{cc}\text { LNAUDFEE }= & f \text { LNASSETS, IND_ES, SEGNUM, FOREIGN, INVAR, LOSS, } \\ & \text { LEV, BDSIZE, BDMTGS, BDINDEP, BIG4, LNNAS, } \\ & \text { ZSCORE, GROWTH, INITIAL, SPECIAL, ENV_IN, } \\ & \text { YEAR FIXED EFFECTS }\} \\ & \\ \text { LNAUDFEE }= & f\{\text { LNASSETS, IND_ES, SEGNUM, FOREIGN, INVAR, LOSS, } \\ & \text { LEV, BDSIZE, BDMTGS, BDINDEP, BIG4, LNNAS, } \\ & \text { ZSCORE, GROWTH, INITIAL, SPECIAL, EI_YN, } \\ & \text { LNCAPEX, EI_YN*LNCAPEX, YEAR FIXED } \\ & \text { EFFECTS }\}\end{array}$

Dependent Variable: Audit Fees

Consistent with the prior audit fee literature, I use the natural logarithm of audit fees paid to the external auditor as my dependent variable (LNAUDFEE). In additional analyses, I estimate an abnormal audit fee model to determine whether clients with environmental initiatives pay abnormally higher audit fees.

\section{Test Variable H1: Client Environmental Initiative}

The KLD database provides information on environmental initiatives undertaken by a firm. For each of the five initiatives rated by KLD, a firm is designated a binary variable ( 1 if an initiative is reported, 0 otherwise) to indicate if the firm is involved in that specific environmental initiative. I first analyze the effect of overall environmental

\footnotetext{
${ }^{11}$ My results are consistent if I use non-winzorised data and estimate standard and robust OLS regressions.
} 
initiatives (ENV_IN) which represents the sum of five different initiatives. The sum measure has been widely used in prior research and represents the extent of environmental initiatives undertaken by a firm (e.g., Waddock and Graves 1997; Hillman and Keim 2001). ${ }^{12}$ To provide insight, I perform further analysis based on types of initiatives.

The first initiative type relates to a company's use and/or development of environmentally beneficial products or services, such as innovative remediation products and energy efficient processes (PROD_SERV). The second applies to a company having notably strong pollution prevention programs, such as emissions and toxic-use reductions (POLL_PREV). The third refers to a firm which is a substantial user of recycled materials, or is a major factor of the recycling industry itself (RECYCLE). The fourth initiative type indicates that a company has demonstrated a commitment to climatefriendly practices in order to reduce its impact on climate change and pollution; such measures include energy efficiency and the use of renewable energy and clean fuels (CLIMATE). Finally, the fifth environmental initiative type in my data indicates a company's superior commitment to management systems, voluntary programs, and other environmentally proactive activities (OTHER). I note here that beginning the year 2006, KLD rated one additional environmental variable, ISO 14000 certification. However, since my data covers 2004-2006, I exclude this variable from my primary analysis but perform a separate analysis for 2006 after including this additional variable.

\footnotetext{
12 Prior research equally ranks each component of the KLD environmental ratings because there is no theoretical basis for a ranking (Hillman and Keim 2001). Accordingly, I do not attempt to rank the environmental initiatives.
} 


\section{Test Variable H2: Interaction of Environmental Initiative and Capital Expenditure}

For the test of Hypothesis 2, the interaction effect of environmental initiatives and capital expenditure on audit fees, I use the natural logarithm of capital expenditures (LNCAPEX) and a categorical environmental initiative variable (ENV_YN). I obtain the capital expenditure for a firm in a given year from COMPUSTAT. The categorical environmental initiative variable is determined by setting ENV_YN to 1 if KLD reports a firm has at least one environmental initiative, and 0 otherwise. I then take the product of LNCAPEX and ENV_YN to derive the interaction term.

\section{Control Variables}

Based on the prior audit fee literature, I include variables determined to be significantly related to audit fees. ${ }^{13}$ I include firm size (LNASSETS $=$ the natural logarithm of total assets), the number of business segments (SEGNUM), and foreign operations (FOREIGN $=1$ if firm has foreign operations, and 0 otherwise) because the prior literature suggests firm complexity due to size, more business segments, and foreign operations are associated with higher audit fees. I include leverage (LEV $=$ ratio of total debt to total assets) because of greater assurance required for firms with more debt. I include INVAR, LOSS, and ZSCORE because firms with greater inventory and accounts receivable in total assets, loss-generating firms, and firms in financial distress present higher risk and put an upward pressure on audit fees. INVAR is calculated as the sum of inventory and accounts receivable standardized by total assets, LOSS equals 1 for firms

13 Some of my control variables also help address potential spurious effects as they could affect the likelihood of a firm engaging in environmental initiatives. These variables include firm size, leverage, financial performance (loss, zscore), and board variables (see Tests for Endogeneity under the Additional Analyses section). 
reporting a loss for the financial year, and 0 otherwise, and ZSCORE is the Zmijewski financial distress score. Since the prior literature reports that firms with high growth present greater risk of internal control breakdowns and financial misreporting, I control for GROWTH (percentage growth in sales for the year). The final firm financial variable I control for is special items (SPECIAL $=$ special items scaled by total assets) because such items also present greater risk and require additional audit effort.

I include three firm governance control variables because they are related to audit fees as follows (e.g., Carcello et al. 2002; Hay et al. 2006). Firms with larger boards have access to greater resources and thus may be better able to reduce risks facing the firm. However, larger boards can also lead to inefficient monitoring thus increasing risks. Therefore, board size (BDSIZE $=$ the number of directors on the board) can be positively or negatively related to audit fees. I include board independence (BDINDEP is the proportion of independent directors on the board) because greater board independence reduces agency costs and the risk of misreporting. Alternatively, independent directors may demand additional assurance from the auditor to protect their reputation. Such effects suggest a positive or negative association between BDINDEP and audit fees. My third governance variable is the number of board meetings (BDMTGS is the number of board meetings during the financial year) because boards that meet often are arguably more diligent in identifying and addressing problems, and interacting with the auditor. Thus, board meetings can be positively or negatively related to audit fees.

I include three auditor-related variables, BIG4, LNNAS, and INITIAL. I include a Big 4 auditor indicator variable because prior research shows that Big 4 audit firms 
provide higher quality audits and also tend to charge higher fees (BIG $4=1$ if auditor is a Big 4 firm, 0 otherwise). I control for the level of non-audit fees (LNNAS = natural logarithm of the non-audit fees paid to the auditor) because firms may employ their auditor to conduct environmental audits or provide assurance on sustainability reports (Simnett et al. 2009a). As these audits are voluntary and not part of the financial statement audit, the fees for such audits would be captured in non-audit fees. I also include an indicator variable of a first year audit (INITIAL $=1$ if auditor is in the initial year of the audit, and 0 otherwise) as audit fees in the initial year may be higher due to greater diligence required, or lower due to audit pricing to entice new clients. My final control variable is IND_ES, a dichotomous variable capturing firms operating in an environmentally-sensitive industry as defined in Cho et al. (2006). These industries include oil exploration, paper, chemical and allied products, pharmaceuticals, petroleum refining, and metals industries. As my data is from 2004 to 2006, I include year fixed effects. For efficient reference, the operational definition of the variables, their expected association with audit fees, and data sources are summarized in Table 1.

\section{Results}

\section{Descriptive Statistics}

Table 2 presents the descriptive statistics on environmental initiatives for the full sample and by environmentally sensitive industries and non-environmentally sensitive industries. I present five categories of environmental initiatives and the total number of initiatives; the total represents the ENV_IN variable. Of the total sample observations of 2,474, there are 327 observations (13.2\%) of environmental initiatives (ENV_IN). The 
majority of the initiatives relate to CLIMATE $(n=110)$ followed by PROD_SERV $(n=$ 67), OTHER $(\mathrm{n}=57)$, POLL_PREV $(\mathrm{n}=54)$, and RECYCLE $(\mathrm{n}=39)$. Not surprisingly, the proportion of environmental initiatives is greater across all categories in the environmentally sensitive industries, and all categories but one, CLIMATE, are significantly different.

Table 3 presents the descriptive statistics for my dependent and control variables for the full sample and by sub-samples of firms that have at least one environmental initiative $\left(\mathrm{ENV}_{-} \mathrm{IN}>0\right)$ and those that do not have any environmental initiatives $\left(E N E_{-} I N=0\right)$. I find that the average audit fees are significantly $(\mathrm{p}<0.01)$ higher for firms with at least one environmental initiative compared to firms without an environmental initiative. I also find that capital expenditure is also significantly larger ( $p$ $<0.01$ ) in the environmental initiative sub-sample. Regarding my control variables, firms with at least one environmental initiative appear to be significantly larger and less leveraged. On average, these firms have less negative Z-scores, greater number of business segments, and a higher propensity to operate in an environmentally sensitive industry, and in foreign markets. Firms with at least one environmental initiative also have boards that are larger, more independent, and meet more frequently. Finally, with regard to audit variables, a greater (lower) proportion of firms engaging in environmental initiatives have a Big 4 auditor (initial audit) and these firms also procure more non-audit services from the auditor. All of the differences above are highly significant $(p<0.01)$ and suggest that characteristics of firms with at least one environmental initiative vary significantly from firms without an environmental initiative. 


\section{Multivariate Analyses}

Table 4 reports Pearson and Spearman correlation matrices for the independent variables. One correlation, between LNASSETS and LNCAPEX, is significant and large (0.86) but is not surprising because capital expenditure is a material component of assets. However, there is no multicollinearity threat from this association because when I include both these variables in my capital expenditure interaction tests, LNASSETS is based on the value of total assets after excluding capital expenditures. The Pearson (Spearman) correlation between LNCAPEX and LNASSETS excluding capital expenditures is -0.51 $(-0.53)$. All other correlations are below multicollinearity threat thresholds, the highest correlation being 0.58 between LNASSETS and LNNAS. All of the reported and untabulated variance-inflation-factors (VIF) are below the threshold of 10, beyond which multi-collinearity may be a problem (Kennedy 1992).

Table 5 presents the results for the regression of audit fees on the controls and my test variable, ENV_IN. The results for the control variables indicate that LNASSETS, SEGNUM, FOREIGN, INVAR, LEV, BDMTGS, BDINDEP, BIG4, LNNAS, ZSCORE, and SPECIAL are positive and significantly associated with LNAUDFEE. INITIAL and GROWTH are negatively associated with LNAUDFEE. I find that IND_ES is negatively associated with LNAUDFEE suggesting that firms in environmentally sensitive industries pay relatively less audit fees than firms not in such industries. This is probably because of special regulatory scrutiny (e.g., EPA) of firms in environmentally sensitive industries. Most importantly, the results indicate a highly significant positive association between my test variable, ENV_IN, and LNAUDFEE. Hypothesis 1 is therefore rejected. 
This finding suggests that environmental initiatives affect the performance of the audit in that auditors appear to consider environmental initiatives in the audit of the financial statements. By expending additional effort, auditors may be providing assurance over a client's assertions regarding environmental initiatives and how they affect the financial statements. This finding supports the profession's recognition of increased market reliance on environmental information when making investment decisions and the need for auditors to modify year-end audit work accordingly.

Table 6 presents my examination of an environmental initiative variable that captures whether a firm is reported by KLD to have engaged in at least one environmental initiative $\left(\mathrm{ENV}_{-} \mathrm{YN}\right)$. I find that $\mathrm{ENV}_{-} \mathrm{YN}$ is positive and significantly associated with LNAUDFEE $(p=0.000)$. This finding suggests that even if a firm is involved in one environmental initiative, there are audit fee implications. The control variable results are similar to those in Table 5.

Also in Table 6, I present evidence of how each type of environmental initiative is related to audit fees. I find that three types of environmental initiatives, PROD_SERV, POLL_PREV, and OTHER are positive and significantly associated with LNAUDFEE. These findings suggest that the positive association between audit fees and environmental initiatives is largely driven by initiatives involving the use and/or development of environmentally beneficial goods and services (PROD_SERV), the implementation of strong pollution prevention programs (POLL_PREV), and a superior commitment to management systems, voluntary programs, and other environmentally proactive activities (OTHER). 
An analysis of the economic or practical significance of the types of environmental initiatives suggests that the statistically significant initiatives, environmentally-friendly products and services, pollution prevention, and other environmentally proactive systems, programs, and activities, will incur on average additional audit fees of approximately $\$ 373,000, \$ 505,000$ and $\$ 421,000$ compared to firms that do not have these initiatives. However, if a firm has at least one initiative, regardless of what type it is, then the impact on audit fees is not cumulative. Our dummy variable results $(\mathrm{ENV}$ _YN) suggest that audit fees are higher on average by about $\$ 357,000$ for firms with an initiative compared to firms without any initiative. To complement this, I also analyze the economic importance of the continuous measure of environmental initiative participation (ENV_IN). The analysis here suggests that when there is a one unit (one standard deviation) change in the natural logarithm of environmental initiatives, audit fees increases by about $11 \%$. Based on the average audit fee, this suggests that audit fees would increase by about $\$ 212,000$. Overall, these analyses suggest that environmental initiatives are economically important determinants of audit fees

Results for the test of $\mathrm{H} 2$ are presented in Table 7. I present two regression results. The first regression includes the environmental initiative variable that captures whether a firm is reported by KLD to have engaged in at least one environmental initiative $\left(\mathrm{ENV}_{-} \mathrm{YN}\right),{ }^{14}$ and capital expenditures $(\mathrm{LNCAPEX}=$ natural logarithm of

\footnotetext{
${ }^{14}$ I employ a binary variable instead of a continuous variable when performing the interaction test related to H2 because Aiken and West (1991) recommend doing so minimizes statistical problems such as multicollinearity and enables better interpretability of interaction effects.
} 
capital expenditures). I modify the firm size variable (LNASSETS) to exclude capital expenditures. In the second regression, I introduce the interaction term, ENV_YN*LNCAPEX.

The first regression shows that both ENV_YN and LNCAPEX are positive and significantly associated with LNAUDFEE $(p=0.000)$. In the second regression I observe the interaction term, ENV_YN*LNCAPEX, is also positive and significantly associated with LNAUDFEE $(\mathrm{p}=0.000)$. This result is consistent with $\mathrm{H} 2$ and suggests that audit fees are increasing in firms with environmental initiatives and greater level of capital expenditure. I also perform interaction tests for each type of environmental initiative and find significant positive interactions for PROD_SERV $(p=0.000)$, POLL_PREV $(p=0.089)$, and CLIMATE $(p=0.000)$.

\section{Additional Tests}

\section{Firm Size}

I test the sensitivity of my primary results to client size as larger firms are more visible and thus subject to greater scrutiny and pressure to implement environmental initiatives. Larger firms also have potentially more resources to invest in environmental initiatives. I partition my sample into small and large firms based on the median of LNASSETS as my cutoff (large firms $>$ median). For the large firm subsample, ENV_IN is significant at the five percent level, and for the small firm subsample, ENV_IN is significant at the ten percent level. When I perform this size sensitivity analysis by initiative type, my results are consistent with those in Table 6 for large firms. For smaller firms, I find that only CLIMATE is significant $(\mathrm{p}<0.01)$. For the test of H2, I find the 
interaction term EI_YN*LNCAPEX is significant for small firms only. The insignificance for large firms could be due to little variability in their capital expenditure and environmental initiatives because large firms are more visible and subject to greater market and regulatory scrutiny.

\section{Environmentally Sensitive Industries}

In order to examine the sensitivity of my results to environmentally sensitive industries, I partition my sample into firms operating in and not operating in such industries. This is an important additional test because my descriptive statistics in Table 2 show that environmental initiatives differ between environmentally sensitive and nonsensitive industries. My untabulated results of re-estimating Equation (1) for both sets of firms show that ENV_IN is positive and significantly $(\mathrm{p}<0.05)$ associated with LNAUDFEE for both sets of firms. I find similar results for the types of environmental initiatives with the following exceptions: CLIMATE is significant for environmentallysensitive firms, and PROD_SERV is not significant for non-environmentally sensitive firms. The former result is not surprising because environmentally sensitive firms face greater scrutiny over climate-related issues of which the auditor is cognizant whereas for non-environmentally sensitive firms, it appears that the development of environmentally beneficial products and services may not have material financial statement implications. When I reperform the test of $\mathrm{H} 2$ for environmentally sensitive and non-sensitive industries separately, I obtain results consistent with those reported in Table 7. 


\section{Yearly Analyses}

I test the sensitivity of my primary results to the financial year examined. As previously noted, my sample covers years 2004 to 2006 . I conduct my regression analysis for each year individually and find results consistent with my earlier results. Obtaining the same results between my pooled and yearly analyses suggests regression bias in my panel data is negligible. In my primary tests, I excluded an additional environmental initiative variable, ISO 14000 certification, that KLD began rating in 2006. When I re-estimate my equations for the entire sample and only for 2006 after including this additional environmental variable, I find results consistent with those in Tables 5, 6, and 7. In the environmental type analysis as per Table 6, I find this variable is positive and significantly related to audit fees $(\mathrm{p}<0.01)$.

\section{Abnormally High Audit Fee}

In order to examine if firms engaging in environmental initiatives pay abnormally high audit fees, I first exclude the environmental variables from my primary audit fee model (Equation 1) and estimate the audit fee model to obtain the residuals. Residuals from audit fee models have been used to proxy for abnormally high audit fees (e.g., DeFond et al. 2002). I then regress these residuals on the environmental initiative variables in order to assess if firms with environmental initiatives are associated with greater than expected annual audit fees. In untabulated results, I observe ENV_IN is positive and significantly associated with the audit fee residuals $(\mathrm{p}=0.000)$. When I repeat the analysis for each type of environmental initiative, I find results consistent with those in Table 6. I obtain similar results when I repeat the interaction test in Table 7 
using abnormal audit fees as the dependent variable. These results are consistent with, and complement my primary findings.

\section{Test for Endogeneity}

In order to rule out concerns of potential endogeneity between environmental initiatives and audit fees, I perform the Hausman test (Hausman 1978; Kennedy 1992). The first procedure of my test requires the estimation of a model for determinants of environmental initiatives (ENV_IN). Calling upon several studies in this limited research area, I include the following potential explanatory variables: size (natural logarithm of total assets) (Spicer 1978; Guenster et al. 2006; Clarkson et al. 2008); leverage (total debt to total assets) (Clarkson et al. 2008); environmentally sensitive industry membership (Cho et al. 2006); board characteristics (size, percentage of independent directors, and meeting frequency) (Kassinis and Vafeas 2002; Webb 2004); profitability (return on assets) (Spicer 1978; Guenster et al. 2006; Clarkson et al. 2008); duality (CEO is the chair of the board) (Webb 2004); the percentage of institutional ownership (Mahoney and Roberts 2007); and finally, the number of environmental concerns. KLD reports dichotomous data on firm environmental concerns, which I use to derive an environmental concern test variable. ${ }^{15}$ While this last variable has not been examined in the prior environmental literature, I believe that the presence of an environmental concern (e.g., oil spill) will increase the firm's need to address such concerns and others through

\footnotetext{
${ }^{15}$ The six environmental concerns are firms: having large hazard waste liabilities or violations of waste management regulations, having violations of air, water, or other environmental regulations, being identified as one of the top manufacturers of ozone-depleting chemicals, having high legal levels of toxic chemical emissions into the air and water, being identified as a substantial producer of agricultural chemicals, having substantial direct or indirect revenues from the sale or combustion of coal or oil and its derivative fuel products, and having involvement in any other environmental controversy (KLD 2006).
} 
the implementation of environmental initiatives. From the estimate of this environmental initiative model, I use the resulting residuals as an explanatory variable in the audit fee model. Since the residual is not statistically significant $(p>0.10)$ in the audit fee model, there is no evidence to suggest potential endogeneity problems (Kennedy 1992).

\section{Potentially Omitted Variables}

In my tests I have sought to maintain parsimony, but a downside is the omission of potentially omitted variables. I perform additional tests to consider potentially omitted explanatory variables. I include the presence of an internal control weakness since my data is post-Section 404 (Raghunandan and Rama 2006; Hogan and Wilkins 2008; Hoitash et al. 2008; Mitra 2009), duality (CEO is the chair of the board) (Muniandy 2007; Mitra et al. 2007; Boo and Sharma 2008), presence of a merger or acquisition within the financial year (Hogan and Wilkins 2008; Hoitash et al. 2008; Ghosh and Pawlewicz 2009), institutional ownership (Hay et al. 2006; Mitra et al. 2007; Hay et al. 2008; Han et al. 2009), and audit committee size and the presence of an accounting expert on the audit committee (e.g., CPA, CFO as defined in Dhaliwal et al. 2010b). I find only internal control weakness $(\mathrm{p}<0.01)$ and merger and acquisitions $(\mathrm{p}<0.10)$ are significant. More importantly, the inclusion of these additional control variables does not affect the results of my environmental initiative variables.

I address next the effect of environmental concerns two ways; first by including it as a control variable and second, by estimating my fee models only for companies that do not have any environmental concern. KLD also provides data on whether a firm violates any environmental standard such those regulated by the EPA. Firms that are subject to an 
EPA citation may remediate the violation and also undertake other voluntary initiatives. When I include either the number of environmental concerns, types of concerns, or whether a firm is reported to have a concern either in the current or prior year, I find that none of these variables is statistically significant in any of my audit fee tests. More importantly, I find my environmental initiative variables remain statistically significant. My results are consistent when I exclude firms with an environmental concern and reestimate the audit fee regressions. ${ }^{16}$

Finally, I consider the effect of the presence of companies in my sample that are registered with the Global Reporting Initiative (GRI). U.S. companies part of the GRI issue a standalone corporate sustainability report that may or may not be assured (Simnett et al. 2009a). These firms are more likely to engage in environmental initiatives and thus their presence in the sample could affect my results. I conduct two tests to evaluate the effects of GRI companies in my sample. ${ }^{17}$ First, I include a control variable for GRI which is equal to 1 for firms in the GRI, and 0 otherwise. Second, I exclude these companies from the sample and re-perform all my tests. My results are not affected when I consider GRI companies. I do find that the GRI control variable is positively associated with audit fees. This observation resonates my results regarding the association between environmental initiatives and audit fees.

\footnotetext{
${ }^{16}$ The sample size for tests excluding companies with an environmental concern is 1,928.

${ }^{17}$ My sample comprises 119 (4.8\%) observations in the GRI.
} 


\section{Conclusion}

Companies are responding to mounting pressures and interest in environmental accountability from a range of stakeholders including Congress, regulators, society, investors and more recently, the accounting profession. To appease these stakeholders, management of companies has responded by investing in environmental initiatives and providing related disclosures in the MD\&A and other sections of the annual report (Form 10-K). However, the credibility of environmental disclosures has been questioned (e.g., Cho et al. 2009) and some suggest that the external auditor can enhance management's assertions regarding environmental disclosures and their implications on the financial statements (Simnett et al. 2009a). While it appears that auditors do not seem to assure the credibility of such disclosures, recent research and the profession has called for greater auditor involvement because auditors are experienced assurance providers (Simnett et al. 2009a; 2009b; Melancon 2010).

This study provides the first empirical evidence of the auditor's potential involvement in providing assurance over a client's assertions regarding the implications of environmental initiatives on reported financial information by examining the association between environmental initiatives and audit fees. If auditors consider the need for additional assurance work in order to substantiate assertions clients make about environmental initiatives and their impact on the financial statements, I would anticipate a positive association between environmental initiatives and audit fees. A result to the contrary may suggest auditors consider environmental initiatives are not material to 
warrant additional assurance, they may lack the expertise to do so, or it is difficult to evaluate the initiatives and their economic and financial implications.

My results suggest auditors appear to consider client environmental initiatives when performing the annual financial statement audit. I find that this association is driven by environmental initiatives regarding the use and/or development of environmentally beneficial goods and services, the implementation of strong pollution prevention programs, and a superior commitment to management systems, voluntary programs, and other environmentally proactive activities. My results imply that these environmental initiatives may require material financial resources that have financial reporting implications. Regulation of climate related initiatives by authoritative agencies such as the EPA could explain the non-significant finding for this variable. Recycling initiatives could be considered not financially material as this may not require significant investment in resources but more of a corporate cultural change. Future research with more specific data using both empirical archival and survey methods could provide more definitive interpretation of my results. Nevertheless, my results imply that auditors appear to recognize the increased market reliance on corporate environmental information and the demand this places on the annual financial statement audit.

An interesting finding is that audit fees are increasing for clients with an environmental initiative and higher capital expenditure. By documenting this conditional effect, I provide empirical evidence that extends our understanding of the implications of a client's strategic orientation on the financial statements and the production of the audit. Very little research, if any, has investigated how a client's strategy is related to audit fees 
(Allen et al. 2006). In this context, my specific findings show that environmental initiatives as a business strategy demands resources which have financial reporting implications (e.g., need for financing, capitalizing or expensing outlays). I examine this notion specifically in my second dissertation paper. My findings are also consistent with capital expenditure being a high risk account and the potential for management to engage in "greenwashing" environmental information. Taken together, my results suggest auditors appear to be cognizant of such risks.

Some potential limitations of my study provide opportunities for future research. First, my environmental initiative data does not provide information on the likely success of the initiative, nor does it capture the extent of the financial investment related to a particular initiative. Such information, however, would be made available to auditors, as they would need specific information to evaluate management's assertions regarding these initiatives. The availability of such data would provide greater analytical and inferential insight on how environmental initiatives affect the audit. Second, I do not examine whether auditors are able to identify "greenwashing" and how these influence the audit. The experimental method may be more suited to such an examination. Third, I do not examine the incentives facing management to engage in environmental initiatives and how these affect the association between initiatives and audit fees. Fourth, as with any empirical examination, I can only provide evidence of an association but cannot make inferences with respect to causation. Fifth, while my results are robust to a comprehensive set of control variables and additional tests, I cannot rule out the presence of other potential omitted correlated variables not yet uncovered in extant audit fee 
literature. Lastly, while this dissertation paper addresses environmental initiative implications for the auditor, many stakeholder perspectives may be examined, opening the door for much future research.

\section{ENVIRONMENTAL INITIATIVES AND CAPITAL EXPENDITURES}

This study provides initial and timely evidence on the association between a firm's environmental initiatives and capital expenditures. As I have discussed, the past twenty years have seen an unprecedented market growth in socially responsible mutual funds and market indices, with investments growing exponentially from $\$ 639$ billion to \$3.07 trillion between 1995 and 2010 (Social Investment Forum 2010). These growth figures underscore the fact that investors are placing more emphasis on socially responsible companies. Corporate regulators such as the Securities and Exchange Commission (SEC) parallel such market emphasis through their oversight activities, such as the aforementioned recent guideline issued on environmental disclosure aimed at ensuring investors receive adequate and transparent disclosure on a firm's environmental activities and risk (SEC 2010). This guidance amplifies the operational and financial risks associated with environmental initiatives and specifically cites the significant effect such initiatives may have on capital expenditures (SEC 2010).

However, we do not know if and how environmental initiatives are related to capital expenditures since there is no prior empirical research. I fill this void in the literature and extend my knowledge about the financial implications of environmental initiatives. Understanding the relationship between environmental initiatives and capital 
expenditures is important for several reasons. First, capital expenditures are pivotal to achieving corporate objectives and excess market returns (e.g., Tobin 1969; Yoshikawa 1980; Hayashi 1982; Abel 1983). In a climate where environmental initiatives are receiving heightened attention and attracting investment capital and government grants and subsidies, firms may tout their environmental strategies but fail to invest secured funding in such strategies. Bohn reports that such fraudulent practices are on the increase with significant economic consequences for investors, lenders and the government (2010). Examining the empirical relationship between environmental initiatives and capital expenditures could inform and help address such concerns.

Second, since capital expenditures comprise a significant portion of a firm's assets which are utilized to achieve its objectives, understanding the association between environmental initiatives and capital expenditures could advance our knowledge of how environmental initiatives are implemented by companies. Often times, a firm's growth is measured through growth in total assets, and knowing how environmental initiatives affect firm growth in an era of environmental concerns could assist investors and analysts in making more informed decisions.

Third, because of the uncertainty related to the outcomes of environmental initiatives, management may be motivated to deal with the associated operational and financial risks by manipulating the disclosure of outlays on environmental matters, particularly treating the outlays as capital rather than an expense. Capital expenditure is one of the riskiest accounts that has been subject to material restatements and financial fraud (e.g., Beasley 1999; 2010; Maremont and Cohen 2002; Pulliam and Solomon 2002; 
Audit Analytics Inc. 2008). Auditors, analysts, investors, and regulators can benefit from an understanding of how capital expenditures are influenced by environmental initiatives.

In this study, I address two research questions. First, I address the extent to which a firm's environmental initiatives factor into its capital expenditure decisions. I empirically test this by regressing capital expenditures on environmental initiatives. My second research question facilitates understanding of how types of environmental initiatives are related to capital expenditures. This is an important issue because environmental initiatives can vary in complexity and demand on financial resources. I empirically address this question by regressing capital expenditures on five specific types of environmental initiatives.

Using a sample of 2,164 observations from 2004 to 2006 and after controlling for other determinants of capital expenditures, I find a significant positive association between environmental initiatives and capital expenditures. I also find this significant positive association persists across all five types of initiatives, but is strongest for initiatives related to recycling, climate, and other initiatives (management systems, voluntary programs, and other environmentally proactive activities). In further tests, I find that firms with environmental initiatives have abnormally high capital expenditures. My results are also robust to a number of additional tests.

Overall, my results are consistent with the assertion that firms undertaking environmental initiatives support such initiatives with increased investments in capital expenditures. In addition to filling a gap in the literature, the findings can assist analysts, auditors, investors, regulators, and others interested in understanding the financial 
implications of a firm's environmental initiatives. My results suggest that the economic impact of environmental initiatives on capital expenditures is not constant but varies according to the type of initiative. My initial results present an opportunity to delve deeper and further into our understanding of why, how, and when environmental initiatives may have different financial implications.

The remainder of this dissertation paper progresses as follows. In the next section, I review pertinent extant literature. I, then, discuss the sample and empirical model, followed by my primary and additional analyses results, and lastly, I conclude the paper.

\section{Background and Prior Literature}

I review two paradigms of pertinent literature to underpin potential associations between environmental initiatives and capital expenditures. I first review studies that examine the association between environmental performance and financial performance, as I did for my first dissertation essay. The purpose of this review is to provide some background and imply a link between environmental initiatives and capital expenditures. The second paradigm I review is the limited literature on the determinants of capital expenditure so that I can develop a baseline model and subsequently evaluate the contribution of environmental initiatives in explaining capital expenditures.

\section{Environmental Performance and Financial Performance}

Although environmental performance has not historically received the same level of attention in the U.S. than it has in other developed nations, prior U.S. studies do support a relation between corporate environmental performance and financial 
performance. I focus on the U.S. literature as these are the most relevant to my study. ${ }^{18}$ As early as 1972, accounting research in the U.S. documented a positive association between environmental performance and financial performance in the pulp and paper industry. Bragdon and Marlin (1972) and subsequently Spicer's (1978) empirical archival results showed that firms with better environmental pollution-control devices tended to be larger, more profitable, have higher price-to-earnings and return on capital ratios. These positive associations between firm environmental performance and favorable financial outcomes support the notion of a corporate incentive to invest in environmental capital expenditures as a means of producing stronger financial results.

Douglas and Judge (1995) report survey responses from U.S. environmental managers that indicate firms with more resources functionality committed to the natural environment experience greater success at integrating environmental issues into the strategic planning process and, consequently, exhibit superior environmental and financial performance.

More recent studies reveal that firms with greater environmental preparedness and performance are significantly and positively associated with higher levels of accountingbased operational and financial performance measures such as return on assets and Tobin's $q$ (Guenster et al. 2006; Semenova and Hassel, 2008). Collectively, the studies reviewed support a positive link between environmental initiatives and financial performance, which underscores a potential motivation for firms to increase capital investments in order to participate in such initiatives.

\footnotetext{
${ }^{18}$ Refer to Balabanis et al. (1998), Cronin (2001), and Hill et al. (2007) for a review of selected studies in other countries.
} 


\section{Determinants of Capital Expenditures}

The motives for a firm's capital investment decisions have been predominantly studied from a market perspective. Achieving greater returns and firm valuations are the primary documented incentives for capital expenditures (Tobin 1969; Yoshikawa 1980; Hayashi 1982; Abel 1983). Most recently and relevant to my work, some studies examine firm characteristics as potential determinants of various capital investment qualities, such as sensitivity and efficiency (Biddle and Hilary 2006; Hovakimian 2009; Biddle et al. 2009).

Biddle and Hillary (2006) find that higher quality accounting enhances investment efficiency by reducing information asymmetry between management and independent capital suppliers, with this effect being stronger in economies with primarily arm's length financing relative to countries where creditors supply more capital. Hovakimian (2009) finds investment sensitivity varies due to financial constraints, cash flows, and growth opportunities. Finally, Biddle et al. (2009) suggest that higher reporting quality improves investment efficiency by reducing friction, such as adverse selection and moral hazard, because higher financial reporting quality is associated with better access to external financing.

\section{Hypotheses Development}

\section{Environmental Initiatives and Capital Expenditures}

A firm's commitment to successfully undertaking environmental initiatives congruent with its strategic intent demands substantial investments in financial and nonfinancial resources. The resource demands span across the organization, from top 
management to employee training and education, from systems development to policy implementation, from marketing research to product design and process reengineering, refitting and retooling production and service delivery equipment and buildings. These resource demands suggest capital expenditures are an important and material item that could affect the outcomes of environmental initiatives. Such an implication has been supported by both financial regulation and anecdotal evidence. For example, the SEC's recent environmental disclosure interpretation addressing climate change specifically cites the imperative for firms to consider the impact of its environmental initiatives on capital expenditures when constructing its financials and related disclosures (SEC 2010). Additionally, under Item 101 of Regulation S-K, material current and future capital expenditures made for environmental controls over greenhouse gas emissions are required to be considered and disclosed.

My search of the business press and proxy statements filed with the SEC provides anecdotal evidence supporting the capital expenditure implications of environmental initiatives. For example, ChevronTexaco Corporation's Business and MD\&A sections of the $10-\mathrm{K}$ discuss that its environmental projects associated with increasing air and water quality required financially material capital expenditures of $\$ 145$ million in 2004 (ChevronTexaco 2004). The company's total environmental capital expenditures continued to grow significantly between 2004 and 2006, from $\$ 213$ million to $\$ 385$ million representing an $80 \%$ increase (ChevronTexaco 2005; 2006).

In the business media, the Wall Street Journal has reported many instances of increased capital expenditures as a result of environmental initiatives. In its 40th 
Anniversary of Earth Day Special Report issue, the Journal documents organizational environmental initiatives and related corporate investments in environmental capital projects to date as far back as 1973 (Plank 2010). The Journal has since continued to highlight organizational capital expenditures for environmental initiatives, most recently, reporting on governmental outlays of over $\$ 25$ billion to help auto-makers significantly retool plants for electric car manufacturing (Mitchell 2010).

Even though there is no prior literature or theory underpinning the association between environmental initiatives and capital expenditures, the SEC's (2010) interpretive guidance and a plethora of anecdotal evidence suggest a positive association between firm-level environmental initiatives and capital expenditures. Accordingly, I advance the following hypothesis:

H1: There is a positive association between environmental initiatives and capital expenditures.

\section{Types of Environmental Initiatives and Capital Expenditures}

While I hypothesize that environmental initiatives at an aggregate level are associated with capital expenditures, I also seek to examine how the types of environmental initiatives influence a firm's capital expenditures. This is an important issue because environmental initiatives can vary in complexity and financial statement implications. I purport that a firm's investment in capital resources could differ based on the nature of the environmental initiative implemented due to the varying resource requirements of each type of initiative. 
I expect initiatives related to firm use and/or development of environmentally friendly products and services (PROD_SERV) to significantly affect capital expenditures. Such initiatives may involve the development of innovative remediation products and/or energy efficient processes, which in turn would require significant capital resources to implement. In order to meet expected environmental standards, some products may require design re-engineering, use of environmentally-friendly raw materials, and probably retooled or new, more sophisticated manufacturing equipment.

The impact of initiatives involving the use of substantial recycled materials (RECYCLE) may be conditional on the industry in which the firm operates. For example, firms operating in consumer non-durable industries in which packaging frequently consists of paper and plastic products may implement recycling initiatives in their packaging operations through the use of recycled paper and plastic. However, such initiatives would not materially affect its capital expenditures as these firms are essentially shifting their focus to recycled packaging material that would be inventoried. In contrast, manufacturers of recycled paper and plastic packaging materials may incur relatively greater capital expenditures as they retool their plants and equipment.

Additionally, I anticipate the two initiatives that most directly relate to reducing a firm's carbon footprint will require relatively substantial capital investments in order to achieve the high-level impact for which such initiatives are established. Initiatives related to notably strong pollution prevention programs (POLL_PREV) and those demonstrating a superior commitment to reducing firm impact on climate change (CLIMATE) may require substantial firm capital expenditures to implement. Firms 
participating in such initiatives demonstrate substantial reductions in emissions and toxic waste and also utilize energy efficiency, renewable energy, and clean fuel. In order to achieve such substantial climate-friendly goals, firms may have to retool, materially modify, or completely replace fixed assets currently used in operations. These types of major asset overhauls require significant firm capital expenditures. Furthermore, these initiative types may pertain directly to meeting stringent Environmental Protection Agency (EPA) specifications and guidelines, a motivation for substantial firm capital investment to ensure proper initiative execution and acceptably low levels of environmental impact.

Initiatives involving firm superior commitment to management systems, voluntary programs, and other environmentally proactive activities (OTHER) may have a relatively lower impact on capital expenditures than other initiatives. This is because such initiatives may serve more of a support function as opposed to requiring significant tangible capital resources. Alternatively, these activities could have a significant impact on capital expenditures if companies undergo substantial efforts and capital expenditures to enhance their operating and management systems for the long-term. Under this "other" category, companies may implement environmental initiatives such as sustainability programs, controls, and policies that place greater demand on both human and tangible capital. The theoretical differences between environmental initiative types and their effects on capital expenditures suggest the following hypothesis:

H2: The association between environmental initiatives and capital expenditures differs across the types of initiatives. 
While I set forth my varying expectations of the impact of the five types of environmental initiatives on capital expenditures, there is an inherent limitation in capturing this variation due to the nature of the KLD Research \& Analytics, Inc. (KLD) data that I utilize. Since KLD records a firm's environmental initiatives in binary form (1 if a firm participates in an initiative, and 0 otherwise), the extent of a firm's implementation of such initiatives is not captured in my data. While I theoretically and empirically examine the implications of each initiative type on capital expenditures, I acknowledge the possibility that the degree of initiative involvement not captured by KLD could impact the results.

\section{Sample and Research Design}

\section{Sample}

I use the KLD database to identify firms that engage in environmental initiatives. KLD independently rates companies trading on U.S. stock exchanges on a range of social performance dimensions including the environment (KLD 2006). ${ }^{19}$ The KLD database is widely used and considered highly reliable due to the independence of KLD analysts, the objective screening criteria used to rate firms, the consistency with which ratings are applied across companies, and the wide range of sources used to obtain the data (Waddock and Graves 1997; Hillman and Keim 2001). ${ }^{20}$ This database contains firm data as far back as 1991 and has been increasingly used in the past several years in

\footnotetext{
${ }^{19}$ Other dimensions of social performance data in KLD include community, diversity, employee relations, and human rights (KLD 2006)

${ }^{20}$ Discussions with KLD indicated that most of the environmental data are sourced from a firm's proxy statements such as the Form 10-K.
} 
management and accounting research (e.g., Cho et al., 2006; Bartkus and Glassman, 2008; Sharfman and Fernando, 2008; Chen et al., 2008, Cho et al. 2009).

I use three years of data from 2004 through 2006 since KLD restructured some of its data in prior years thus affecting comparability. My initial sample comprises 9,012 firm-year observations. I then obtain financial and corporate governance data for these observations from COMPUSTAT and the Corporate Library databases, respectively. After converging these databases with KLD, my sample reduces to 3,387 observations. I exclude financial firms based on two-digit standard industry classification (SIC $=60$ to 69) and further exclude observations without a December 31 year-end because KLD gathers and codes environmental data on a calendar-year basis. This final criterion is critical because failure to match the data years correctly can lead to inaccuracies in the analyses. This process yields 2,164 firm observations with all the necessary data. For my regression analyses to follow, I winzorised the data at the 1 percent and 99 percent levels, and the standard errors are adjusted for heteroskedasticity (White 1980). ${ }^{21}$

\section{Empirical Models and Variables}

I construct the following capital expenditure model based on the prior literature as described below.

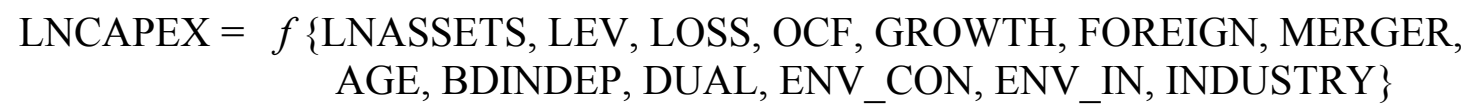

\footnotetext{
${ }^{21}$ My results are consistent if I use non-winzorised data and estimate standard and robust OLS regressions.
} 


\section{Dependent Variable: Natural Logarithm of Capital Expenditures}

I use the natural logarithm of capital expenditures as my dependent variable (LNCAPEX). In additional analyses, I also estimate my model by standardizing capital expenditures by total assets. Additionally, I estimate an abnormal capital expenditure model to determine whether clients with environmental initiatives have abnormally higher capital expenditures.

Test Variable: Environmental Initiative

The KLD database provides information on a firm's participation in environmental initiatives. For each of the five such initiatives identified by KLD, a firm is designated a binary variable ( 1 if an initiative is reported, 0 otherwise) to indicate a firm's participation in that specific environmental initiative. In order to test my first hypothesis (H1), I analyze the effect of overall environmental initiative, which I define as the natural logarithm of the total number of a firm's environmental initiatives (ENV_IN). This measure has been widely used in prior research and represents the extent of environmental initiatives undertaken by a firm (e.g., Waddock and Graves 1997; Hillman and Keim 2001). ${ }^{22}$

To address my second hypothesis, I disaggregate my ENV_IN variable into the five types of environmental initiatives in order to examine the effect of each initiative type on capital expenditures. The respective initiative is set to 1 if KLD reports a company has such an initiative, and 0 otherwise. The first initiative relates to a

22 Prior research equally ranks each component of the KLD environmental ratings because there is no theoretical basis for a ranking (Hillman and Keim 2001). Accordingly, I do not attempt to rank the environmental initiatives. 
company's use and/or development of environmentally beneficial products or services, such as innovative remediation products and energy efficient processes (PROD_SERV). The second applies to a company having notably strong pollution prevention programs, such as emissions and toxic-use reductions (POLL_PREV). The third refers to a firm which is a substantial user of recycled materials, or is a major factor of the recycling industry itself (RECYCLE). The fourth initiative indicates that a company has demonstrated a commitment to climate-friendly practices in order to reduce its impact on climate change and pollution; such measures include energy efficiency and the use of renewable energy and clean fuels (CLIMATE). Finally, the fifth environmental initiative in my data indicates a company's superior commitment to management systems, voluntary programs, and other environmentally proactive activities (OTHER). In the Appendix, I include examples of each type of initiative reported in proxy statements. I note here that beginning in the year 2006, KLD rated one additional environmental variable, ISO 14000 certification. However, since my data covers the period of 2004 through 2006, I exclude this variable from my primary analyses but perform additional tests after including this additional variable.

\section{Control Variables}

Given the exploratory nature of my study, I derive my control variables from relevant literature that examines and models some aspect of capital expenditure. I discuss the nature of each of these studies and describe the related control variables incorporated in my model. The studies I review can be classified as those that examine investment allocation and investment cash flow sensitivity. None of the studies reviewed focus on 
determinants of capital expenditures directly, as I do not believe such studies currently exist in the literature. However, given the nature of the studies reviewed as examining determinants of capital investment decisions and performance, I am able to construct a capital expenditure determinant model.

Whited's (1992) study of firm capital investment allocation shows that the financial health of a firm affects its ability to obtain external financing, which consequently affects the allocation of capital expenditures over time. In a subsequent finance study, Lang et al. (1996) bring clarity by showing a negative association between leverage and capital expansion. Similarly, Cleary (1999) reports that a firm's liquidity and ability to generate internal funds are related to investment decisions. Almeida et al. (2004) examine manufacturing firms over a 30 year period and find that investment cash flow sensitivity is affected by a firm's access to capital markets. Several studies also find that investment cash flow sensitivity is affected by factors such as financial performance, free assets, growth opportunities, and firm life cycle (e.g., Broussard 2004; Bhagat et al. 2005; Almeida and Campello 2007; Hovakimian 2009). Taken together, these studies imply that cash flows and leverage are potential determinants of capital expenditures.

In the initial accounting studies examining investment cash flow sensitivity, Biddle and Hilary (2006) and Biddle et al. (2009) show that firm size, profitability, growth opportunities, cash flow from operations, and leverage are significant determinants. These authors echo the implication from the finance literature that financial constrains limit a firm's capacity to invest in capital items. 
Drawing on the preceding studies, I include firm size, leverage, loss, cash flow, and growth opportunities as control variables. Firm size (LNASSETS) is measured as the natural logarithm of total assets less capital expenditures. I exclude capital expenditures from my measure of firm size because it is my dependent variable. I include leverage $(\mathrm{LEV}=$ ratio of total debt to total assets) because debt affects a firm's investment opportunities and constraints capital investments (Whited 1992; Lang et al. 1996; Cleary 1999; Bhagat et al. 2005; Biddle et al. 2009; Hovakimian 2009).

I also include a variable signifying an operating loss (LOSS $=1$ for firms reporting an operating loss in the current year, and 0 otherwise) as prior studies report an association between operating losses and capital expenditure policy (Bhagat et al. 2005; Biddle et al. 2009). To capture availability of internal funds, I include operating cash flow $(\mathrm{OCF}=$ net operating cash flow scaled by total assets) because most, if not all, studies I reviewed report a significant cash flow effect on capital investment policies (Whited 1992; Lang et al. 1996; Cleary 1999; Broussard 2004; Almeida et al. 2004; Bhagat et al. 2005; Biddle and Hilary 2006; Almeida and Campello 2007; Biddle et al. 2009; Hovakimian 2009).

As the extant literature suggests, capital expenditures are affected by the stage in a firm's life-cycle (Almeida and Campello 2007; Biddle et al. 2009; Hovakimian 2009) and firm growth (Cleary 1999; Bhagat et al. 2005; Biddle and Hilary 2006; Almeida and Campello 2007; Biddle et al. 2009; Hovakimian 2009), I include company age (AGE = natural logarithm of company age in years) and growth in sales (GROWTH $=$ percentage change in annual sales). Furthermore, I include a merger or acquisition in the current 
year $($ MERGER $=1$ if firm has experienced a merger or acquisition in current year, and 0 otherwise) because such structural changes have been shown to influence capital expenditures (Almeida et al. 2004; Bhagat et al. 2005).

I introduce the following variables not examined in the related literature as additional controls. A firm with foreign operations is usually regarded as more complex from a financial reporting perspective because of foreign transactions, transfer pricing, and tax issues. Foreign firms may also demand greater capital investment due to expansion and growth in non-U.S. markets. I, therefore, include foreign operations (FOREIGN) as a control, which equals 1 if a firm has foreign operations, and 0 otherwise. I include characteristics of the board (BDINDEP = proportion of independent members on the board) and a powerful CEO (DUAL $=1$ if the CEO also serves as the chairman of the board, and 0 otherwise) in order to explore the implications of these corporate governance measures on capital expenditures. I focus on the board and a powerful CEO because capital investment decisions are considered at the board of director level, and a powerful CEO may attempt to push his/her own agenda (over or under investment in capital expenditures).

In order to reliably evaluate the impact of my environmental initiatives test variable, I must control for the effect of environmental concerns on capital expenditures. Environmental concerns are actions taken against the firm by regulators such as the EPA who may demand and even litigate against the firm to rectify environmental violations. Firms may require greater capital expenditures in order to address such concerns. I observe this anecdotally in the proxy statements of several firms. For instance, British 
Petroleum, specifically discloses significant capital expenditures related to "the prevention, control, abatement or elimination of air, water and solid waste pollution" as a result of the nature of its operations (British Petroleum 2006). Pfizer makes specific references to large capital expenditures made "for environmental compliance purposes and for the clean-up of certain past industrial activity" (Pfizer 2006). Lastly, in yet another environmental concern-ridden industry, FirstEnergy, one of the largest utility companies in the U.S., describes in its annual report that "various federal, state and local authorities regulate FirstEnergy with regard to air and water quality and other environmental matters" and goes on to detail the significant capital expenditure requirements as a result of such concerns and regulations (FirstEnergy 2006).

I identify environmental concerns from the KLD database. KLD also reports dichotomous data on environmental concerns, and I create an environmental concern variable by aggregating six types of environmental concerns and taking its natural logarithm $($ ENV_CON $=$ natural logarithm of environmental concerns $){ }^{23}$ My results are consistent if I exclude observations with environmental concerns.

Finally, consistent with prior research (e.g., Lang et al. 1996; Biddle et al. 2009) I control for a firm's industry because capital expenditures could vary with the type of industry and to control for industry effects on environmental initiatives. I employ industry dummies according to the Fama and French ten industry portfolio (2010). For

\footnotetext{
${ }^{23}$ The six environmental concerns are firms: having large hazard waste liabilities or violations of waste management regulations, having violations of air, water, or other environmental regulations, being identified as one of the top manufacturers of ozone-depleting chemicals, having high legal levels of toxic chemical emissions into the air and water, being identified as a substantial producer of agricultural chemicals, having substantial direct or indirect revenues from the sale or combustion of coal or oil and its derivative fuel products, and having involvement in any other environmental controversy (KLD 2006)
} 
efficient reference, the operational definition of the variables, their expected association with capital expenditures, and data sources are summarized in Table 8 .

\section{Results}

\section{Descriptive Statistics}

Table 9 presents the descriptive statistics for my dependent and control variables for the full sample and by sub-samples of firms that have at least one environmental initiative (ENV_IN $>0)$ and those that do not partake in any environmental initiatives $\left(E N V \_I N=0\right) . \quad$ Regarding my dependent variable of interest, I find that capital expenditures (LNCAPEX) are significantly higher $(\mathrm{p}<0.01)$ for firms with environmental initiatives relative to those without environmental initiatives, which provides univariate support for $\mathrm{H} 1$. With regard to my control variables, firms with environmental initiatives have significantly $(\mathrm{p}<0.01)$ greater operating cash flow $(\mathrm{OCF})$, are older (AGE), are more likely to have foreign operations (FOREIGN) and environmental concerns (ENV_CON), and have a board comprised of more independent directors. However, firms with environmental initiatives experience lower growth than those without $(\mathrm{p}<0.01)$.

\section{Multivariate Analyses}

Table 10 reports Pearson and Spearman correlation matrices for the independent variables in my model. None of the correlations exceed 0.80 , the point beyond which potential multicollinearity problems could arise. All of the reported and untabulated variance-inflation factors (VIF) are below 2 and well below the threshold of 10 beyond which mulitcollinearity may be a problem (Kennedy 1992). 
Table 11 presents the results for the regression of capital expenditures on the controls and my test variable, environmental initiative (ENV_IN). The model has an adjusted R-squared of 0.46 suggesting a reasonable fit. The results for the control variables indicate that LNASSETS, LEV, OCF, FOREIGN, AGE, BDINDEP, DUAL, and ENV_CON are positive and significantly associated with LNCAPEX. LOSS is negatively associated with LNCAPEX. Most importantly, the results indicate a highly significant positive association between my test variable, ENV_IN and LNCAPEX. Hypothesis 1 is therefore supported. This finding suggests that firms with environmental initiatives support such initiatives through greater investment in capital resources.

In addition to measuring my environmental initiative test variable as the natural logarithm of total firm initiatives (ENV_IN) in my primary model, I perform additional analysis using a binary measure of firm environmental initiatives to examine the impact of any firm environmental initiative on capital expenditures. I label this new measure of my variable of interest ENV_YN and define it as 1 if a firm has at least one environmental initiative, and 0 otherwise. Table 12 reports the results of this additional analysis. The adjusted R-squared of 0.46 is the same as my initial model in Table 11 . All associations reported in my primary analysis hold with this new measure of my test variable. The finding here supports my earlier results and confirms that firms with at least one environmental initiative appear to support such initiatives through capital expenditures.

Next, I test my second hypothesis that examines the association between each type of environmental initiative and capital expenditures. In Table 13, I report the results 
of my regression of capital expenditures on environmental type indicator variables. This model is statistically significant, and the results for the control variables are consistent with my primary analysis in Table 11 and those in Table 12 , suggesting the model is structurally stable.

All environmental initiatives are positively related to capital expenditures, with CLIMATE, RECYCLE, and OTHER reporting statistical significance of this association $(\mathrm{p}<0.01)$. These findings suggests that while all environmental initiatives appear to be positively associated with capital expenditures, initiatives related to climate (CLIMATE), recycling (RECYCLE), and management systems, voluntary programs, and other environmentally proactive activities (OTHER) most significantly influence such expenditures. The consistency of a positive association with capital expenditures supports the proposition that regardless of the nature of the initiative, environmental initiatives demand greater firm support in the form of increased capital expenditures. This result is consistent with my primary analysis presented in Table 11 and also consistent with my secondary analysis presented in Table 12 .

To shed further light on the economic significance of these findings, I perform an analysis of the marginal effects of each initiative based on the results in Table 13 . Consistent with the above-reported initiative type results, I find that relative to firms without environmental initiatives, capital expenditures increase the most when the initiative is climate-related (CLIMATE), followed by recycling-related (RECYCLE), and finally, related to other proactive environmental systems, programs, and activities (OTHER). Quantifying these amounts, my results suggest that firms with these initiative 
types incur greater capital expenditures by an average of $124 \%, 87 \%$, and $74 \%$, respectively, compared to firms without such initiatives. However, if a firm has at least one initiative regardless of what type it is, then the impact on capital expenditures is not cumulative. Our dummy variable results (ENV_YN) suggest that capital expenditures are higher on average by about $101 \%$ for firms with an initiative compared to firms without any initiative. Furthermore, the analysis of our continuous measure of environmental initiatives (ENV_IN) suggests that when there is a one unit change (one standard deviation) in ENV_IN, on average, capital expenditures increase by about $81 \%$. These results provide strong support for the conclusion that environmental initiatives have significant economic consequences for capital expenditures.

\section{Additional Tests}

\section{Firm Size}

I test the sensitivity of my primary results to firm size as larger firms are more visible and have potentially more resources to engage in environmental initiatives. I partition my sample into small and large firms based on the median of LNASSETS (large firms $>$ median). For both the small and large firm subsamples, ENV_IN remains significant thus supporting my first hypothesis. When I perform this size sensitivity analysis by initiative type, my results for the both the large and small firm subsample are consistent with those in Table 13.

\section{Environmentally Sensitive Industries}

In order to examine the sensitivity of my results to environmentally sensitive industries, I partition my sample into firms operating in and not operating in such 
industries as defined by Cho et al. (2006). These industries include oil exploration, paper, chemical and allied products, pharmaceuticals, petroleum refining, and metals industries. For both subsamples of firms, my environmental initiative variable (ENV_IN) remains significant at the one percent level for both environmentally sensitive and nonenvironmentally sensitive industries. When I perform this analysis on each type of environmental initiative, I find that each initiative type remains significant with one

exception. Initiatives related to recycling (RECYCLE) for firms in environmentally sensitive industries become marginally insignificant, which could be attributed to low power as the number of such initiatives is small $(n=13)$.

\section{Yearly Analyses}

I test the sensitivity of my primary results to the financial year examined. As previously noted, my sample covers years 2004 to 2006 . I conduct my regression analysis for each year individually and find results consistent with my earlier results. In my primary tests, I excluded an additional environmental initiative variable, ISO 14000 certification, that KLD began rating in 2006. When I re-estimate my equations for the entire sample and separately for 2006 after including this additional environmental variable in my primary measure, ENV_IN or ENV_YN, I find consistent results. However, when I include this ISO 14000 initiative variable as per the analysis in Table 13, I find it is not significantly related to capital expenditures. This result is not surprising as ISO 14000 relates to meeting standards relating to documentation of management and control systems related to environmental issues and is not likely to place significant demands on capital expenditures. 


\section{Additional Measures of the Dependent Variable}

As an alternate measure of examining my capital expenditure dependent variable, I perform my analysis by scaling capital expenditures by total assets. I obtain results consistent with my primary analysis.

\section{Abnormally High Capital Expenditures}

To assess if firms with environmental initiatives have abnormally higher levels of capital expenditures, I first exclude the environmental initiative variable from my primary model and estimate the capital expenditure model to obtain the residuals. I then regress these residuals on the environmental initiative variable. In untabulated results, I observe ENV_IN is positive and significantly associated with the capital expenditure residuals ( $p$ $=0.000)$. When I repeat the analysis for environmental initiative types, I find results consistent with those in Table 13. These results are consistent with and complement my primary findings and suggest that firms with environmental initiatives have abnormally higher capital expenditures than firms without environmental initiatives.

\section{Potentially Omitted Variables}

Although I am confident in my establishment of a parsimonious model, I include potentially omitted variables that could have an effect on the significance of my variable of interest in explaining capital expenditures. I include the following additional control variables because the prior literature suggests they could influence a firm's investment in capital expenditures: natural logarithm of dividends (Almeida et al. 2004; Almeida and Campello 2007; Cleary 1999; Biddle et al. 2009; Hovakimian 2009), Zmijewski score to proxy for financial distress (Biddle et al. 2009), market to book ratio (Almeida and 
Campello 2007; Hovakimian 2009), financial reporting quality as proxied by firm restatements (Biddle and Hillary 2006; Biddle et al. 2009), and a corporate governance index to capture overall governance comprising board independence, duality, board meetings and presence of an accounting expert on the audit committee (Dhaliwal et al. 2010b). Including these potentially omitted variables does not impact the significance of my test variables, thus supporting the findings of my primary analysis and speaking to the robustness of the association between environmental initiatives and capital expenditures. Finally, when I exclude observations $(n=13)$ that restated their accounts due to capital expenditure accounting problems, I find my results remain the same.

\section{Conclusion}

Corporate social responsibility continues to gain importance and momentum in the eyes of the capital market, corporate regulators, and the public at large. Supporting this notion is the unprecedented market growth in socially responsible mutual funds and market indices over the past twenty years (Social Investment Forum 2010). Furthermore, corporate regulators such as the SEC continue to monitor corporate social responsibility through authoritative guidance such as the recent environmental disclosure interpretations set forth to increase corporate accountability on environmental issues (SEC 2010). The SEC's guidance specifically cites the significant effect environmental initiatives may have on the operational and financial risks of the firm, including specifically the demand for capital expenditures (SEC 2010). While there is some anecdotal evidence to support this assertion, extant research has yet to empirically examine the association between environmental initiatives and capital expenditures. I fill this gap in the literature and 
provide evidence that has implications for regulators, investors, auditors, management, and others interested in the financial implications of environmental initiatives.

Using a sample of 2,164 firm-year observations from 2004 to 2006 and after controlling for other potential determinants of capital expenditures, I find a significant positive association between environmental initiatives and capital expenditures. I find this association to persist regardless of the type of environmental initiative examined, although I observe a slightly higher association for those initiatives related to recycling, climate, or management systems, voluntary programs, and other environmentally proactive activities. These results are robust to a multitude of additional analyses.

This study is the first to empirically support the relationship between environmental initiatives and capital expenditures. The finding of a significant association suggests environmental initiatives have important financial and resource implications as asserted by the SEC. The results also support the notion that firms that secure funding for environmental initiatives are investing in capital resources to support such initiatives. Research examining investment cash flow sensitivity related to capital expenditure may wish to consider environmental initiatives as a potential variable.

Because capital expenditures are considered a high risk account from an audit perspective, my results also extend the findings of my first essay by providing further evidence that environmental initiatives could have implications for the auditor. The results suggest that an auditor's understanding and evaluation of a firm's environmental initiatives could help evaluate the risk of financial misreporting in the capital expenditure account. Currently, there is no other empirical evidence on the implications of 
environmental initiatives for the performance of the audit. I believe this would be an interesting consideration in future research given market, regulatory, investor, and public focus on socially responsible firms and the demand for related disclosures in proxy statements.

Some potential limitations of my study provide opportunities for future research. First, my environmental initiative data does not provide certain potentially important details of these initiatives, such as their pervasiveness to operations or their outcomes. The availability of such data would provide a greater ability to analyze the related implications on the financial statements. Second, I do not examine the incentives management faces to engage in environmental initiatives and the level of investment in capital resources. Currently, the environmental literature has not considered how managerial incentives are related to environmental initiatives, which provides a potentially interesting area for future research. Third, as with all empirical studies, I can only provide evidence of an association but cannot make inferences with respect to causation. Fourth, while my results are robust to a comprehensive set of control variables and additional tests, I cannot rule out the presence of other potential omitted correlated variables not studied in the capital expenditure literature to date. Lastly, while this second dissertation study extends the first study's auditor perspective by examining financial statement implications of environmental initiatives, such initiatives may be examined from other stakeholder perspectives as well, a potential future research area. 


\section{ENVIRONMENTAL INITIATIVES AND EARNINGS MANAGEMENT}

As I have demonstrated, corporate social and environmental responsibility are receiving increasing attention from regulators, market participants, the media, and the public at large (Social Investment Forum 2010). Initiatives related to the environment are receiving more intense scrutiny, a trend that is certainly expected to continue given recent corporate environmental disasters such as the British Petroleum oil spill. To enhance accountability and transparency, and assist capital market participants make more informed economic decisions, the Securities and Exchange Commission (SEC) recently released the aforementioned environmental disclosure transparency initiative (SEC 2010). ${ }^{24}$ Such disclosure initiatives underscore the unprecedented growth in socially and environmentally responsible investments over the past twenty years. ${ }^{25}$ Highlighting this growing emphasis on environmental accountability, some shareholders are even demanding executives and boards to terminate their relationships with companies presenting high environmental risk (Allen et al. 2010).

Nevertheless, some investors have suffered significant economic losses following scandals at environmentally responsible firms. Bohn (2010) documents anecdotes of

\footnotetext{
${ }^{24}$ This SEC interpretive release entitled Commission Guidance Regarding Disclosure Related to Climate Change more thoroughly outlines an organization's responsibility to disclose existing and potential climate change effects on annual report items such as the description of business, risk factors, environmental capital expenditures, and legal and regulatory disclosures. Compliance with this guideline is currently not mandatory although the SEC is considering introducing some mandatory disclosure requirements.

${ }^{25}$ Investments in these funds grew from $\$ 639$ billion to $\$ 2.71$ trillion between 1995 and 2007 (Social Investment Forum 2010). Organizations providing such mutual funds include Ariel Funds, Pax World Balanced Funds, New Alternatives Funds, and Green Century Funds; and indices include the KLD Index under the RiskMetrics Group and the Dow Jones Sustainability Index.
} 
fraudulent reporting and intentional abuse of millions of dollars invested in firms headed by high profile executives advertising socially responsible environmental initiatives. ${ }^{26}$ Such evidence counters the general notion that executives and the governance of environmentally responsible firms are of relatively higher standards (VanDyne et al. 1994; Fombrum et al. 2000).

A potential explanation for such unexpected economic consequences is that market participants believe environmentally responsible firms are an attractive investment based on the growth and performance of such firms (Social Investment Forum 2010). Capital market research affirms such beliefs by documenting a positive association between environmental initiatives and firm performance (e.g., Bragdon and Marlin 1972; Spicer 1978; Douglas and Judge 1995; Guenster et al. 2006; Semenova and Hassel 2008).

However, we know from the extant literature that firms use earnings management techniques to meet market expectations and portray financial strength that may not reflect economic reality (Burgstahler and Dichev 1997; Payne and Robb 2000; Dechow et al. 2000; Matsumoto 2002; Das and Zhang 2003; Abarbanell and Lehavy 2003; Lin et al. 2008). Given the increasing attention and investments poured into environmentally responsible firms, it is important to empirically ascertain the extent to which environmentally responsible firms engage in earnings management. The evidence

\footnotetext{
${ }^{26}$ Bohn specifically cites one recent high-profile case involving the Mantria Corporation in which the company claimed to be developing environmentally-friendly residential communities and fuel sources, but then faced a complaint filed by the SEC in November 2009 that alleged Mantria to be a Ponzi scheme that scammed approximately 300 investors out of $\$ 30$ million through fraudulent and unregistered securities offerings.
} 
from such analyses could imply whether the relatively better financial performance of firms engaged in environmental initiatives are achieved through management's manipulations of earnings or real economic performance. ${ }^{27}$ By doing so, this study contributes to the literature and practice by providing initial insight on the association between environmental initiatives and earnings management.

I hypothesize that firms engaged in environmental initiatives are associated with less earnings management based on both an external monitoring theory and an internal corporate culture theory. The former suggests that since environmentally responsible firms are more closely monitored and followed by regulators, investors, society, and the media, management of such firms will perceive greater scrutiny and compliance pressure. Together, these sentiments may motivate management of environmentally responsible firms to not pursue questionable financial reporting practices, as the consequences of doing so may harm their reputation and heighten the risk of litigation. Extant literature supports this notion of increased monitoring driving higher reported earnings quality or lower earnings management (Defond and Jiambalvo 1991; Dechow et al. 1996; Rajgopal and Venkatachalam 1997; Becker et al. 1998; Mitra 2002; Knayazvena 2007; Yu 2008).

The internal corporate culture theory suggests that firms with environmental initiatives foster a corporate culture exhibiting moral beliefs and values for the greater good, and happier, more productive, and more honest employees. Consequently, such corporate cultures encourage employees to act less out of self-interest, and in my context,

\footnotetext{
${ }^{27}$ I assume that if environmental initiatives are not significantly positively associated but are significantly negatively associated with earnings management then it is likely that such firms derive their relatively better financial performance through real economic gains rather than earnings management practices.
} 
potentially reduce the propensity for earnings manipulation. This line of reasoning is grounded in research presenting evidence of better corporate citizenship breeding stronger corporate culture (Etzioni 1988; Tichy et al. 1997; Sherman 1997; Turban and Greening 1997; Leonard 1997; Maignan et al. 1999; Maignan and Ferrell 2001), which fosters corporate commitment and reduces employee self-interest behavior (VanDyne et al. 1994; Fombrum et al. 2000). Based on these two theoretical frameworks, I predict an inverse association between firms engaged in environmental initiatives and earnings management.

Based on a sample of 2,095 firm-year observations from 2004 to 2006 and after controlling for other determinants of earnings management, I find support for the predicted negative association between environmental initiatives and earnings management proxied by total discretionary accruals estimated using the performanceadjusted modified-Jones model (Kothari et al. 2005). My results are consistent across total and income-increasing measures of discretionary accruals. I also find that discretionary accruals are most significantly negatively related to initiatives related to pollution prevention and climate protection. My results are robust to a number of additional tests including partitioning by firm size, environmentally sensitive industries, year, and financial performance, and the inclusion of potential omitted variables.

Overall, my initial results support the assertion that firms engaged in environmental initiatives exhibit lower earnings management. This finding supports the notion that the relatively superior financial performance exhibited by environmentallyresponsible firms is not likely a result of earnings manipulation but more likely due to 
real economic gains. Moreover, my results suggest that firms engaged in pollution prevention and/or climate protection initiatives are least likely to manage earnings. The evidence presented is consistent with the external monitoring and internal corporate culture theoretical frameworks drawn upon to predicate my hypothesis. My findings add insight to the literature and suggest areas of future research to advance our understanding of the implications of environmental initiatives. These findings also inform capital markets and regulators by documenting that environmentally-responsible firms are generally less likely to misreport financial information. Such findings could also assist auditors screening for firms that are more likely to misstate their earnings.

The remainder of this dissertation paper progresses as follows. In the next section, I review the relevant extant literature. I, then, discuss the sample and empirical models, presents my primary and additional analyses results, and finally, conclude the study.

\section{Background and Prior Literature}

I review two areas of pertinent literature underpinning my primary research question. I first review studies that examine the association between firm environmental and financial performance, as I have done in my first two dissertation papers. This review establishes the link between environmental initiatives and financial measures of firm success. The second literary area I review provides anecdotal and empirical support of the association between earnings management and firm financial performance. A review of this literature suggests that positive financial performance measures are sometimes achieved through devious earnings management means. Deductively, these 
two literary paradigms lead to my research question that examines the extent to which firms with environmental initiatives manage earnings.

\section{Environmental Performance and Financial Performance}

Although research in the U.S. has not historically examined corporate environmental performance as rigorously as in other developed nations, the existing studies do support an association between environmental and financial performance. ${ }^{28}$ As early as 1972, a positive association between environmental performance and financial performance was supported for U.S. firms in the pulp and paper industry (Bragdon and Marlin). This study along with Spicer's subsequent 1978 empirical archival results support the notion that firms with better environmental pollution-control devices tend to be more profitable. This research lays the foundation for the positive association between environmental performance and financial performance of U.S. firms.

In the more recent empirical archival studies, firm environmental preparedness and performance are significant and positively associated with accounting-based operational and financial performance measures, such as return on assets and Tobin's $q$ (Guenster et al. 2006; Semenova and Hassel 2008). Additionally, Douglas and Judge (1995) utilize a survey questionnaire administered to U.S. managers, due to lack of publicly available environmental initiative data, and find that firms with greater natural environment resources commitments exhibit superior environmental and financial performance. Collectively, these studies support a positive link between environmental

\footnotetext{
${ }^{28}$ Refer to Balabanis et al. (1998), Cronin (2001), and Hill et al. (2007) for a review of selected studies in other countries.
} 
initiatives and financial performance, establishing the first premise underpinning my research hypothesis.

\section{Earnings Management and Financial Performance}

The prevalence of corporate financial scandals in the late 1990s and early 2000s highlighted the harsh reality that strong financial performance is not always a result of true economic performance; rather, they suggest that financial performance can be manipulated by management to appear better than the economic reality of the firm. High profile companies such as Enron, Tyco, WorldCom, and Xerox, who appeared to be performing so well financially and commanded financial respect, were uncovered to have engaged in earnings manipulation to produce their strong financial results. For Xerox, April 2002 revealed a massive multi-year manipulation that the SEC claims kept Xerox's stock price artificially high in the late 1990 s, evidence of the manner in which investors and the financial world at large were misled (Bandler and Hechinger 2002).

Empirical research has similarly supported the association between earnings management and the appearance of strong financial performance. Given the importance the market places on meeting analyst forecasts, I review literature that has examined earnings management as a tool for achieving forecast targets, thereby presenting positive financial performance to the market. Burgstahler and Dichev (1997) provide evidence of management's use of discretionary accruals to avoid losses or earnings declines. Payne and Robb (2000) report that firms with pre-managed earnings below analysts' forecasts have greater positive abnormal accruals. Dechow et al. (2000) provide evidence that firms just meeting analysts' forecasts have higher abnormal accruals than those that just 
miss the target. Matsumoto (2002) presents a positive association between incomeincreasing discretionary accruals and the likelihood of avoiding negative earnings surprise. Das and Zhang (2003) show that managers use discretionary accruals to round up earnings per share to meet analyst forecasts. Interestingly, Abarbanell and Lehavy (2003) find that abnormal accruals are the main source of asymmetry in the distribution of forecast errors, indicating the use of accruals to meet analyst expectations in current and future periods. And although recent research has brought to light other forms of financial statement manipulation, Lin et al. (2008) still find evidence of firms' use of abnormal accruals to achieve analyst expectations when examining several forms of such manipulation. These empirical archival studies consistently support the reasoning that positive financial performance may not always be derived from real economic substance but from earnings management, thus supporting the second premise underpinning my research hypothesis.

\section{Hypothesis Development}

\section{Environmental Initiatives and External Monitoring}

Corporate environmental responsibility has received considerably more attention in recent years. Increasing societal pressures, media attention, and capital market interest paid to environmental issues all contribute to an overall greater visibility of environmentally active firms by regulators and the market alike. For example, Congress and corporate regulators, such as the SEC have increased their focus on corporate environmental responsibility through increased regulatory scrutiny, evidenced by such guidelines as the recent environmental disclosure rules set forth to increase corporate 
America's accountability to stakeholders (SEC 2010). ${ }^{29}$ Such increased regulatory attention complements the rising interest in social and environmental responsibility on behalf of capital markets. The past twenty years has seen unprecedented growth in socially responsible mutual funds and market indices, with investments growing exponentially from $\$ 639$ billion to $\$ 3.07$ trillion between 1995 and 2010 (Social Investment Forum 2010). ${ }^{30}$ Shareholders are even going so far as to demand companies to terminate relationships with companies presenting high environmental risk (Allen et al. 2010). Considering this monumental increase in societal, regulatory, and market coverage of environmentally responsible firms, I anticipate these firms will strive to provide high quality financial reporting in order to meet the increasing demand for such quality that comes along with rising levels of public scrutiny.

Extant literature has supported this notion of better earnings quality with an increased level of market attention. In the most recent of these studies, Knyazeva (2007) reports a negative association between analyst coverage, a proxy for market scrutiny, and earnings management, arguing that greater market coverage of firms serves as a partial substitute to other governance mechanisms in constraining earnings manipulation. $\mathrm{Yu}$ (2008) also finds a significant negative association between analyst coverage and the

\footnotetext{
${ }^{29}$ This SEC interpretive release entitled Commission Guidance Regarding Disclosure Related to Climate Change more thoroughly outlines an organization's responsibility to disclose existing and potential climate change effects on annual report items such as the description of business, risk factors, environmental capital expenditures, and legal and regulatory disclosures. Compliance with this guideline is currently not mandatory although the SEC is considering introducing some mandatory disclosure requirements.

${ }^{30}$ Organizations providing such mutual funds include Ariel Funds, Pax World Balanced Funds, New Alternatives Funds, and Green Century Funds; and indices include the KLD Index under the RiskMetrics Group and the Dow Jones Sustainability Index.
} 
level of firm discretionary accruals, and the likelihood to just meeting or beating earnings benchmarks. This research paradigm supports my argument that greater market visibility of environmentally responsible firms would likely dampen the extent of earnings manipulation by such firms.

Another external source of monitoring comes from institutional owners. Because institutional owners have greater resources, ability, and incentives to monitor firms in which they invest, they may serve as a monitoring mechanism to deter earnings management (Mitra 2002). As discussed previously, environmentally active firms have seen a massive influx of attention from mutual funds, market indices, and the market alike, undoubtedly increasing these firms attractiveness to more sophisticated institutional investors. In fact, as of 2010 , the amount of money invested in professionally managed, socially screened equities passed the $\$ 3.07$ trillion mark, with one of out of every eight institutional investment dollars part of a socially responsible portfolio (Social Investment Forum 2010). Prior research on institutional ownership has reported similar results to those reported in the analyst coverage literature with regard to the affect of increased market attention on earnings management. DeFond and Jiambalvo (1991) and Becker et al. (1998) find less prior period income-decreasing adjustments with the presence of blockholder ownership. Dechow et al. (1996) report that firms with blockholders are less likely to commit financial statement fraud. Perhaps most relevantly, Rajgopal and Venkatachalam (1997) find institutional ownership to be negatively related to the absolute value of discretionary accruals, consistent with institutional owners' role as monitors of earnings quality. These studies complement the analyst coverage literature in 
establishing my theoretical conjecture that firms participating in environmental initiatives are less likely to manage earnings due to the heightened external market forces closely monitoring such firms.

\section{Environmental Initiatives and Internal Corporate Culture}

Firm level corporate citizenship initiatives have been shown not only to impact financial performance as previously noted, but to impact corporate culture as well (Tichy et al. 1997). Corporate social responsibility helps integrate a firm into local community social networks, strengthening bonds between the companies, its employees, and the community (Etzioni 1988). Walter Haas, Jr., Chairman of Levi-Strauss, a company highly involved in social and environmental initiatives, verbalized this notion during an interview with Fortune Magazine in saying, "I believe that if you can create an environment that your people identify with, that is responsive to their sense of values, justice, fairness, ethics, compassion, and appreciation, they will help you be successful" (Sherman 1997, 104).

Extant empirical research directly supports the influence of corporate social responsibility in creating and maintaining happy and productive employees. Turban and Greening (1997) document that firms involved in corporate social responsibility are attractive to potential employees, and Maignan and Ferrell (2001) and Maignan et al. (1999) report higher employee commitment in such firms. Additionally, a survey of executives conducted by the Conference Board shows that employee productivity, morale, team work, and skill development improve significantly when corporate social initiatives are implemented (Leonard 1997). More recently, Lindgreen et al. (2009) 
report survey results administered to 401 U.S. firms on corporate social responsibility which echo the results of prior research; they also find that corporate social initiatives have a positive impact on employee morale and such initiatives motivate employees and bond them to the company.

If employees experience greater job satisfaction and develop greater bonding with the firm and its mission, they are less likely to act out of self-interest and engage in dysfunctional or immoral behavior. Strong corporate cultures, such as those provided by socially and environmentally responsible firms, are less likely to experience self-interest employee behavior that conflicts with firm objectives due to the close alignment between the individual employee's self-interest and the collective good of the company and society (Fombrun et al. 2000). Corporate social initiatives themselves also foster altruism and dampen individualistic thinking, thereby lessening the risk of purely self-interested behavior (Van Dyne et al. 1994). Extending this line of reasoning to financial reporting practices suggests that firms engaging in environmental initiatives have a corporate culture that would likely not condone manipulation of earnings to artificially boost earnings.

The preceding discussion of the two theoretical frameworks, external monitoring and internal corporate culture, together suggest that earnings management would be lower for firms with environmental initiatives. I, therefore, propose the following directional hypothesis:

H1: There is an inverse association between environmental initiatives and earnings management. 


\section{Sample and Research Design}

\section{Sample}

I identify firms with environmental data using the KLD Research \& Analytics, Inc database. KLD independently rates companies trading on U.S. stock exchanges with regard to their social performance across a range of dimensions, including the environment (KLD 2006). ${ }^{31}$ The KLD database is widely used and considered highly reliable because the KLD analysts are independent of the companies being rated, the analysts use objective screening criteria to rate firms, the ratings are applied consistently across companies, and a wide range of sources is used to obtain the data (Waddock and Graves 1997; Hillman and Keim 2001). ${ }^{32}$ This database, containing firm data as far back as 1991, has been increasingly used in the past several years in management and accounting research (e.g., Cho et al. 2006; Bartkus and Glassman 2008; Sharfman and Fernando 2008; Chen et al. 2008, Cho et al. 2009).

I begin my data year in 2004 since KLD restructured some of its data in prior years thus affecting comparability. My initial sample comprises 9,012 firm observations in calendar years 2004-2006. I then obtain financial and corporate governance data for these observations from COMPUSTAT and the Corporate Library databases, respectively. After converging these databases with KLD, my sample reduces to 3,697 observations. I then exclude financial firms based on two-digit standard industry

\footnotetext{
31 Other dimensions of social performance data in KLD include community, diversity, employee relations, and human rights (KLD 2006).

32 Discussions with KLD indicated that most of the environmental data are sourced from a firm's proxy statements such as the $10-\mathrm{K}$.
} 
classification (SIC $=60$ to 69 ) and remove observations without a December 31 year-end as KLD gathers and codes environmental data on a calendar-year basis. My final sample comprises 2,095 firm observations with all the necessary data. For my regression analyses to follow, I winzorised the data at the 1 percent and 99 percent levels, and the standard errors are adjusted for heteroskedasticity (White 1980). ${ }^{33}$

\section{Empirical Model and Variables}

I construct the following earnings management model based on the prior literature and variables described below:

\section{DACC $=f\{$ LN_MVE, LEV, MKTBK, LOSS, OCF, LAG_TOTACC, BIG4, MERGER, LITIGATION, ACEXP, ENV, YEAR FIXED EFFECTS, INDUSTRY \}}

Dependent Variable: Discretionary Accruals (DACC)

I use total discretionary accruals for my measure of earnings management for the following reasons. First, it is widely used and has been validated as a reliable proxy for earnings management (Kothari et al. 2005). Second, it is a more appropriate measure for my study because many environmental initiatives require significant resources that results in material capital expenditures. Capital expenditures are usually reported as long term assets, particularly, property, plant and equipment (PPE), which is captured in the total discretionary accruals model. Working capital or current accruals models do not capture earnings management related to PPE. Consistent with prior research, I use the following

\footnotetext{
${ }^{33}$ My results are consistent if I use non-winzorised data and estimate standard and robust OLS regressions.
} 
performance-adjusted modified-Jones model as proposed by Kothari et al. (2005) to estimate total discretionary accruals:

TOTACC $=\alpha_{0} /$ LAG_ASSETS $+\alpha_{1}(\Delta$ SALES $-\Delta$ REC $)+\alpha_{2}$ PPE + LAG_ROA $+\varepsilon$, where:

$$
\begin{aligned}
\text { TOTACC } & =\text { Total accruals defined as net income less cash from operations } \\
& \text { scaled by lagged total assets; } \\
\text { LAG_ASSETS } & \text { Lagged total assets; } \\
\Delta \text { SALES } & =\text { Change in sales scaled by lagged total assets; } \\
\Delta \text { REC }= & \text { Change in accounts receivable, netted out prior to scaling above; } \\
\text { PPE }= & \text { Net property, plant and equipment scaled by lagged total assets; } \\
& \text { and } \\
\text { LAG_ROA }= & \text { Lagged return on assets. }
\end{aligned}
$$

Following prior research, the residuals from the model above serve as my proxy for earnings management. I use both the absolute value of discretionary accruals (AB_DACC) and income-increasing discretionary accruals (INC_DACC) in my tests. Because management may manipulate earnings by using income-increasing or incomedecreasing accruals, the magnitude of discretion exercised is of interest, which is captured by AB_DACC. As my interest is also to see if environmentally responsible firms report better financial performance through earnings management, the use of INC_DACC would test management's use of income-increasing discretionary accruals.

\section{Test Variable: Environmental Initiative}

My environmental test variable (ENV) is measured three ways with my primary measure being the extent of environmental initiatives for each firm as reported by KLD. For each of the five environmental initiatives rated by KLD, a firm is designated a binary variable ( 1 if an initiative is reported, 0 otherwise) to indicate if the firm is involved in that specific environmental initiative. I take the sum of these five different initiatives 
(ENV_IN) to represent the extent of environmental initiatives undertaken by a firm. This approach is widely used in prior research (e.g., Waddock and Graves 1997; Hillman and Keim 2001). ${ }^{34}$

My second measure is a binary one that captures whether a firm is reported to have at least one environmental initiative that is coded 1, and 0 otherwise (ENV_YN). The purpose of this measure is to test whether a single initiative matters or if multiple initiatives jointly affect earnings management. Since environmental initiatives can vary in complexity and the level of resources demanded, a single initiative alone may be sufficient to attract market attention and influence corporate culture. This reasoning leads to my third measure.

Finally, to examine the impact of specific environmental initiatives on earnings management, I include each of the five types of environmental initiatives in my model. KLD describes the nature of each environmental initiative (KLD 2006). The first initiative relates to a company's use and/or development of environmentally beneficial products or services, such as innovative remediation products and energy efficient processes (PROD_SERV). The second applies to a company having notably strong pollution prevention programs, such as emissions and toxic-use reductions (POLL_PREV). The third refers to a firm which is a substantial user of recycled materials, or is a major factor of the recycling industry itself (RECYCLE). The fourth initiative indicates that a company has demonstrated a commitment to climate-friendly

\footnotetext{
34 Prior research equally ranks each component of the KLD environmental ratings because there is no theoretical basis for a ranking (Hillman and Keim 2001). Accordingly, I do not attempt to rank the environmental initiatives.
} 
practices in order to reduce its impact on climate change and pollution; such measures include energy efficiency and the use of renewable energy and clean fuels (CLIMATE). Finally, the fifth environmental initiative in my data indicates a company's superior commitment to management systems, voluntary programs, and other environmentally proactive activities (OTHER). In order to facilitate a clear understanding of these initiatives, I provide an actual disclosure for each initiative type taken directly from corporate annual reports in the Appendix.

I also note that beginning the year 2006, KLD rated one additional environmental variable, ISO 14000 certification. However, since my data covers 2004-2006, I exclude this variable from my primary analysis but perform additional analyses after including this additional variable.

\section{Control Variables}

Based on the prior literature, I include variables determined to be significantly related to measures of earnings management. I control for firm size (LN_MVE $=$ natural $\log$ of the market value of firm equity) but do not predict a direction because prior research reports mixed results (Frankel et al. 2002; Ashbaugh et al. 2003; Cohen and Zarowin 2010). I include leverage ( $\mathrm{LEV}=$ total liabilities to total assets) as has been done in extant literature (Frankel et al. 2002; Ashbaugh et al. 2003; Bergstresser and Philippon 2006; Cohen and Zarowin 2010; Choi et al. 2010) but do not predict its relation with discretionary accruals as firms may have incentives to manage earnings with greater leverage in order to avoid debt covenant violations, or they may have the incentive to refrain from earnings management due to the more stringent monitoring that accompanies 
greater debt financing. I include a firm's market-to-book ratio (MKTBK = market value of firm equity divided by book value of firm equity) as this growth measure has been found to be positively associated with discretionary accruals (Frankel et al. 2002; Ashbaugh et al. 2003; Bergstresser and Philippon 2006; Cohen and Zarowin 2010; Choi et al. 2010). I also include a loss indicator variable (LOSS $=1$ if firm had an operating loss for the financial year, and 0 otherwise) and expect it to be positively related to earnings management because loss firms have incentives to report higher earnings (Frankel et al. 2002; Ashbaugh et al. 2003; Choi et al. 2010).

I include operating cash flow (OCF = operating cash flow scaled by beginning of year total assets) as firms with greater cash flows from operations have been found to be less likely to manage earnings (Frankel et al. 2002; Myers et al. 2003; Ashbaugh et al. 2003; Choi et al. 2010). I also include a measure of the prior year's total accruals $($ LAG_TOTACC $=$ last year's total accruals scaled by beginning of year total assets $)$ as extant literature has done so in earnings management modeling to control for the variations in reversals of accruals over time (Frankel et al. 2002; Ashbaugh et al. 2003; Choi et al. 2010). I predict a negative association with discretionary accruals based on the findings in the prior literature. Additionally, I include auditor type (BIG4 = 1 if firm is audited by one of the Big 4 audit firms, and 0 otherwise) because large audit firms provide greater audit quality and thus may lessen earnings management (Frankel et al. 2002; Myers et al. 2003; Ashbaugh et al. 2003; Choi et al. 2010).

Consistent with prior research, I include a merger or acquisition during the financial year (MERGER $=1$ if merger or acquisition occurred, and 0 otherwise) as a 
control but do not predict a direction because of the mixed results in the literature (Frankel et al. 2002; Ashbaugh et al. 2003). I also include a litigation risk variable (LITIGATION $=1$ if the firm is in a high litigation risk industry identified by Francis et al. (1994) as SIC's 2833-2836, 3570-3577, 3600-3674, 5200-5961, 7370-7374, and 0 otherwise), as such risk has been associated with higher discretionary accruals (Frankel et al. 2002; Ashbaugh et al. 2003). I expect LITIGATION to be positively associated with earnings management.

I include a governance variable (ACEXP $=1$ if the audit committee contains at least one accounting expert, and 0 otherwise) because stronger governance mechanisms over financial reporting may have a negative impact on a firm's propensity to manage earnings (Bergstresser and Philippon 2006; Naiker and Sharma 2009; Dhaliwal et al. 2010b). I restrict the governance measure to accounting experts on the audit committee because this is the primary governance mechanism found to most significantly influence earnings management in recent research (Naiker and Sharma 2009; Dhaliwal et al. 2010b). In supplementary tests, I consider additional governance variables.

Lastly, I include year and industry indicator variables to control for variances due to these factors, as other earnings management studies have done (Myers et al. 2003; Bergstresser and Philippon 2006). For industry classification, I use the Fama and French ten industry portfolio (2010). For efficient reference, the operational definition of the variables, their expected association with my measure of earnings management, and data sources are summarized in Table 14. 


\section{Results}

\section{Descriptive Statistics}

Table 15 presents the descriptive statistics on environmental initiatives for the full sample and by firms with high and low levels of earnings management based on the median of the absolute value of discretionary accruals. With regard to my test variable, firms with greater environmental initiatives (ENV_IN) have a lower tendency to manage earnings. The mean ENV_IN is significantly $(\mathrm{p}<0.10)$ higher in the low DACC subsample relative to the high DACC sub-sample. This finding provides preliminary support for my central hypothesis, which will be tested more robustly in the multivariate analyses. Regarding my control variables, firms with higher DACC tend to have less operating cash flow, as expected. The descriptive data also show high DACC firms to have greater litigation risk and also to be larger, as proxied by market value of equity. They are also less likely to be audited by one of the Big 4 audit firms, as anticipated. These differences suggest that characteristics of firms with higher levels of earnings management vary significantly from firms with lower levels, which is consistent with prior research.

\section{Multivariate Analyses}

Table 16 reports Pearson and Spearman correlation matrices for the independent variables. Multicollinearity does not appear to be a problem. The largest Pearson correlation is between LEV and MKTBK, $(\mathrm{r}=-0.639)$ (Spearman correlation of -0.506), which is below multi-collinearity threat thresholds (Kennedy 1992). The highest of all 
the reported and untabulated variance-inflation-factors (VIF) is 2.056, well below the threshold of 10 beyond which multi-collinearity may be a problem (Kennedy 1992).

Table 17 presents the results for the regression of the absolute value of performance-adjusted modified-Jones discretionary accruals on the controls and my primary test variable, ENV_IN. The results for the control variables indicate that OCF and LAG_TOTACC are negative and significantly associated with AB_DACC, as anticipated. LEV is also significantly negatively associated with AB_DACC, suggesting that more leveraged firms are less likely to manage earnings via discretionary accruals, supporting the notion that more stringent monitoring by creditors may help lessen management's propensity to manipulate earnings. I find LITIGATION and LOSS to be significantly positively related to AB_DACC, as anticipated, signaling that firms that face greater litigation risk or firms that have incurred an operating loss in the financial year are more likely to manage earnings through discretionary accruals.

Most importantly, the results indicate a significant negative association between my test variable, ENV_IN and AB_DACC. My hypothesis is therefore supported. This finding suggests that firms with greater environmental initiatives engage in less earnings management as evidenced by lower levels of the absolute value of discretionary accruals. This finding is consistent with the theoretical frameworks supporting my hypothesis in that, whether due to increased external monitoring by the market, and/or due to innate corporate culture qualities, firms with greater environmental initiatives exhibit lower levels of earnings manipulation. 
I also perform the above analysis with an alternate dependent variable measure in Table 18. I isolate only those discretionary accruals that are income-increasing in order to provide more insight. Since prior literature has established that firms with greater environmental performance also appear to have greater financial performance, I perform my regression analysis on only those discretionary accruals that increase reported income. As shown in Table 18, my results for income-increasing discretionary accruals as the dependent variable are consistent with my analysis in Table 17. My control variable results are also the same. My hypothesis is, therefore, further supported, suggesting that firms engaged in more environmental initiatives are less likely to manage earnings through income-increasing accruals.

I also perform the above analyses using two additional measures of my test variable. Tables 19 and 20 present my absolute value and income-increasing discretionary accrual analyses employing an environmental initiative variable that captures whether a firm is reported by KLD to have engaged in at least one environmental initiative (ENV_YN). I find that ENV_YN is significant and negatively associated with both AB_DACC (Table 19) and INC_DACC (Table 20), consistent with my findings in Tables 17 and 18. These findings suggest that a firm engaged in at least one environmental initiative, regardless of what it may be, is negatively associated with the extent to which earnings

In order to gain further insight on the specific types of initiatives as they relate to earnings management, in Tables 21 and 22, I examine how each type of environmental initiative is related to discretionary accruals. I find that two types of environmental 
initiatives are significantly negatively associated with earnings management, measured as absolute value of discretionary accruals: those related to a firm's implementation of notably strong pollution prevention programs, such as emissions and toxic-use reductions (POLL_PREV), and those that indicate a firm's commitment to climate-friendly practices aimed at reducing its impact on climate change and pollution, such as energy efficiency and the use of renewable energy and clean fuels (CLIMATE). For income-increasing discretionary accruals (Table 22), I find that only POLL_PREV is negative and significant. $^{35}$ These findings support the notion that firms engaged in pollution prevention and/or climate-related environmental initiatives are the least likely to manage earnings. They also further support my hypothesis, adding clarity to those specific initiatives that most impact a firm's level of earnings manipulation.

While I find that two environmental initiatives are negatively related to total discretionary accruals, it would be appropriate to assess their economic significance. The analyses suggests that firms with initiatives related to pollution prevention and climatefriendly practices exhibit, on average, relatively lower earnings management of $3.2 \%$ and $1.9 \%$ compared to firms without such initiatives. Similarly, I find that a one unit (one standard deviation) change in environmental participation (ENV_IN) and firms with at least one initiative (ENV_YN) results in a $1.2 \%$ and $1.5 \%$ reduction in earnings management, respectively. I do not know if these are economically important because I am unaware of research showing what percentages of earnings management are material.

\footnotetext{
${ }^{35}$ The lack of significance for climate-related initiatives may be attributed to the small sample size of firms with income-increasing accruals and such initiatives $(\mathrm{n}=35)$.
} 
Certainly, in light of firms managing earnings to just meet or beat forecasted earnings by one penny, these percentages would be economically important.

\section{Additional Tests}

\section{Firm Size}

I test the sensitivity of my primary results to client size as larger firms are more visible and have potentially more resources to engage in environmental initiatives. I partition my sample into small and large firms based on median market value of equity (large firms $>$ median). For the large firm subsample, I obtain results consistent with my primary analyses; I find a significant negative association between earnings management and environmental initiatives (ENV_IN), and those initiatives found to have the strongest negative association (POLL_PREV and CLIMATE). On the contrary, the small firm subsample loses significance for these variables of interest. Upon closer investigation, I find that large firms report over five times the amount of environmental initiatives that small firms report in my sample (223 versus 44). This finding supports the aforementioned notion of greater resource availability for large firms to participate in environmental initiatives, and the non-significant finding for small firms may be due to the small number of such initiatives in the small firm sample. The disparity in association between large and small firms may also be attributed to the greater visibility, and therefore greater market and regulatory scrutiny, faced by large firms.

\section{Environmentally Sensitive Industries}

In order to examine the sensitivity of my results to environmentally sensitive industries, I partition my sample into firms operating in and not operating in such 
industries, as defined by Cho et al. (2006). These industries are oil exploration, paper, chemical and allied products, pharmaceuticals, petroleum refining, and metals industries. As with the reasoning underlying my hypothesis, I anticipate environmentally sensitive firms to be less likely to manage earnings due to greater external monitoring from regulators and the market, and/or due to internal corporate culture being influenced by a greater sense of social responsibility. On the other hand, a firm operating in a nonenvironmentally sensitive industry may have a stronger corporate culture of responsibility and ethical behavior because management of such firms may adopt a more voluntary strategy of being responsible corporate citizens by engaging in environmental initiatives. Thus, I expect environmental initiatives to be negatively associated in both sets of firms. My untabulated results of re-estimating my primary regression model for both sets of firms show that environmental initiative involvement (ENV_IN) is negative and significantly $(\mathrm{p}<0.10)$ associated with discretionary accruals for both sets of firms. When I estimate my model that incorporates specific types of initiatives, I find that for firms in environmentally sensitive industries, climate-related initiatives (CLIMATE) appear to have the strongest negative association with a firm's level of earnings management $(\mathrm{p}<0.10)$; whereas for non-environmentally sensitive industry firms, pollution prevention initiatives have the greatest negative impact on earnings management $(p<0.01)$. Overall, these results further support my primary analysis, as both industry groups appear to be less likely to manage earnings when participating more heavily in environmental initiatives. 


\section{Yearly Analyses}

I test the sensitivity of my primary results to the financial year examined. As previously noted, my sample covers years 2004 to 2006 . I conduct my regression analysis for each year individually and find results consistent with my earlier results. In my primary tests, I excluded an additional environmental initiative variable, ISO 14000 certification because KLD began rating this measure in 2006. When I re-estimate my equations for the entire sample and for 2006 after including this additional environmental variable in my primary measure, ENV_IN or ENV_YN, I find consistent results. Furthermore, when I include this ISO 14000 initiative variable in my initiative type analyses, I find it is negatively related to discretionary accruals, but not significantly.

\section{Financial Performance}

In order to test the sensitivity of my earnings management findings to firms reporting relatively high or low financial performance measures, I partition my sample based on the medians of two highly-analyzed performance measures: return on assets and earnings per share. For high return on asset firms, I find results consistent with my primary analysis with regard to the negative association previously found between discretionary accruals and environmental initiatives, and types of initiatives; however, one more initiative type shows significance in this partition: initiatives related to a firm's use and/or development of environmentally beneficial products or services (PROD_SERV) appear to be significantly positively related to earnings management for high performing firms. This finding potentially questions the true strength of financial performance for firms participating in such initiatives, as it could be inflated due to 
manipulation of earnings by management. With regard to firms with relatively lower return on assets, my findings are consistent with my primary analyses, except that initiatives related to climate protection (CLIMATE) become an insignificant indicator of earnings management for these firms. My results are also consistent when partitioning based on earnings per share, with the exception that for high earnings per share firms, recycling initiatives (RECYCLE) additionally appear to be significantly negatively related to earnings management, and as with low return on asset firms, low earnings per share firms do not appear to have an association between earnings management and climate initiatives (CLIMATE). Overall, these performance sensitivity tests support my hypothesis that firms with greater environmental initiatives tend to be associated with a lower manipulation of earnings, although there appears to be variation in the types of initiatives that drive this association.

\section{Environmental Concerns}

In addition to environmental initiative data, KLD reports and describes environmental concern data (KLD 2006). ${ }^{36}$ In order to test the sensitivity of my environmental initiative findings to the inclusion of such concerns in the earnings management models, I include an environmental concern variable that captures the sum of KLD-reported environmental concerns for each firm, similar to the derivation of the environmental initiative variable (ENV_IN) in the primary analysis. The test variable

\footnotetext{
${ }^{36}$ The six environmental concerns are firms: having large hazard waste liabilities or violations of waste management regulations, having violations of air, water, or other environmental regulations, being identified as one of the top manufacturers of ozone-depleting chemicals, having high legal levels of toxic chemical emissions into the air and water, being identified as a substantial producer of agricultural chemicals, having substantial direct or indirect revenues from the sale or combustion of coal or oil and its derivative fuel products, and having involvement in any other environmental controversy (KLD 2006).
} 
findings for environmental initiatives and types remain significantly negative and consistent. Additionally, I find that environmental concerns are significant and negatively related to discretionary accruals as well $(\mathrm{p}<0.01)$. This finding is consistent with my theoretical argument that firms facing greater regulatory and market scrutiny are less likely to manipulate earnings, as firms with known environmental concerns would undoubtedly face greater monitoring from external sources.

\section{Governance Index}

I test the impact of corporate governance on my results because stronger governance has been found to influence a firm's ability to manage earnings (Dhaliwal et al. 2010b) and propensity to engage in environmental activities (Johnson and Greening 1999; David et al. 2007). To capture the overall effect of governance and to ensure my model is parsimonious, I derive a governance index based on the independence and meeting frequency of the board of directors, the size and expert considerations of the audit committee, and the dual nature of the CEO also serving as chairman of the board. I select these governance factors because they have been found the most significantly and commonly associated with earnings management (Beasley 1996; Dechow et al. 1996; Sharma 2004; Dhaliwal et al. 2010b). Accordingly, I calculate an indicator variable for each of these governance characteristics on a firm basis as follows: for board independence, 1 if firm board independence percentage exceeds sample board independence percentage median, and 0 otherwise; for board meetings, 1 if firm board meetings exceed sample board meetings median, and 0 otherwise; for audit committee size, 1 if firm audit committee size equals to or exceeds three, and 0 otherwise; for audit 
committee expert, 1 if firm has an accounting expert on the audit committee, and 0 otherwise; and lastly, for duality, 1 if a firm's CEO does not also serve as chairman of the board; and 0 otherwise. I then derive my governance index as the sum of each of these five indicator variables, whereby the higher the index, the stronger the governance mechanisms in place. After incorporating this measure into the model, my test variable

of interest (ENV_IN) remains negative and significantly related to earnings management $(p<0.01)$, supporting my primary analyses. Furthermore, my test by types of initiatives yields consistent results.

\section{Conclusion}

As previously highlighted, the corporate world has observed an unprecedented increase in the attention paid to environmental accountability from a range of stakeholders, including Congress, regulators, the market, and society at large. Recent authoritative guidelines in accounting, such as the SEC's release describing the need to increase environmental disclosure transparency (SEC 2010), underscore the importance of environmental considerations in accounting research. This study seeks to add insight to this developing paradigm by examining the association between environmental initiatives and earnings management.

I anticipate firms with environmental initiatives will exhibit lower levels of earnings management based on two theoretical frameworks. The first is an external monitoring theory that suggests the greater attention, monitoring, and scrutiny of environmentally-active firms from regulators, capital market participants, and society will lessen management's motives to artificially manipulate earnings. This theory is 
supported by extant research that documents higher financial reporting quality for firms subject to greater external monitoring (Defond and Jiambalvo 1991; Dechow et al. 1996; Rajgopal and Venkatachalam 1997; Becker et al. 1998; Mitra 2002; Knayazvena 2007; Yu 2008).

The second framework I rely on is an internal corporate culture theory. This theory posits firms with environmental initiatives have a stronger corporate culture because commitment to environmental responsibility stems from values and belief systems that are ethical and moral, and discourages pursuit of self-interest behavior. Such a culture is expected to be associated with lower earnings management and is supported by extant literature documenting similar effects in non-accounting contexts (Etzioni 1988; Tichy et al. 1997; Sherman 1997; Turban and Greening 1997; Leanoard 1997; Maignan et al. 1999; Maignan and Ferrell 2001; VanDyne et al. 1994; Fombrum et al. 2000). Together, these two theoretical frameworks support my directional hypothesis that predicts an inverse association between environmental initiatives and earnings management.

My results support this hypothesis. I consistently find a significant negative association between environmental initiatives and earnings management, measured using the performance-adjusted modified-Jones model (Kothari 2005). My results hold for both absolute value and income-increasing total discretionary accruals. I further find that this association is strongest for environmental initiatives related to pollution prevention and climate protection efforts. Future research with more specific data using both empirical archival and survey methods could provide greater interpretation of these 
initiative type results. Nevertheless, my results show that firms engaged in environmental initiatives appear to be less likely to manage earnings via discretionary accruals.

Given that firms with greater environmental initiatives tend to report stronger financial results (Bragdon and Marlin 1972; Spicer 1978; Douglas and Judge 1995; Guenster et al. 2006; Semenova and Hassel 2008), and also given that managers in general have been shown to manipulate earnings via discretionary accruals in order to appear stronger financially (Burgstahler and Dichev 1997; Payne and Robb 2000; Dechow et al. 2000; Matsumoto 2002; Das and Zhang 2003; Abarbanell and Lehavy 2003; Lin et al. 2008), my finding of lower earnings management for environmentallyresponsible firms supports the notion that the strong financial performance documented for such firms is not a result of earnings management, to the extent the evidence suggests in this study. My results imply the relatively better financial performance of environmentally responsible firms reported in the prior literature is likely due to real economic gains as such firms seem to have developed better relationships with stakeholders, consumers and society, which in turn, creates loyalty and generates revenues (e.g., Fry et al. 1982; Hillman and Keim 2001; Lev et al. 2010). Accordingly, I believe that environmentally responsible firms have fewer incentives to manipulate earnings to report better performance.

Some potential limitations of my study provide opportunities for future research. First, a closer examination of the factors driving the lower discretionary accruals for environmentally-responsible firms could be examined. More specifically, is this 
association attributable to one or both of my two proposed theories (external monitoring and internal corporate culture), or some other theory yet to be explored? Second, while I use discretionary accruals as a proxy for earnings management, it has limitations, and future studies could examine other proxies to test the sensitivity and generalizability of my results. Some of these proxies include the likelihood of financial restatement, fraud, the propensity to meet or beat analyst forecasts, and earnings conservatism. Third, my environmental initiative data does not provide information on the likely success of the initiative, nor does it capture the extent of the financial investment related to a particular initiative. Such information, however, would allow for more thorough examination as it relates to earnings management. For example, some initiatives may be more demanding of resources, more costly to implement, and their success may be questionable. These types of initiatives could incentivize management to justify the investment in these initiatives as they face pressure to meet market expectations. Fourth, I do not specifically examine the incentives facing management to engage in environmental initiatives and how these affect the association between initiatives and discretionary accruals. Fifth, as with any empirical examination, I can provide evidence of an association; however, inferences cannot be made with respect to causation. Sixth, while my results are robust to a comprehensive set of control variables and additional tests, I cannot rule out the presence of other potential omitted correlated variables not yet uncovered in extant earnings management literature. Lastly, while this third dissertation essay examines earnings quality and expands upon environmental initiative implications from the first two studies, these initiatives, again, may be examined from the perspectives of a variety 
of stakeholders, creating great promise for future important research to add insight to this area of growing public interest.

\section{DISCUSSION}

Today's corporate world is evermore influenced by environmental considerations, with the United States gaining particular momentum over the past twenty years relative to its historical consideration of environmental issues (Social Investment Forum 2010). Stakeholders from every direction appear to be placing more value on environmental accountability, a trend that is certainly expected to continue given recent highlypublicized corporate environmental disasters as the British Petroleum oil spill. Emerging regulations, such as those recently prescribed by the Securities and Exchange Commission, set forth guidelines for companies to enhance their environmental disclosure and transparency to stakeholders (SEC 2010).

Given this heightened interest in environmental accountability, an examination of the strategic environmental initiatives undertaken by firms can shed light on the implications of firm measures to achieve stronger environmental performance. Extant literature is limited with regard to examining such environmental initiatives as they relate to various accounting and auditing issues. In my dissertation, I begin to address these issues by examining firm environmental initiatives in association with audit fees, capital expenditures, and earnings management.

In my first dissertation essay, I examine the association between environmental initiatives and audit fees, a proxy for auditor effort. My findings suggest that auditors do 
consider client environmental initiatives when performing the annual financial statement audit, thus supporting auditors' recognition of the increased market reliance on corporate environmental information and the demand this places on the annual financial statement audit.

In my second dissertation essay, I follow up on my first paper's findings by examining how firm environmental initiatives affect the financial statements which are being audited. While their strong impact on capital expenditures has been anecdotally supported by such parties as the Securities and Exchange Commission (2010), extant research has yet to empirically examine the this association. I, therefore, examine the relationship between environmental initiatives and capital expenditures and find the first empirical evidence of increased levels of capital expenditures with increased environmental initiative participation, supporting anecdotal claims and providing deeper insight into the financial statement implications of environmental initiatives.

Lastly, my third dissertation essay expands upon my prior auditing and accounting findings to examine the quality of earnings reported by firms participating in environmental initiatives. I examine the association between environmental initiatives and earnings management, measured by discretionary accruals calculated under the performance-adjusted modified-Jones model (Kothari 2005). My results suggest that firms engaged in environmental initiatives are less likely to manage earnings, thus supporting the true economic merit of the superior financial performance exhibited by strong environmental performers. 
While I discuss the potential limitations of each dissertation study specifically therein, some common limitations of the dissertation provide opportunities for future research. First, my environmental initiative data does not provide information on the likely success of the initiative, nor does it capture the extent of the financial investment related to a particular initiative. Such information, however, would be helpful in more closely examining the implications of all three studies. Second, I do not examine the incentives management faces to engage in environmental initiatives and how these affect the associations examined. For example, I could gain more insight on the environmental initiative behavior of firms seeking to reduce the cost of capital, or obtain new financing, or those seeking some federal or state concessions. Third, as with all empirical studies, I can only provide evidence of an association but cannot make inferences with respect to causation. Fourth, while my results are robust to a comprehensive set of control variables and additional tests, I cannot rule out the presence of other potential omitted correlated variables from each of the studies. Lastly, environmental initiatives can be examined from the perspectives of a variety of stakeholders. This opens many avenues of future research dedicated to gaining a better understanding of corporate environmental initiative participation, a topic gaining tremendous momentum in practice. My dissertation provides a foundation for this research, and I hope that the studies and findings herein encourage debates and discussions on this important issue facing today's corporate world. 


\begin{tabular}{|c|c|c|}
\hline \multicolumn{3}{|c|}{$\begin{array}{c}\text { TABLE 1 } \\
\text { Essay One Variable Definitions }\end{array}$} \\
\hline Variable Name & $\begin{array}{l}\text { Expected } \\
\text { Sign }\end{array}$ & Variable Measurement \\
\hline \multicolumn{3}{|c|}{ Panel A: Dependent Variable } \\
\hline LNAUDFEE & & $\begin{array}{l}\text { Natural logarithm of audit fees paid to the external } \\
\text { auditor (Audit Analytics) }\end{array}$ \\
\hline \multicolumn{3}{|c|}{ Panel B: Test Variables } \\
\hline ENV_IN & $?$ & $\begin{array}{l}\text { Natural logarithm of the sum of types of environmental } \\
\text { initiatives for a firm in a given year as reported by KLD } \\
\text { Analytics. }\end{array}$ \\
\hline EI_YN*LNCAPEX & + & $\begin{array}{l}\text { Multiplicative product of EI_YN and LNCAPEX where } \\
\text { EI_YN equals } 1 \text { if KLD reports a firm has at least one } \\
\text { environmental initiative, and } 0 \text { otherwise, and LNCAPEX } \\
\text { is the natural logarithm of capital expenditure } \\
\text { (Compustat). }\end{array}$ \\
\hline \multicolumn{3}{|c|}{ Panel B: Control Variables } \\
\hline LNASSETS & + & Natural logarithm of total assets (Compustat). \\
\hline IND_ES & $?$ & $\begin{array}{l}1 \text { if firm is a member of an environmentally-sensitive } \\
\text { industry as defined by Cho et al. (2006), and } 0 \text { otherwise. }\end{array}$ \\
\hline SEGNUM & + & Number of reported business segments (Compustat). \\
\hline FOREIGN & + & $\begin{array}{l}1 \text { if firm has foreign operations, and } 0 \text { otherwise } \\
\text { (Compustat). }\end{array}$ \\
\hline INVAR & + & $\begin{array}{l}\text { Inventory plus accounts receivable scaled by total assets } \\
\text { (Compustat). }\end{array}$ \\
\hline LOSS & + & $\begin{array}{l}1 \text { if firms reports a loss in the fiscal year, and } 0 \text { otherwise } \\
\text { (Compustat). }\end{array}$ \\
\hline LEV & + & Total debt to total assets (Compustat). \\
\hline BDSIZE & $?$ & $\begin{array}{l}\text { Number of members on the Board of Directors } \\
\text { (Corporate Library). }\end{array}$ \\
\hline BDMTGS & $?$ & Number of annual board meetings (Corporate Library). \\
\hline BDINDEP & $?$ & $\begin{array}{l}\text { Proportion of board members who are independent } \\
\text { (Corporate Library). }\end{array}$ \\
\hline BIG4 & + & $\begin{array}{l}1 \text { if firm is audited by a Big } 4 \text {, and } 0 \text { otherwise } \\
\text { (Compustat). }\end{array}$ \\
\hline LNNAS & $?$ & Natural logarithm of non-audit fees (Audit Analytics). \\
\hline ZSCORE & + & $\begin{array}{l}\text { Zmijewski score as an indicator of financial distress } \\
\text { (Compustat). }\end{array}$ \\
\hline GROWTH & + & $\begin{array}{l}\text { Percentage growth in sales over the prior year } \\
\text { (Compustat). }\end{array}$ \\
\hline INITIAL & $?$ & $\begin{array}{l}1 \text { if the auditor is in the initial year of the audit, and } 0 \\
\text { otherwise (Audit Analytics). }\end{array}$ \\
\hline SPECIAL & + & Special items scaled by total assets (Compustat). \\
\hline
\end{tabular}




\section{Table 2}

Descriptive Statistics for Environmental Initiatives

\begin{tabular}{|c|c|c|c|c|c|c|}
\hline \multirow[b]{2}{*}{$\underline{\text { Variable }}$} & \multicolumn{2}{|c|}{ Incidence of Environmental Initiatives } & \multicolumn{2}{|c|}{$\begin{array}{c}\text { Environmentally Sensitive } \\
\text { Industries } \\
\underline{(n=479)}\end{array}$} & \multicolumn{2}{|c|}{$\begin{array}{c}\text { Non-Environmentally Sensitive } \\
\text { Industries } \\
\underline{(n=1,995)}\end{array}$} \\
\hline & $\underline{\text { Number }}$ & $\underline{\%}$ & $\underline{\text { Number }}$ & $\underline{\%}$ & $\underline{\text { Number }}$ & $\underline{\%}$ \\
\hline PROD_SERV & 67 & 2.71 & 21 & 4.38 & 46 & $2.31 * *$ \\
\hline POLL_PREV & 54 & 2.18 & 21 & 4.38 & 33 & $1.65^{* * *}$ \\
\hline RECYCLE & 39 & 1.58 & 13 & 2.71 & 26 & $1.30^{*}$ \\
\hline CLIMATE & 110 & 4.45 & 26 & 5.43 & 84 & 4.21 \\
\hline OTHER & 57 & 2.30 & 19 & 3.97 & 38 & $1.90 * *$ \\
\hline TOTAL & 327 & 13.2 & 100 & 20.8 & 227 & $11.38 * * *$ \\
\hline \multicolumn{7}{|c|}{$\begin{array}{l}\text { ***,**, }{ }^{*} \text { denote significant differences between environmentally sensitive industries and non-environmentally sensitive industries at the } 0.01,0.05 \text {, } \\
\text { and } 0.10 \text { levels, respectively. } \\
\text { PROD_SERV }=1 \text { if a firm uses and/or develops environmentally beneficial products or services, such as innovative remediation products and energy } \\
\text { efficient processes, and } 0 \text { otherwise; POLL_PREV }=1 \text { if a firm has notably strong pollution prevention programs, such as emissions and toxic-use } \\
\text { reductions, and } 0 \text { otherwise; RECYCLE }=1 \text { if a firm is a substantial user of recycled materials, or is a major factor of the recycling industry itself, } \\
\text { and } 0 \text { otherwise; CLIMATE }=1 \text { if a firm demonstrates a commitment to climate-friendly practices in order to reduce its impact on climate change } \\
\text { and pollution; such measures include energy efficiency and the use of renewable energy and clean fuels, and } 0 \text { otherwise; and OTHER = } 1 \text { if a firm } \\
\text { has superior commitment to management systems, voluntary programs, and other environmentally proactive activities. }\end{array}$} \\
\hline
\end{tabular}


Table 3

Descriptive Statistics for Essay One Full Sample and for Firms with and without Environmental Initiatives

\begin{tabular}{|c|c|c|c|c|c|c|c|c|c|c|}
\hline \multirow[b]{2}{*}{ Variable } & \multicolumn{3}{|c|}{$\begin{array}{c}\text { Full Sample } \\
\underline{(\mathrm{n}=2,474)}\end{array}$} & \multicolumn{3}{|c|}{$\begin{array}{c}\text { Firms with Environmental } \\
\text { Initiatives } \\
(\mathbf{n}=\mathbf{2 4 8})\end{array}$} & \multicolumn{3}{|c|}{$\begin{array}{c}\text { Firms without Environmental } \\
\text { Initiatives } \\
\underline{(\mathbf{n}=\mathbf{2 , 2 2 6})}\end{array}$} & \multirow{2}{*}{$\begin{array}{c}\frac{\text { Test of }}{\text { Differences }} \\
\underline{\text { t-statistic }}\end{array}$} \\
\hline & Mean & $\underline{\text { Median }}$ & $\underline{\text { SD }}$ & Mean & $\underline{\text { Median }}$ & $\underline{\text { SD }}$ & Mean & Median & $\underline{\text { SD }}$ & \\
\hline LNAUDFEE & 14.47 & 14.39 & 1.04 & 15.41 & 15.61 & 1.15 & 14.36 & 14.31 & 0.97 & $13.81 * * *$ \\
\hline LNASSETS & 12.11 & 11.96 & 1.52 & 13.52 & 13.80 & 1.55 & 11.95 & 11.83 & 1.43 & $15.24 * * *$ \\
\hline IND_ES & 0.19 & 0.00 & 0.40 & 0.28 & 0.00 & 0.45 & 0.18 & 0.00 & 0.39 & $3.31 * * *$ \\
\hline SEGNUM & 6.07 & 4.00 & 5.25 & 8.48 & 9.00 & 6.50 & 5.80 & 3.00 & 5.02 & $6.28 * * *$ \\
\hline FOREIGN & 0.30 & 0.00 & 0.46 & 0.45 & 0.00 & 0.50 & 0.28 & 0.00 & 0.45 & $4.96^{* * *}$ \\
\hline INVAR & 0.22 & 0.20 & 0.15 & 0.21 & 0.20 & 0.11 & 0.22 & 0.20 & 0.16 & 0.92 \\
\hline LOSS & 0.11 & 0.00 & 0.32 & 0.13 & 0.00 & 0.33 & 0.11 & 0.00 & 0.31 & 0.69 \\
\hline LEV & 0.56 & 0.55 & 0.26 & 0.50 & 0.52 & 0.24 & 0.57 & 0.56 & 0.27 & $3.84 * * *$ \\
\hline BDSIZE & 10.79 & 10.00 & 3.91 & 12.68 & 11.00 & 4.23 & 10.58 & 10.00 & 3.82 & $7.51 * * *$ \\
\hline BDMTGS & 7.72 & 7.00 & 3.50 & 8.24 & 8.00 & 2.71 & 7.66 & 7.00 & 3.57 & $3.11 * * *$ \\
\hline BDINDEP & 0.66 & 0.67 & 0.16 & 0.74 & 0.75 & 0.12 & 0.65 & 0.67 & 0.16 & $11.09 * * *$ \\
\hline BIG4 & 0.96 & 1.00 & 0.20 & 0.98 & 1.00 & 0.13 & 0.95 & 1.00 & 0.21 & $3.24 * * *$ \\
\hline LNNAS & 12.06 & 12.54 & 2.92 & 13.62 & 13.95 & 2.14 & 11.88 & 12.42 & 2.94 & $11.60 * * *$ \\
\hline ZSCORE & -1.50 & -1.57 & 1.61 & -1.13 & -1.06 & 1.34 & -1.54 & -1.62 & 1.63 & $4.49 * * *$ \\
\hline GROWTH & 1.68 & 0.11 & 0.25 & 0.11 & 0.09 & 0.17 & 1.85 & 0.12 & 0.25 & 0.35 \\
\hline INITIAL & 0.09 & 0.00 & 0.29 & 0.05 & 0.00 & 0.22 & 0.10 & 0.00 & 0.30 & $2.82 * * *$ \\
\hline SPECIAL & 0.02 & 0.00 & 0.05 & 0.01 & 0.00 & 0.03 & 0.02 & 0.00 & 0.06 & 0.75 \\
\hline LNCAPEX & 4.30 & 4.19 & 1.76 & 5.83 & 6.13 & 1.65 & 4.13 & 3.99 & 1.69 & $15.83 * * *$ \\
\hline
\end{tabular}

***,**,* denote significance at the $0.01,0.05$, and 0.10 levels, respectively. See Table 1 for variable definitions.

${ }^{\mathrm{b}}$ Test results are identical when I use non-parametric tests. 
Table 4

Correlations: Pearson (Spearman) Correlations are Presented in the Upper (Lower) Diagonal ${ }^{\mathbf{a}}$

\begin{tabular}{|c|c|c|c|c|c|c|c|c|c|}
\hline & LNASSETS & IND ES & $\underline{\text { SEGNUM }}$ & $\underline{\text { FOREIGN }}$ & INVAR & $\underline{\text { LOSS }}$ & $\underline{\text { LEV }}$ & BDSIZE & $\underline{\text { BDMTGS }}$ \\
\hline LNASSETS & & 0.063 & 0.265 & 0.076 & -0.192 & 0.016 & -0.128 & 0.419 & 0.173 \\
\hline IND_ES & 0.061 & & -0.017 & 0.112 & -0.096 & 0.056 & -0.078 & 0.010 & 0.033 \\
\hline SEGNUM & 0.227 & -0.030 & & -0.001 & 0.073 & 0.062 & -0.071 & 0.001 & 0.051 \\
\hline FOREIGN & 0.068 & 0.112 & -0.019 & & 0.134 & -0.023 & -0.020 & 0.034 & -0.047 \\
\hline INVAR & -0.186 & -0.066 & 0.121 & 0.183 & & -0.032 & 0.030 & -0.069 & -0.153 \\
\hline LOSS & 0.017 & 0.056 & 0.038 & -0.023 & -0.034 & & 0.082 & -0.005 & 0.007 \\
\hline LEV & -0.131 & -0.097 & -0.060 & -0.009 & 0.049 & 0.047 & & -0.027 & 0.009 \\
\hline BDSIZE & 0.416 & 0.023 & -0.017 & 0.034 & -0.065 & 0.004 & -0.016 & & 0.131 \\
\hline BDMTGS & 0.199 & 0.051 & 0.053 & -0.029 & -0.136 & -0.002 & -0.009 & 0.148 & \\
\hline BDINDEP & 0.188 & 0.052 & 0.166 & 0.048 & 0.058 & 0.030 & -0.043 & -0.031 & 0.081 \\
\hline BIG4 & 0.198 & -0.013 & 0.041 & 0.021 & -0.027 & 0.005 & 0.006 & 0.078 & 0.017 \\
\hline LNNAS & 0.572 & 0,017 & 0.193 & 0.200 & 0.044 & 0.008 & -0.065 & 0.224 & 0.184 \\
\hline ZSCORE & 0.373 & 0.055 & 0.113 & -0.097 & -0.128 & 0.030 & -0.099 & 0.227 & 0.168 \\
\hline GROWTH & -0.086 & 0.095 & -0.049 & -0.028 & 0.049 & -0.009 & 0.059 & -0.134 & -0.045 \\
\hline INITIAL & -0.133 & -0.014 & -0.025 & -0.007 & -0.004 & -0.024 & 0.018 & -0.085 & 0.006 \\
\hline SPECIAL & 0.093 & 0.089 & 0.042 & 0.115 & -0.002 & 0.025 & -0.018 & 0.041 & 0.147 \\
\hline LNCAPEX & 0.864 & 0.123 & 0.170 & 0.022 & -0.246 & 0.001 & -0.146 & 0.387 & 0.160 \\
\hline ENV IN & 0.289 & 0.076 & 0.124 & 0.110 & 0.020 & 0.016 & -0.076 & 0.170 & 0.094 \\
\hline
\end{tabular}




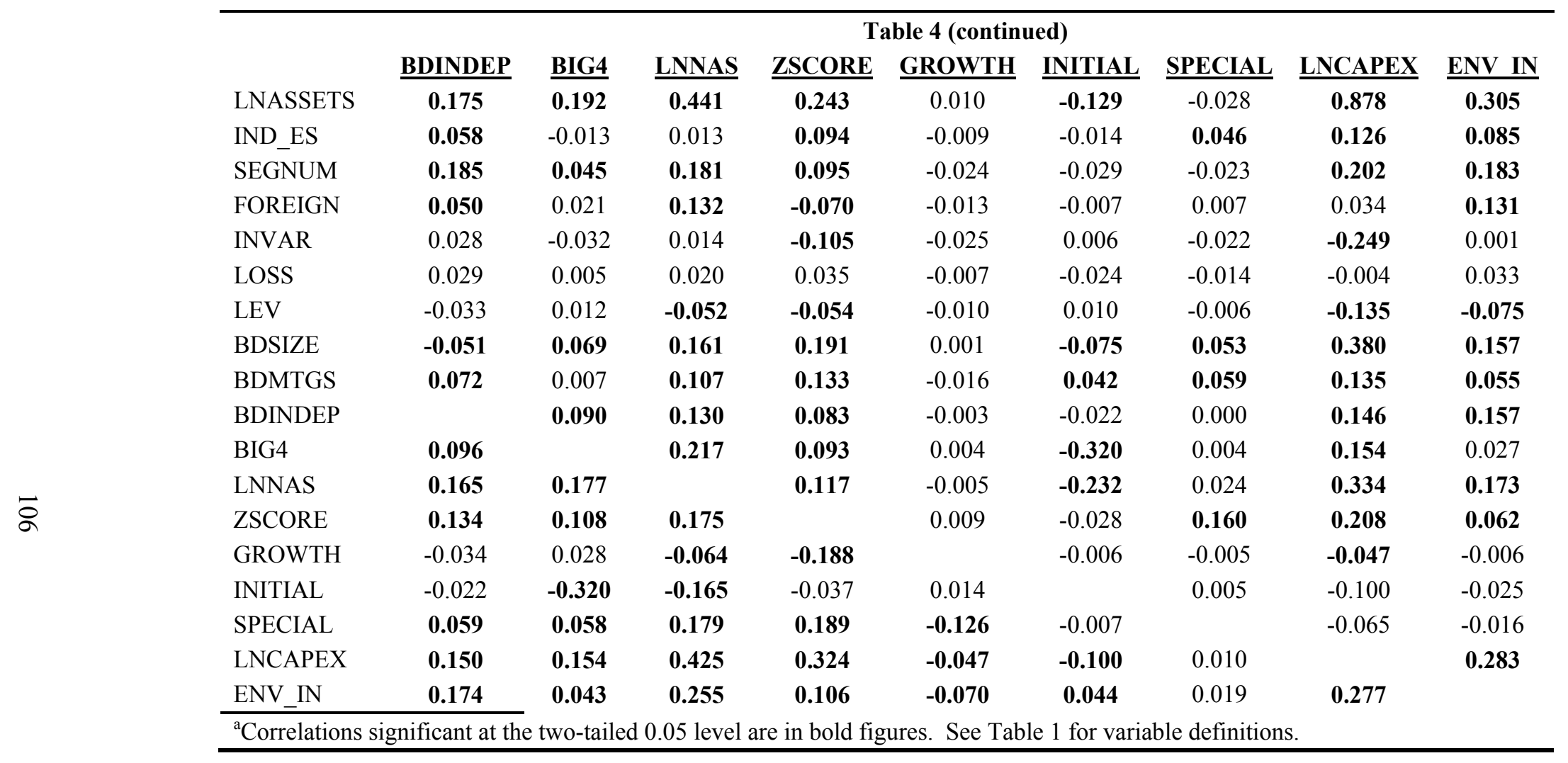


Table 5

Regression of Audit Fees on Environmental Initiatives

LNAUDFEE $=f\{$ LNASSETS, IND_ES, SEGNUM, FOREIGN, INVAR, LOSS, LEV, BDSIZE, BDMTGS, BDINDEP, BIG4, LNNAS, ZSCORE, GROWTH, INITIAL, SPECIAL, ENV_IN, YEAR FIXED EFFECTS \}

\begin{tabular}{lccc} 
Variable & Expected & Estimate & \\
\cline { 2 - 3 } Intercept & $\underline{\text { Sign }}$ & & t-statistic \\
LNASSETS & $?$ & 7.658 & $55.637 * * *$ \\
IND_ES & + & 0.456 & $42.732^{* * *}$ \\
SEGNUM & $?$ & -0.105 & $3.629 * * *$ \\
FOREIGN & + & 0.012 & $5.212^{* * *}$ \\
INVAR & + & 0.328 & $13.080^{* * *}$ \\
LOSS & + & 0.992 & $12.893^{* * *}$ \\
LEV & + & -0.033 & 0.927 \\
BDSIZE & + & 0.091 & $1.862^{* *}$ \\
BDMTGS & $?$ & 0.004 & 0.860 \\
BDINDEP & $?$ & 0.018 & $5.012^{* * *}$ \\
BIG4 & $?$ & 0.213 & $2.800^{* * *}$ \\
LNNAS & + & 0.128 & $2.167 * *$ \\
ZSCORE & $?$ & 0.037 & $8.300^{* * *}$ \\
GROWTH & + & 0.020 & $2.477 * * *$ \\
INITIAL & + & -0.173 & $3.761 * * *$ \\
SPECIAL & $?$ & -0.077 & $1.875^{* *}$ \\
ENV_IN & + & 1.834 & $4.616^{* * * *}$ \\
YEAR FIXED EFFECTS & & $\mathbf{0 . 1 2 9}$ & $\mathbf{4 . 2 5 8 * * *}$ \\
& & yes &
\end{tabular}

Observations

2,474

Adjusted $\mathrm{R}^{2} / \mathrm{F}$-value

VIF Range

$1.023-2.199$

***,**,* denote significance at the $0.01,0.05,0.10$ levels, respectively. The t-statistics are based on White's (1980) adjusted standard errors. See Table 1 for variable definitions. 


\begin{tabular}{|c|c|c|c|c|c|}
\hline \multicolumn{6}{|c|}{ Table 6} \\
\hline \multicolumn{6}{|c|}{$\begin{array}{c}\text { Regression of Audit Fees on } \\
\text { Environmental Initiative Indicator and Types of Initiatives }\end{array}$} \\
\hline \multicolumn{6}{|c|}{$\begin{aligned} \text { LNAUDFEE }=f & \text { \{LNASSETS, IND_ES, SEGNUM, FOREIGN, INVAR, LOSS, LEV, } \\
& \text { BDSIZE, BDMTGS, BDINDEP, BIG4, LNNAS, ZSCORE, GROWTH, } \\
& \text { INITIAL, SPECIAL, ENV_YN (or INITIATIVE TYPES), YEAR FIXED } \\
& \text { EFFECTS }\}\end{aligned}$} \\
\hline \multirow[b]{2}{*}{$\underline{\text { Variable }}$} & \multirow[b]{2}{*}{ Expected Sign } & \multicolumn{2}{|c|}{ ENV_YN } & \multicolumn{2}{|c|}{ INITIATIVE TYPES } \\
\hline & & Estimate & t-statistic & Estimate & t-statistic \\
\hline Intercept & $?$ & 7.656 & $55.68 * * *$ & 7.647 & $55.194 * * *$ \\
\hline LNASSETS & + & 0.456 & $42.75^{* * *}$ & 0.458 & $42.619 * * *$ \\
\hline IND_ES & $?$ & -0.105 & $3.61 * * *$ & -0.101 & $3.81 * * *$ \\
\hline SEGNUM & + & 0.012 & $5.35 * * *$ & 0.012 & $5.03 * * *$ \\
\hline FOREIGN & + & 0.329 & $13.15^{* * *}$ & 0.321 & $12.76^{* * *}$ \\
\hline INVAR & + & 0.994 & $12.92 * * *$ & 0.981 & $12.73 * * *$ \\
\hline LOSS & + & -0.031 & 0.88 & -0.033 & 0.92 \\
\hline LEV & + & 0.092 & $1.90 * *$ & 0.091 & $1.86^{* *}$ \\
\hline BDSIZE & $?$ & 0.004 & 0.86 & 0.004 & 0.86 \\
\hline BDMTGS & $?$ & 0.018 & $5.04 * * *$ & 0.018 & $4.99 * * *$ \\
\hline BDINDEP & $?$ & 0.208 & $2.74 * * *$ & 0.218 & $2.87 * * *$ \\
\hline BIG4 & + & 0.127 & $2.14 * *$ & 0.125 & $2.12 * *$ \\
\hline LNNAS & $?$ & 0.037 & $8.27 * * *$ & 0.037 & $8.20 * * *$ \\
\hline ZSCORE & + & 0.020 & $2.42 * * *$ & 0.022 & $2.61 * * *$ \\
\hline GROWTH & + & -0.172 & $3.75^{* * *}$ & -0.170 & $3.70 * * *$ \\
\hline INITIAL & $?$ & -0.076 & $1.83 * *$ & -0.081 & $1.97 * *$ \\
\hline SPECIAL & + & 1.830 & $4.61 * * *$ & 1.806 & $4.55^{* * *}$ \\
\hline ENV_YN & $?$ & 0.170 & $4.30 * * *$ & & \\
\hline PROD_SERV & $?$ & & & 0.186 & $2.67 * * *$ \\
\hline POLL_PREV & $?$ & & & 0.228 & $2.81 * * *$ \\
\hline RECYCLE & $?$ & & & 0.022 & 0.25 \\
\hline CLIMATE & $?$ & & & -0.009 & 0.16 \\
\hline OTHER & $?$ & & & 0.219 & $2.77 * * *$ \\
\hline YEAR FIXED I & FFECTS & yes & & yes & \\
\hline Observations & & 2,474 & & & \\
\hline Adj. $R^{2} / F$-value & & 0.70 & $297.3 * * *$ & 0.70 & $246.67 * * *$ \\
\hline VIF Range & & $1.023-2$ & & $1.025-2$ & \\
\hline
\end{tabular}




\begin{tabular}{|c|c|c|c|c|c|}
\hline & & & & & \\
\hline Regression of & Idit Fees on & ironmental & tiatives Conc & nal on Capital & Expenditure \\
\hline LNAUDFEE $=f$ & $\begin{array}{l}\text { NASSETS, I } \\
\text { DSIZE, BD } \\
\text { NITIAL, SPI } \\
\text { NV_YN*LN }\end{array}$ & $\begin{array}{l}\text { ES, SEGNL } \\
\text { IS, BDINDF } \\
\text { AL, ENV_Y] } \\
\text { PEX), YEA }\end{array}$ & $\begin{array}{l}\text { FOREIGN, } \\
\text { BIG4, LNNA } \\
\text { NCAPEX (o } \\
\text { IXED EFFEC }\end{array}$ & $\begin{array}{l}\text { AR, LOSS, LE } \\
\text { SCORE, GRO } \\
\text { JV_YN, LNCA }\end{array}$ & $\begin{array}{l}\text { TH, } \\
\text { EX, }\end{array}$ \\
\hline & & $\begin{array}{l}\text { Environm } \\
\text { and Capit }\end{array}$ & $\begin{array}{l}\text { al Initiative } \\
\text { Expenditure }\end{array}$ & $\begin{array}{l}\text { Environme } \\
\text { Capital Expe }\end{array}$ & $\begin{array}{l}\text { al Initiative and } \\
\text { diture Interaction }\end{array}$ \\
\hline Variable & $\frac{\text { Expected }}{\text { Sign }}$ & $\underline{\text { Estimate }}$ & $\underline{\text { t-statistic }}$ & $\underline{\text { Estimate }}$ & $\underline{\text { t-statistic }}$ \\
\hline Intercept & $?$ & 6.930 & $40.71 * * *$ & 7.047 & $40.99 * * *$ \\
\hline LNASSETS $^{\mathrm{a}}$ & + & 0.555 & $31.71 * * *$ & 0.549 & $31.38^{* * *}$ \\
\hline IND_ES & $?$ & -0.076 & $2.63 * * *$ & -0.076 & $2.63^{* * *}$ \\
\hline SEGNUM & + & 0.012 & $5.27 * * *$ & 0.012 & $5.23 * * *$ \\
\hline FOREIGN & + & 0.318 & $12.81 * * *$ & 0.315 & $12.71^{* * *}$ \\
\hline INVAR & + & 0.912 & $11.84 * * *$ & 0.903 & $11.76^{* * *}$ \\
\hline LOSS & + & -0.041 & 1.17 & -0.045 & $1.28^{*}$ \\
\hline LEV & + & 0.079 & $1.63^{* *}$ & 0.077 & $1.60^{* *}$ \\
\hline BDSIZE & $?$ & 0.004 & 0.95 & 0.004 & 0.85 \\
\hline BDMTGS & $?$ & 0.017 & $4.71^{* * *}$ & 0.017 & $4.71 * * *$ \\
\hline BDINDEP & $?$ & 0.210 & $2.79 * * *$ & 0.194 & $2.58^{* * *}$ \\
\hline BIG4 & + & 0.123 & $2.10^{* *}$ & 0.122 & $2.08 * *$ \\
\hline LNNAS & $?$ & 0.035 & $7.81 * * *$ & 0.034 & $7.76^{* * *}$ \\
\hline ZSCORE & + & 0.020 & $2.42 * * *$ & 0.022 & $2.66^{* * *}$ \\
\hline GROWTH & + & -0.160 & $3.51^{* * *}$ & -0.159 & $3.50^{* * *}$ \\
\hline INITIAL & $?$ & -0.071 & $1.74 * *$ & -0.069 & $1.71 * *$ \\
\hline SPECIAL & + & 1.514 & $3.83 * * *$ & 1.441 & $3.65^{* * *}$ \\
\hline ENV_YN & $?$ & 0.183 & $4.67 * * *$ & -0.142 & $1.65^{*}$ \\
\hline LNCAPEX & + & 0.458 & 43.35*** & 0.448 & $41.52 * * *$ \\
\hline $\begin{array}{l}\text { ENV_YN*LNCAP } \\
\text { EX }\end{array}$ & + & & & 0.060 & $4.21 * * *$ \\
\hline YEAR FIXED EF & CTS & yes & & yes & \\
\hline Observations & & 2,474 & & & \\
\hline Adj. $R^{2} / F$-val. & & 0.70 & $290.7 * * *$ & 0.70 & $279.6^{* * *}$ \\
\hline VIF Range & & $1.024-$ & & 1.02 & -6.177 \\
\hline $\begin{array}{l}* * *, * *, * \text { denote } \\
\text { White's }(1980) \text { ad } \\
\text { a For the second an } \\
\text { as a variable of int } \\
\text { EI_YN }=1 \text { if a fir } \\
\text { the natural logarit } \\
\text { two aforementione }\end{array}$ & $\begin{array}{l}\text { nificance at } \\
\text { ted standard } \\
\text { hird models } \\
\text { st in the mo } \\
\text { is involved i } \\
\text { of total ca } \\
\text { jariables. Se }\end{array}$ & $\begin{array}{l}0.01,0.05,0 \\
\text { rs. } \\
\text { ein, LNASS } \\
\text { least one en } \\
\text { expenditure } \\
\text { able } 1 \text { for otl }\end{array}$ & $\begin{array}{l}\text { levels, respe } \\
\text { excludes car } \\
\text { nmental initi } \\
\text { hd EI_YN*L } \\
\text { variable defin }\end{array}$ & $\begin{array}{l}\text { ely. The t-stati } \\
\text { expenditure as } \\
\text {, and } 0 \text { otherw } \\
\text { PPEX = intera } \\
\text { hs. }\end{array}$ & $\begin{array}{l}\text { tics are based on } \\
\text { hey are included } \\
\text { se; LNCAPEX = } \\
\text { ion term for the }\end{array}$ \\
\hline
\end{tabular}




\begin{tabular}{|c|c|c|}
\hline \multicolumn{3}{|c|}{$\begin{array}{c}\text { TABLE 8 } \\
\text { Essay Two Variable Definitions }\end{array}$} \\
\hline Variable Name & $\begin{array}{l}\text { Expected } \\
\text { Sign }\end{array}$ & Variable Measurement \\
\hline \multicolumn{3}{|c|}{ Panel A: Dependent Variable } \\
\hline LNCAPEX & & Natural logarithm of capital expenditures (Compustat) \\
\hline \multicolumn{3}{|c|}{ Panel B: Test Variable } \\
\hline ENV_IN & + & $\begin{array}{l}\text { Natural logarithm of the sum of the number of } \\
\text { environmental initiatives for a firm in a given year } \\
\text { (KLD). }\end{array}$ \\
\hline \multicolumn{3}{|c|}{ Panel C: Control Variables } \\
\hline LNASSETS & + & $\begin{array}{l}\text { Natural logarithm of total assets less capital } \\
\text { expenditures (Compustat). }\end{array}$ \\
\hline LEV & $?$ & Total debt to total assets (Compustat). \\
\hline LOSS & - & $\begin{array}{l}1 \text { if firms reports a loss in the fiscal year, and } 0 \\
\text { otherwise (Compustat). }\end{array}$ \\
\hline $\mathrm{OCF}$ & + & Operating cash flow scaled by total assets (Compustat). \\
\hline GROWTH & $?$ & $\begin{array}{l}\text { Percentage growth in sales over the prior year } \\
\text { (Compustat). }\end{array}$ \\
\hline FOREIGN & + & $\begin{array}{l}1 \text { if firm has foreign operations, and } 0 \text { otherwise } \\
\text { (Compustat). }\end{array}$ \\
\hline MERGER & + & $\begin{array}{l}1 \text { if firm was involved in a merger or acquisition in the } \\
\text { current year, and } 0 \text { otherswise (Compustat). }\end{array}$ \\
\hline AGE & + & $\begin{array}{l}\text { Natural logarithm of company age in years } \\
\text { (Compustat). }\end{array}$ \\
\hline BDINDEP & $?$ & $\begin{array}{l}\text { Proportion of board members who are independent } \\
\text { (Corporate Library). }\end{array}$ \\
\hline DUAL & $?$ & $\begin{array}{l}1 \text { if CEO also serves as board chairman, and } 0 \\
\text { otherwise (Corporate Library). }\end{array}$ \\
\hline ENV_CON & + & $\begin{array}{l}\text { Natural logarithm of the sum of the number of } \\
\text { environmental concerns (KLD). }\end{array}$ \\
\hline INDUSTRY & $?$ & $\begin{array}{l}\text { Ten portfolio industry dummy variables as defined by } \\
\text { Fama and French (2010). }\end{array}$ \\
\hline
\end{tabular}




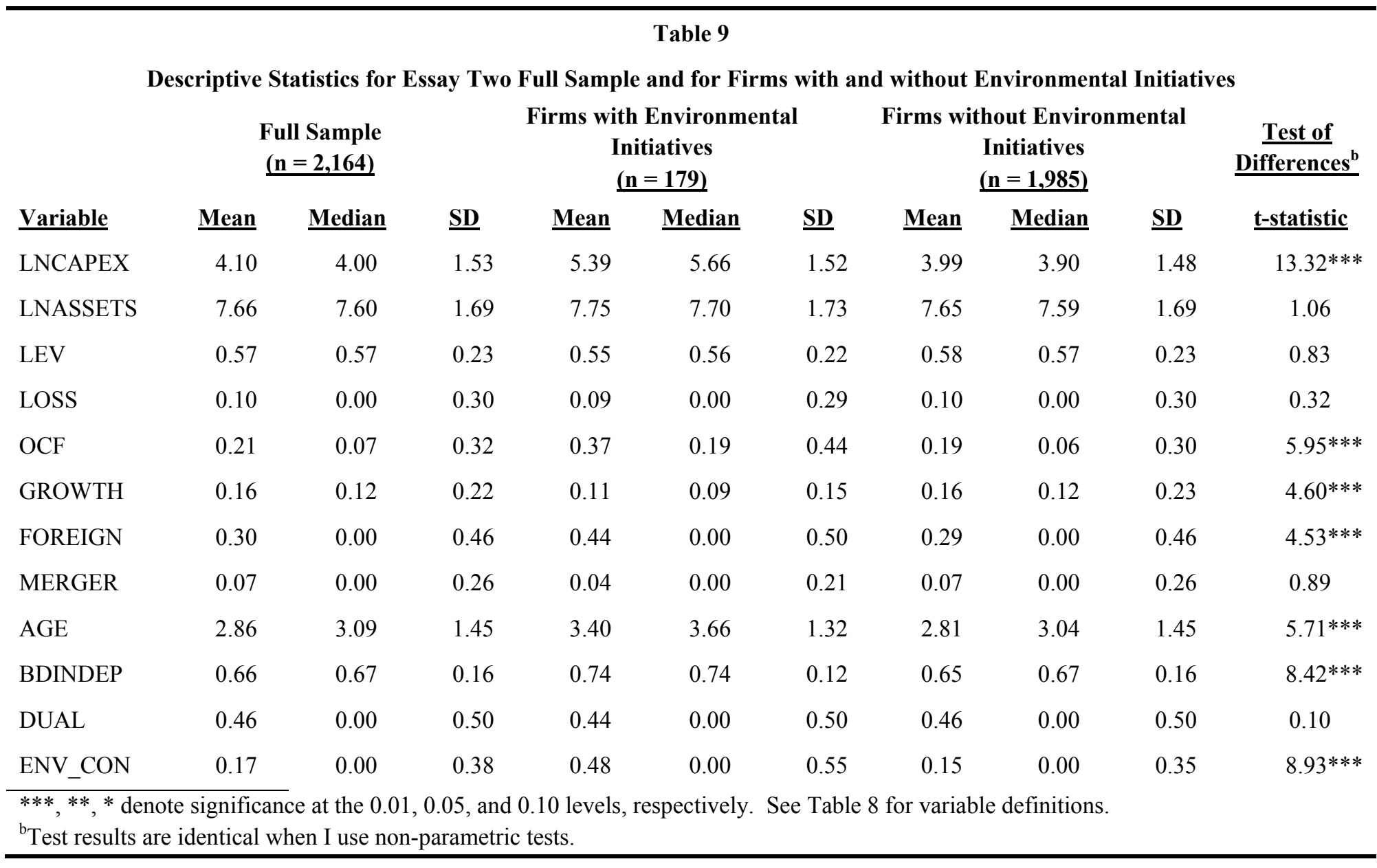




\begin{tabular}{|c|c|c|c|c|c|c|c|}
\hline \multicolumn{8}{|c|}{$\begin{array}{c}\text { Table 10 } \\
\text { Essay Two Pearson and Spearman Correlations } \\
\text { tions: Pearson (Spearman) Correlations are Presented in the Upper (Lower) Diagonal }{ }^{\mathrm{a}}\end{array}$} \\
\hline & LNASSETS & $\underline{\text { LEV }}$ & $\underline{\text { LOSS }}$ & $\underline{\mathrm{OCF}}$ & GROWTH & FOREIGN & MERGER \\
\hline LNASSETS & & 0.444 & -0.167 & -0.574 & 0.049 & 0.035 & 0.024 \\
\hline LEV & 0.456 & & 0.057 & -0.276 & 0.031 & -0.003 & 0.035 \\
\hline LOSS & -0.162 & 0.059 & & 0.106 & -0.035 & 0.000 & -0.025 \\
\hline OCF & -0.677 & -0.322 & 0.102 & & -0.048 & 0.027 & -0.016 \\
\hline GROWTH & 0.059 & 0.042 & -0.015 & -0.051 & & 0.020 & 0.115 \\
\hline FOREIGN & 0.031 & 0.000 & 0.000 & 0.001 & 0.030 & & 0.011 \\
\hline MERGER & 0.026 & 0.032 & -0.025 & -0.017 & 0.111 & 0.011 & \\
\hline AGE & -0.011 & -0.088 & 0.016 & 0.156 & -0.105 & 0.039 & -0.018 \\
\hline BDINDEP & 0.008 & -0.031 & 0.028 & 0.106 & -0.032 & 0.045 & -0.009 \\
\hline DUAL & -0.009 & 0.031 & -0.087 & 0.047 & 0.032 & -0.007 & 0.007 \\
\hline ENV_CON & 0.012 & -0.059 & 0.047 & 0.191 & -0.037 & 0.004 & 0.000 \\
\hline ENV_IN & 0.017 & -0.027 & -0.002 & 0.142 & -0.063 & 0.091 & -0.031 \\
\hline
\end{tabular}




\begin{tabular}{|c|c|c|c|c|c|}
\hline \multicolumn{6}{|c|}{ Table 10 (continued) } \\
\hline & $\underline{\mathbf{A G E}}$ & BDINDEP & $\underline{\text { DUAL }}$ & $\underline{\text { ENV CON }}$ & ENV IN \\
\hline LNASSETS & -0.005 & 0.007 & -0.011 & 0.016 & 0.014 \\
\hline LEV & -0.079 & -0.026 & 0.040 & -0.055 & -0.026 \\
\hline LOSS & 0.019 & 0.025 & -0.087 & 0.040 & 0.002 \\
\hline OCF & 0.124 & 0.093 & 0.028 & 0.197 & 0.175 \\
\hline GROWTH & -0.101 & -0.034 & 0.024 & -0.022 & -0.061 \\
\hline FOREIGN & 0.046 & 0.051 & -0.007 & 0.011 & 0.095 \\
\hline MERGER & -0.011 & -0.012 & 0.007 & 0.001 & -0.031 \\
\hline AGE & & 0.088 & -0.004 & 0.039 & 0.115 \\
\hline BDINDEP & 0.091 & & 0.023 & 0.168 & 0.151 \\
\hline DUAL & 0.006 & 0.025 & & 0.041 & -0.015 \\
\hline ENV_CON & 0.046 & 0.157 & 0.040 & & 0.233 \\
\hline ENV_IN & 0.117 & 0.150 & -0.014 & 0.229 & \\
\hline
\end{tabular}




\section{Table 11}

Hypothesis 1: Regression of Capital Expenditures on Environmental Initiatives LNCAPEX $=f$ LNASSETS, LEV, LOSS, OCF, GROWTH, FOREIGN, MERGER, AGE, BDINDEP, DUAL, ENV_CON, ENV_IN, INDUSTRY\}

\begin{tabular}{lccc} 
Variable & Expected Sign & Estimate & $\frac{\text { t-statistic }}{\text { Intercept }}$ \\
\cline { 2 - 2 } & $?$ & 1.342 & $6.835^{* * *}$ \\
LNAS & + & 0.170 & $8.571^{* * *}$ \\
LOSS & $?$ & 0.442 & $3.603^{* * *}$ \\
OCF & - & -0.260 & $-3.058^{* * *}$ \\
GROWTH & + & 2.183 & $21.611^{* * *}$ \\
FOREIGN & $?$ & -0.056 & -0.497 \\
MERGER & + & 0.154 & $2.727^{* * *}$ \\
AGE & + & -0.069 & -0.718 \\
BDINDEP & + & 0.126 & $7.114^{* * *}$ \\
DUAL & $?$ & 0.428 & $2.579^{* * *}$ \\
ENV_CON & $?$ & 0.135 & $2.733^{* * *}$ \\
ENV_IN & + & 0.632 & $8.207^{* * *}$ \\
INDUSTRY & + & $\mathbf{0 . 7 6 4}$ & $\mathbf{6 . 7 1 4 * * *}$
\end{tabular}

Observations $\quad 2,164$

Adjusted $\mathrm{R}^{2} / \mathrm{F}$-value $\quad \mathbf{0 . 4 6}$

$87.273 * * *$

VIF Range $\quad 1.020-1.913$

***,**, * denote significance at the $0.01,0.05,0.10$ levels, respectively. The t-statistics are based on White's (1980) adjusted standard errors. See Table 8 for variable definitions. 
Table 12

Hypothesis 1 Additional Testing: Regression of Capital Expenditures on Any Environmental Initiative Participation

LNCAPEX $=\quad \mathrm{f}\{$ LNASSETS, LEV, LOSS, OCF, GROWTH, FOREIGN, MERGER, AGE, BDINDEP, DUAL, ENV_CON, ENV_YN, INDUSTRY\}

\begin{tabular}{lccc} 
Variable & Expected Sign & Estimate & t-statistic \\
\cline { 2 - 3 } & $?$ & 1.364 & $6.973^{* * *}$ \\
LNASSETS & + & 0.169 & $8.531^{* * *}$ \\
LEV & $?$ & 0.433 & $3.549 * * *$ \\
LOSS & - & -0.253 & $-2.986^{* * *}$ \\
OCF & + & 2.171 & $21.594^{* * *}$ \\
GROWTH & $?$ & -0.041 & -0.366 \\
FOREIGN & + & 0.149 & $2.649 * * *$ \\
MERGER & + & -0.079 & -0.826 \\
AGE & + & 0.124 & $7.003^{* * *}$ \\
BDINDEP & $?$ & 0.431 & $2.610^{* * *}$ \\
DUAL & $?$ & 0.130 & $2.650^{* * *}$ \\
ENV_CON & + & 0.601 & $7.797 * * *$ \\
ENV_YN & + & $\mathbf{0 . 6 9 8}$ & $\mathbf{7 . 8 4 5 * * *}$ \\
INDUSTRY & + & yes &
\end{tabular}

Observations $\quad 2,164$

Adjusted $\mathrm{R}^{2} / \mathrm{F}$-value $\quad \mathbf{0 . 4 6}$

$88.698 * * *$

VIF Range

$1.020-1.913$

***,**,* denote significance at the $0.01,0.05,0.10$ levels, respectively. The t-statistics are based on White's (1980) adjusted standard errors. See Table 8 for variable definitions. 
Table 13

Hypothesis 2: Regression of Capital Expenditures on Environmental Initiative Types

$\begin{aligned} \text { LNCAPEX }= & \mathrm{f}\{\text { LNASSETS, LEV, LOSS, OCF, GROWTH, FOREIGN, MERGER, AGE, } \\ & \text { BDINDEP, DUAL, ENV_CON, PROD_SERV, POLL_PREV, RECYCLE, } \\ & \text { CLIMATE, OTHER, INDUSTRY }\}\end{aligned}$

$\begin{array}{lccc}\text { Variable } & \text { Expected } & \text { Estimate } & \frac{\text { t-statistic }}{\text { Sign }} \\ \text { Intercept } & & 1.337 & 6.789^{* * *} \\ \text { LNASSETS } & + & 0.169 & 8.523^{* * *} \\ \text { LEV } & ? & 0.438 & 3.577^{* * *} \\ \text { LOSS } & - & -0.267 & -3.145^{* * *} \\ \text { OCF } & + & 2.178 & 21.441^{* * *} \\ \text { GROWTH } & ? & -0.058 & -0.514 \\ \text { FOREIGN } & + & 0.161 & 2.843^{* * *} \\ \text { MERGER } & + & -0.065 & -0.676 \\ \text { AGE } & + & 0.128 & 7.227^{* * *} \\ \text { BDINDEP } & ? & 0.445 & 2.679^{* * *} \\ \text { DUAL } & + & 0.140 & 2.822^{* * *} \\ \text { ENV_CON } & + & 0.617 & 7.952^{* * *} \\ \text { PROD_SERV } & + & \mathbf{0 . 0 5 4} & \mathbf{0 . 3 4 4} \\ \text { POLL_PREV } & + & \mathbf{0 . 2 1 0} & \mathbf{1 . 0 8 7} \\ \text { RECYCLE } & + & \mathbf{0 . 8 0 8} & \mathbf{3 . 8 4 3 * * * *} \\ \text { CLIMATE } & + & \mathbf{0 . 6 2 4} & \mathbf{3 . 8 7 7 * * *} \\ \text { OTHER } & + & \mathbf{0 . 5 5 2} & \mathbf{2 . 8 0 7 * * * *} \\ \text { INDUSTRY } & & \text { yes } & \end{array}$

Observations $\quad 2,164$

Adjusted $\mathrm{R}^{2} /$ F-value $\quad \mathbf{0 . 4 6}$

$74.673 * * *$

VIF Range $\quad 1.026-1.734$

$* * *, * *, *$ denote significance at the $0.01,0.05,0.10$ levels, respectively. The $\mathrm{t}$-statistics are based on White's (1980) adjusted standard errors. See Table 8 for variable definitions. 


\begin{tabular}{|c|c|c|}
\hline \multicolumn{3}{|c|}{$\begin{array}{c}\text { TABLE } 14 \\
\text { Essay Three Variable Definitions }\end{array}$} \\
\hline Variable Name & $\begin{array}{l}\text { Expected } \\
\text { Sign }\end{array}$ & Variable Measurement \\
\hline \multicolumn{3}{|c|}{ Panel A: Dependent Variables } \\
\hline AB_DACC & & $\begin{array}{l}\text { Absolute value of firm performance-adjusted modified- } \\
\text { Jones model discretionary accruals (Kothari et al. 2005). }\end{array}$ \\
\hline INC_DACC & & $\begin{array}{l}\text { Income-increasing firm performance-adjusted modified- } \\
\text { Jones model discretionary accruals (Kothari et al. 2005). }\end{array}$ \\
\hline \multicolumn{3}{|l|}{ Panel B: Test Variables } \\
\hline ENV_IN & - & $\begin{array}{l}\text { Sum of types of environmental initiatives for a firm in a } \\
\text { given year as reported by KLD Analytics. }\end{array}$ \\
\hline ENV_YN & - & $\begin{array}{l}1 \text { if a firm engages in at least one environmental initiative } \\
\text { as reported by KLD Analytics, and } 0 \text { otherwise. }\end{array}$ \\
\hline \multicolumn{3}{|c|}{ Panel B: Control Variables } \\
\hline LN_MVE & $?$ & Natural log of the market value of firm equity (Compustat). \\
\hline LEV & $?$ & Total debt to total assets (Compustat). \\
\hline MKTBK & + & $\begin{array}{l}\text { Market value of equity divided by book value of equity } \\
\text { (Compustat). }\end{array}$ \\
\hline LOSS & + & $\begin{array}{l}1 \text { if firms reports a loss in the fiscal year, and } 0 \text { otherwise } \\
\text { (Compustat). }\end{array}$ \\
\hline $\mathrm{OCF}$ & - & $\begin{array}{l}\text { Operating cash flow scaled by beginning of year total assets } \\
\text { (Compustat). }\end{array}$ \\
\hline LAG_TOTACC & - & $\begin{array}{l}\text { Last year's total accruals scaled by beginning of year total } \\
\text { assets (Compustat). }\end{array}$ \\
\hline BIG4 & - & $\begin{array}{l}1 \text { if firm is audited by a Big } 4 \text {, and } 0 \text { otherwise } \\
\text { (Compustat). }\end{array}$ \\
\hline MERGER & $?$ & $\begin{array}{l}1 \text { if firm was involved in a merger or acquisition in the } \\
\text { current year, and } 0 \text { otherswise (Compustat). }\end{array}$ \\
\hline LITIGATION & + & $\begin{array}{l}1 \text { if the firm is in a high litigation risk industry identified by } \\
\text { Francis et al. (1994) as SIC's } 2833-2836,3570-3577,3600- \\
3674,5200-5961,7370-7374 \text {, and } 0 \text { otherwise. } \\
\text { (Compustat). }\end{array}$ \\
\hline ACEXP & - & $\begin{array}{l}1 \text { if audit committee contains at least one accounting expert, } \\
\text { and } 0 \text { otherwise (Corporate Library and proxy statements). }\end{array}$ \\
\hline YEAR FIXED EFFECTS & & Year dummies. \\
\hline INDUSTRY & & $\begin{array}{l}\text { Ten portfolio industry dummy variables as defined by Fama } \\
\text { and French (2010). }\end{array}$ \\
\hline
\end{tabular}




\begin{tabular}{|c|c|c|c|c|c|c|c|c|c|c|}
\hline \multicolumn{11}{|c|}{ Table 15} \\
\hline LN_MVE & 21.39 & 21.21 & 1.36 & 21.44 & 21.27 & 1.35 & 21.34 & 21.15 & 1.36 & $1.78^{*}$ \\
\hline LEV & 0.56 & 0.55 & 0.23 & 0.57 & 0.56 & 0.23 & 0.55 & 0.54 & 0.23 & 1.44 \\
\hline MKTBK & 1.33 & 1.04 & 1.14 & 1.31 & 1.00 & 1.16 & 1.36 & 1.09 & 1.11 & 1.04 \\
\hline LAG_TOTACC & 0.00 & 0.00 & 0.00 & 0.00 & 0.00 & 0.00 & 0.00 & 0.00 & 0.00 & 0.21 \\
\hline BIG4 & 0.96 & 1.00 & 0.20 & 0.95 & 1.00 & 0.22 & 0.96 & 1.00 & 0.19 & $1.71^{* *}$ \\
\hline MERGER & 0.06 & 0.00 & 0.24 & 0.07 & 0.00 & 0.25 & 0.05 & 0.00 & 0.22 & 1.55 \\
\hline LITIGATION & 0.21 & 0.00 & 0.41 & 0.25 & 0.00 & 0.43 & 0.19 & 0.00 & 0.37 & $4.63 * * *$ \\
\hline ACEXP & 0.71 & 1.00 & 0.46 & 0.71 & 1.00 & 0.46 & 0.71 & 1.00 & 0.45 & 0.20 \\
\hline ENV_IN & 0.13 & 0.00 & 0.40 & 0.11 & 0.00 & 0.38 & 0.14 & 0.00 & 0.42 & $1.39^{*}$ \\
\hline
\end{tabular}




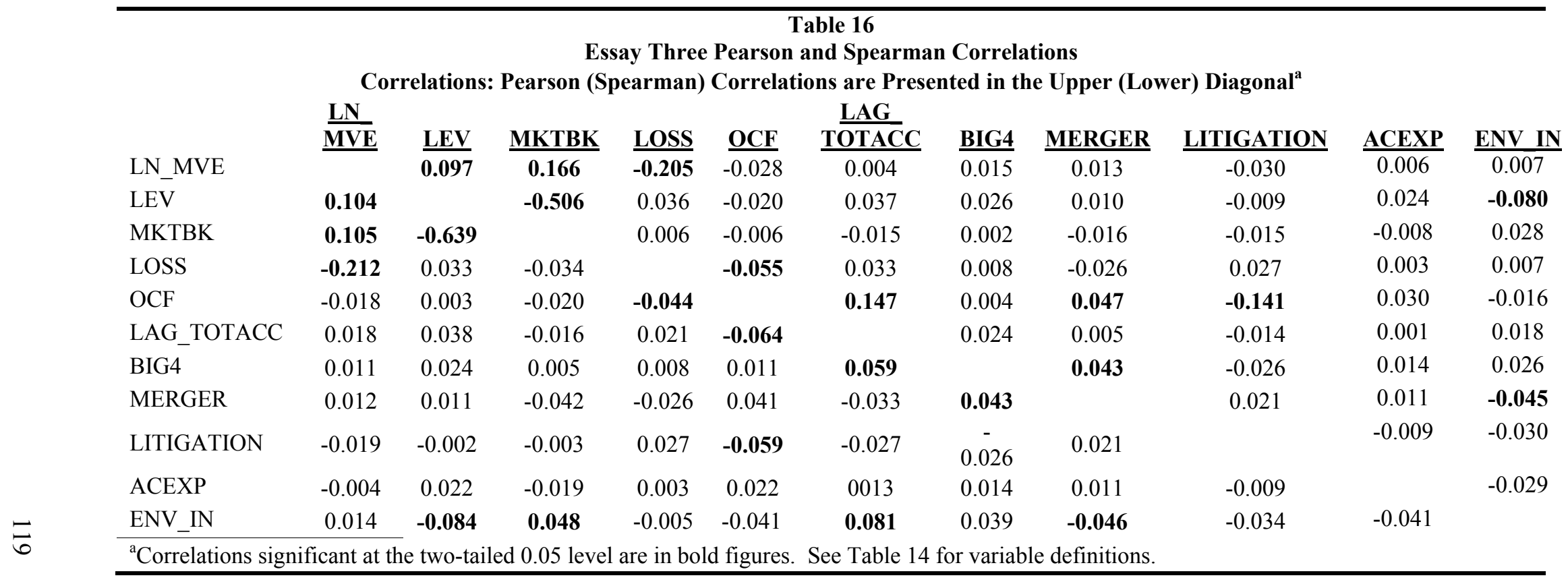


Table 17

Regression of Absolute Value of Discretionary Accruals on Environmental Initiatives

\begin{tabular}{|c|c|c|c|}
\hline $\mathrm{AB} \_\mathrm{DACC}=$ & \multicolumn{3}{|c|}{$\begin{array}{l}f\{\text { LN_MVE, LEV, MKTBK, LOSS, OCF, LAG_TOTACC, BIG4, MERGER, } \\
\text { LITIGATION, ACEXP, ENV_IN, YEAR FIXED EFFECTS, INDUSTRY }\}\end{array}$} \\
\hline Variable & $\frac{\text { Expected }}{\text { Sian }}$ & Estimate & $\underline{\text { t-statistic }}$ \\
\hline Intercept & & 0.047 & 1.308 \\
\hline LN_MVE & $?$ & 0.002 & 1.331 \\
\hline LEV & $?$ & -0.023 & $-2.077^{* *}$ \\
\hline MKTBK & + & 0.002 & 0.797 \\
\hline LOSS & + & 0.012 & $1.719 * *$ \\
\hline OCF & - & -0.102 & $-4.792 * * *$ \\
\hline LAG_TOTACC & - & -5.181 & $-1.502 *$ \\
\hline BIG4 & - & 0.000 & -0.026 \\
\hline MERGER & $?$ & 0.006 & 0.664 \\
\hline LITIGATION & + & 0.021 & $3.284 * * *$ \\
\hline ACEXP & - & 0.000 & -0.041 \\
\hline ENV_IN & - & -0.012 & $-2.224 * *$ \\
\hline \multicolumn{4}{|l|}{ YEAR FIXED } \\
\hline EFFECTS & \multicolumn{3}{|c|}{ yes } \\
\hline INDUSTRY & & yes & \\
\hline
\end{tabular}

Observations

2,095

Adjusted $\mathrm{R}^{2} / \mathrm{F}$-value

0.10

$11.091 * * *$

VIF Range

$1.021-1.536$

$* * *, * * *$ denote significance at the $0.01,0.05,0.10$ levels, respectively. The t-statistics are based on White's (1980) adjusted standard errors. See Table 14 for variable definitions. 
Table 18

Regression of Income-Increasing Discretionary Accruals on Environmental Initiatives

INC_DACC $=f\{$ LN_MVE, LEV, MKTBK, LOSS, OCF, LAG_TOTACC, BIG4, MERGER, LITIGATION, ACEXP, ENV_IN, YEAR FIXĒD EFFECTS, INDUSTRY \}

$\begin{array}{lccc}\text { Variable } & \text { Expected } & \underline{\text { Estimate }} & \underline{\text { t-statistic }} \\ \text { Intercept } & \underline{\text { Sign }} & 0.061 & 0.993 \\ \text { LN_MVE } & ? & 0.002 & 0.654 \\ \text { LEV } & ? & -0.033 & -1.719^{*} \\ \text { MKTBK } & + & 0.003 & 0.732 \\ \text { LOSS } & + & 0.022 & 1.861^{* *} \\ \text { OCF } & - & -0.195 & -5.406^{* * *} \\ \text { LAG_TOTACC } & - & -20.606 & -3.822^{* * *} \\ \text { BIG4 } & - & 0.004 & 0.246 \\ \text { MERGER } & ? & -0.017 & -1.041 \\ \text { LITIGATION } & + & 0.029 & 2.600^{* * *} \\ \text { ACEXP } & - & 0.003 & 0.377 \\ \text { ENV_IN } & - & \mathbf{- 0 . 0 1 5} & \mathbf{- 1 . 4 9 7 ^ { * }} \\ \text { YEAR FIXED } & & & \\ \text { EFFECTS } & & \text { yes } & \\ \text { INDUSTRY } & & \text { yes } & \end{array}$

Observations

927

Adjusted $\mathrm{R}^{2} / \mathrm{F}$-value

0.13

$7.355^{* * *}$

VIF Range

$1.038-1.502$

$* * *, * * *$ denote significance at the $0.01,0.05,0.10$ levels, respectively. The t-statistics are based on White's (1980) adjusted standard errors. See Table 14 for variable definitions. 


\begin{tabular}{|c|c|c|c|}
\hline \multicolumn{4}{|c|}{$\begin{array}{c}\text { Table } 19 \\
\text { Reorecsion of }\end{array}$} \\
\hline \multirow{2}{*}{$\begin{array}{l}\text { AB_DACC = } \\
\text { Variable }\end{array}$} & \multicolumn{3}{|c|}{$\begin{array}{l}f\{\text { LN_MVE, LEV, MKTBK, LOSS, OCF, LAG_TOTACC, BIG4, MERGER, } \\
\text { LITIGATION, ACEXP, ENV_YN, YEAR FIXED EFFECTS, INDUSTRY }\}\end{array}$} \\
\hline & $\frac{\text { Expected }}{\text { Sign }}$ & Estimate & $\underline{\text { t-statistic }}$ \\
\hline Intercept & & 0.034 & 0.940 \\
\hline LN_MVE & $?$ & 0.002 & 1.328 \\
\hline LEV & $?$ & -0.023 & $-2.089 * *$ \\
\hline MKTBK & + & 0.002 & 0.814 \\
\hline LOSS & + & 0.012 & $1.699 * *$ \\
\hline $\mathrm{OCF}$ & - & -0.101 & $-4.785^{* * *}$ \\
\hline LAG_TOTACC & - & -5.153 & $-1.494 *$ \\
\hline BIG4 & - & 0.000 & 0.039 \\
\hline MERGER & $?$ & 0.006 & 0.727 \\
\hline LITIGATION & + & 0.021 & $3.316^{* * *}$ \\
\hline ACEXP & - & 0.000 & -0.067 \\
\hline ENV_YN & - & -0.016 & $-2.332 * * *$ \\
\hline \multicolumn{4}{|l|}{ YEAR FIXED } \\
\hline \multicolumn{4}{|l|}{ EFFECTS } \\
\hline INDUSTRY & & yes & \\
\hline Observations & 2,095 & & \\
\hline Adjusted $\mathrm{R}^{2} / \mathrm{F}$-value & 0.10 & & $11.116 * * *$ \\
\hline VIF Range & $1.020-1.537$ & & \\
\hline
\end{tabular}


Table 20

Regression of Income-Increasing Discretionary Accruals on Environmental Initiative Indicator

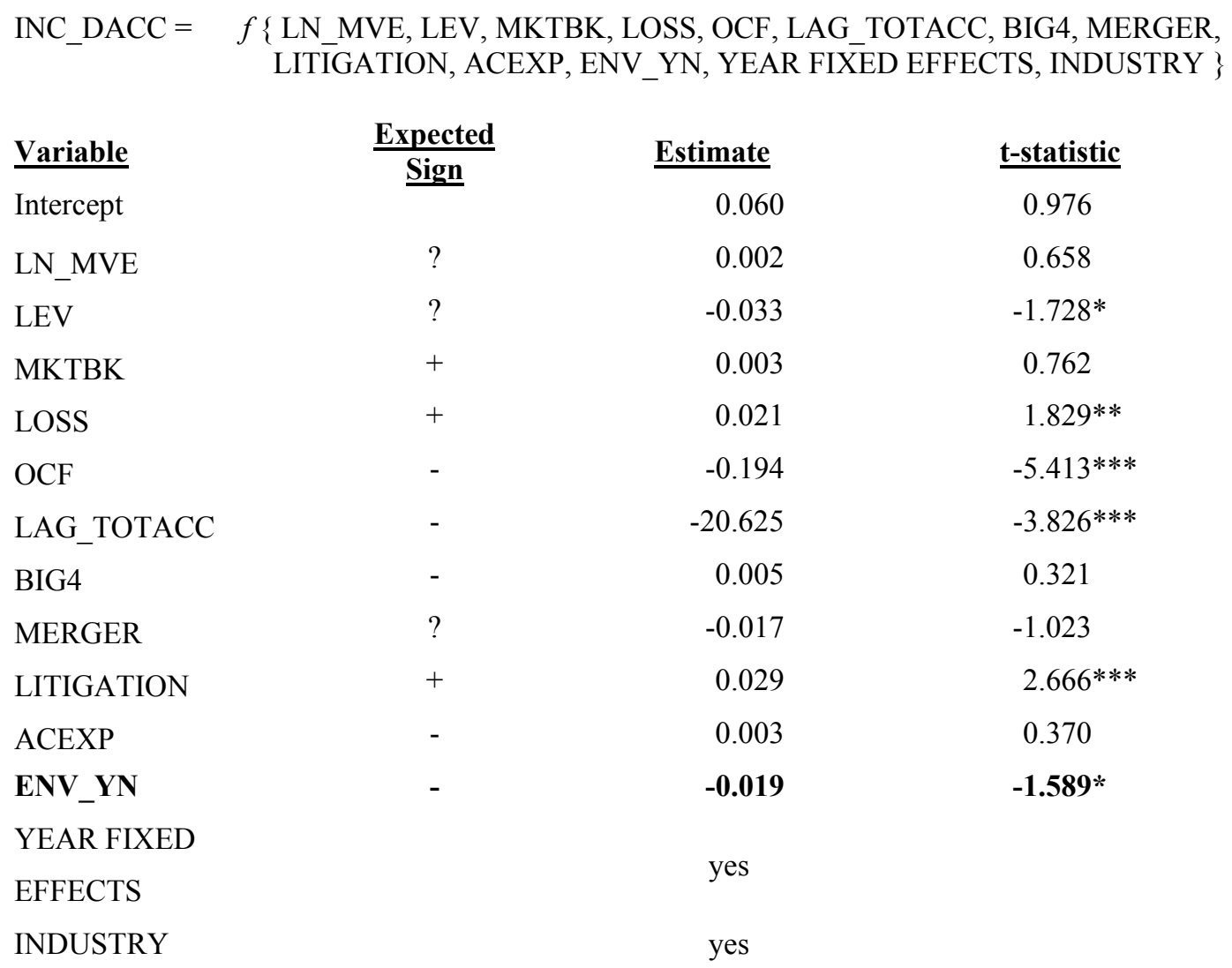

Observations

927

Adjusted $\mathrm{R}^{2} / \mathrm{F}$-value

0.13

$7.370 * * *$

VIF Range

$1.038-1.502$

$* * *, * * *$ denote significance at the $0.01,0.05,0.10$ levels, respectively. The t-statistics are based on White's (1980) adjusted standard errors. See Table 14 for variable definitions.. 
Table 21

Regression of Absolute Value of Discretionary Accruals on Types of Environmental Initiatives

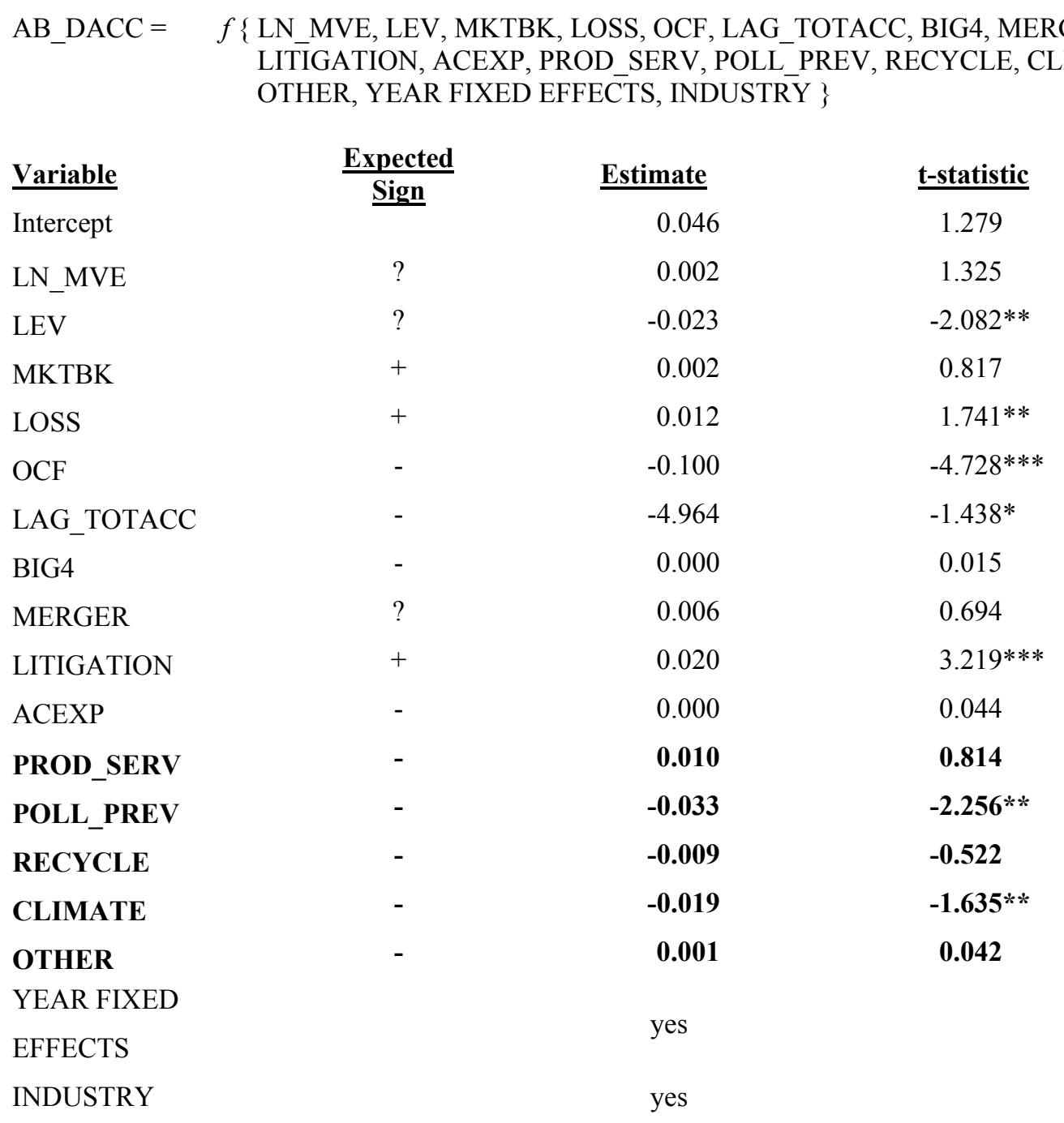

Observations

Adjusted $\mathrm{R}^{2} / \mathrm{F}$-value

VIF Range
2,095

0.10

$1.022-1.538$
$9.627 * * *$

$* * *, * * *$ denote significance at the $0.01,0.05,0.10$ levels, respectively. The t-statistics are based on White's (1980) adjusted standard errors. See Table 14 for variable definitions. 
Table 22

Regression of Income-Increasing Discretionary Accruals on Types of Environmental Initiatives

INC_DACC $=f\{$ LN_MVE, LEV, MKTBK, LOSS, OCF, LAG_TOTACC, BIG4, MERGER, LITIGATION, ACEXP, PROD_SERV, POLL_PREV, RECYCLE, CLIMATE, OTHER, YEAR FIXED EFFECTS, INDUSTRY \}

\begin{tabular}{|c|c|c|c|}
\hline$\underline{\text { Variable }}$ & $\frac{\text { Expected }}{\text { Sign }}$ & $\underline{\text { Estimate }}$ & $\underline{\text { t-statistic }}$ \\
\hline Intercept & & 0.058 & 0.949 \\
\hline LN_MVE & $?$ & 0.002 & 0.648 \\
\hline LEV & $?$ & -0.034 & $-1.775^{*}$ \\
\hline MKTBK & + & 0.003 & 0.730 \\
\hline LOSS & + & 0.021 & $1.817 * *$ \\
\hline $\mathrm{OCF}$ & - & -0.188 & $-5.218 * * *$ \\
\hline LAG_TOTACC & - & -20.179 & $-3.740 * * *$ \\
\hline BIG4 & - & 0.006 & 0.365 \\
\hline MERGER & $?$ & -0.018 & -1.062 \\
\hline LITIGATION & + & 0.027 & $2.415 * * *$ \\
\hline ACEXP & - & 0.004 & 0.459 \\
\hline PROD_SERV & - & 0.022 & 0.970 \\
\hline POLL_PREV & - & -0.042 & $-1.673 * *$ \\
\hline RECYCLE & - & -0.006 & -0.178 \\
\hline CLIMATE & - & -0.025 & -1.146 \\
\hline OTHER & - & 0.003 & 0.094 \\
\hline YEAR FIXED & \multirow{2}{*}{\multicolumn{3}{|c|}{ yes }} \\
\hline EFFECTS & & & \\
\hline INDUSTRY & \multicolumn{3}{|c|}{ yes } \\
\hline
\end{tabular}

Observations

927

Adjusted $\mathrm{R}^{2} / \mathrm{F}$-value

0.13

$6.390 * * *$

VIF Range

$$
1.039-1.507
$$

$* * *, * *, *$ denote significance at the $0.01,0.05,0.10$ levels, respectively. The t-statistics are based on White's (1980) adjusted standard errors. See Table 14 for variable definitions. 


\section{REFERENCES}

3M Company. 2006. 10-K Annual Report 2006.

Abarbanell, J., and R. Lehavy. 2003. Biased forecasts or biased earnings? The role of reported earnings in explaining apparent bias and over/underreaction in analysts' earnings forecasts. Journal of Accounting and Economics 36: 105-146.

Abel, A. B. 1983. Optimal investment under uncertainty. American Economic Review 73 (1): 228-233.

AICPA. 2006a. AU Section 314 Understanding the Entity and Its Environment and Assessing the Risks of Material Misstatement. Retrieved May 21, 2010, from ACIPA site. Available at http://www.aicpa.org/Research/Standards/AuditAttest/DownloadableDocuments/ AU-00314.pdf.

AICPA. 2006b. AU Section 550 Other information in Documents Containing Audited Financial Statements. Retrieved June 4, 2010, from ACIPA site. Available at http://www.aicpa.org/Research/Standards/AuditAttest/DownloadableDocuments/ AU-00550.pdf.

Aiken, L. S., and S. G. West. 1991. Multiple Regression: Testing and Interpreting Interactions. Newbury Park, CA: Sage.

Allen, M. P., E. M. Jamison, and M. J. Bennett. The Bureau of National Affairs. 2010. SEC Opens the Door for Climate Change-Related Shareholder Proposals and Disclosure Requirements, With Potential New Liabilities for Public Companies. Securities Regulation \& Law 0037-0665.

Allen, R. D., D. R. Hermanson, T. M. Kozloski, and R. J. Ramsay. 2006. Auditor risk assessment: Insights from the academic literature. Accounting Horizons 20 (2): 157-177.

Almeida, H., and M. Campello. 2007. Financial constraints, asset tangibility, and corporate investment. Review of Financial Studies 20: 1429-1460. 
Almeida, H., M. Campello, and M. S. Weisbach. 2004. The cash flow sensitivity of cash. The Journal of Finance 59 (4): 1777-1804.

Arens, A. A., R. J. Elder, and M. S. Beasley. 2010. Auditing and Assurance Services: An Integrated Approach. Prentice Hall: New Jersey.

Ashbaugh, H., R. LaFond, B. W. Mayhew. 2003. Do nonaudit services compromise auditor independence? Further evidence. The Accounting Review 78 (3): 611-639.

Audit Analytics. 2008. 2007 Financial restatements: A seven year comparison. www.auditanalytics.com.

Balabanis, G., H. C Phillips, and J. Lyall. 1998. Corporate social responsibility and economic performance in the top British companies: are they linked? European Business Review 98 (1): 25-44.

Bandler, J., and J. Hechinger. 2002. SEC Says Xerox Misled Its Investors and Conducted Improper Accounting. Wall Street Journal: April 12, 2002.

Bartkus B. R., and M. Glassman. 2008. Do firms practice what they preach? The relationship between mission statements and stakeholder management. Journal of Business Ethics 83 (2): 207-216.

Beasley, M. S. 1996. An empirical analysis of the relation between the board of director composition and financial statement fraud. The Accounting Review 71(October): 443-465.

Beasley, M. S., J. V. Carcello, and D. R. Hermanson. 1999. Fraudulent Financial Reporting: 1987-1997, An Analysis of U.S. Public Companies. New York: COSO.

Beasley, M. S., J. V. Carcello, D. R. Hermanson, and T. L. Neal. 2010. Fraudulent Financial Reporting: 1998-2007, An Analysis of U.S. Public Companies. New York: COSO. 
Becker, C. L., M. DeFond, J. Jiambalvo, and K. Subramanyam. 1998. The effect of audit quality on earnings management. Contemporary Accounting Research 15: 1-22.

Bergstresser, D. and T. Philippon. 2006. CEO incentives and earnings management. Journal of Financial Economics 80: 511-529.

Bhagat, S., N. Moyen, and I. Suh. 2005. Investment and internal funds of distressed firms. Journal of Corporate Finance 11: 449-472.

Biddle, G. C., and G. Hillary. 2006. Accounting quality and firm-level capital investment. The Accounting Review 81 (5): 963-982.

Biddle, G. C., G. Hillary, and R. S. Verdi. 2009. How does financial reporting quality relate to efficiency? Journal of Accounting and Economics 48: 112-131.

Bohn, G. 2010. A new wave in green energy fraud: Fraudsters are learning it pays to be green. Fraud Magazine 24 (5): 36-41.

Boo, E., and D. Sharma. 2008. The association between corporate governance and audit fees of bank holding companies. Corporate Governance 8 (1): 28-45.

Bragdon, J. H., and J. A. T. Marlin. 1972. Is pollution profitable? Risk Management 19 (4): 9-18.

Brazel, J. F., K. L. Jones, and D. F. Prawitt. 2010. Improving fraud detection: Do auditors react to abnormal inconsistencies between financial and nonfinancial measures? Working paper, North Carolina State University.

British PetroleumCorporation. 2006. 10-K Annual Report 2006.

Broussard, J. P. 2004. CEO incentives, cash flow, and investment. Financial Management 33 (2): 51-70.

Burgstahler, D., and I. Dichev. 1997. Earnings management to avoid earnings decreases and losses. Journal of Accounting and Economics 24: 99-126. 
Carcello, J. V., D. R. Hermanson, T. L. Neal, and R. A. Riley Jr. 2002. Board characteristics and audit fees. Contemporary Accounting Research 19 (3): 365384.

Chen, J. C., D. M. Patten, and R. W. Roberts. 2008. Corporate charitable contributions: A corporate social performance or legitimacy strategy. Journal of Business Ethics 82 (1): $131-144$.

ChevronTexaco Corporation. 2004. 10-K Annual Report 2004.

.2005. 10-K Annual Report 2005.

.2006. 10-K Annual Report 2006.

Cho, C. H., D. M. Patten, and R. W. Roberts. 2006. Corporate political strategy: An examination of the relation between political expenditures, environmental performance, and environmental disclosure. Journal of Business Ethics 67 (2): $139-154$.

Cho, C. H., R. W. Roberts, and D. M. Patten. 2009. The language of US corporate environmental disclosure. Accounting, Organizations and Society. Forthcoming.

Choi, J., J. Kim, and Y. Zang. 2010. Do abnormally high audit fees impair audit quality. Auditing: A Journal of Practice \& Theory 29 (2): 115-140.

Clarkson, P. M., Y. Li, G. D. Richardson, F. P. Vasvari. 2008. Revisiting the relation between environmental performance and environmental disclosure: An empirical analysis. Accounting, Organizations and Society 33 (4-5): 303-327.

Cleary, S. 1999. The relationship between firm investment and financial status. The Journal of Finance 54 (2): 673-692.

Cohen, D. A., and P. Zarowin. 2010. Accrual-based and real earnings management activities around seasoned equity offerings. Journal of Accounting and Economics 50: 2-19. 
Cronin, C. 2001. Corporate social responsibility in Australia: A select review of the literature. Background Paper No. 3, Research and Social Policy Team. The Smith Family: 1-28.

Darnall, N., S. Inshik, and J. Sarkis. 2009. Perceived stakeholder influences and organizations' use of environmental audits. Accounting, Organizations and Society 34 (2): 170-187.

Das, S., and H. Zhang. 2003. Rounding up in reported EPS, behavioral thresholds and earnings management. Journal of Accounting and Economics 35: 31-50.

David, P., M. Bloom, and A. Hillman. 2007. Investor activism, managerial responsiveness, and corporate social performance. Strategic Management Journal 28: 91-100.

Davis, L. R., D. N. Ricchiute, and G. Trompeter. 1993. Audit effort, audit fees, and the provision of nonaudit services to audit clients. The Accounting Review 68: 135150.

Dechow, P. M., S. A. Richardson, and A. I. Tuna. 2000. Are benchmark beaters doing anything wrong? Working paper. University of Michigan.

Dechow, P. M., R. Sloan, and A. Sweeney. 1996. Causes and consequences of earnings manipulation: an analysis of firms subject to enforcement actions by the SEC. Contemporary Accounting Research 13 (1): 1-36.

DeFond, M. L., and J. Jiambalvo. 1991. Incidence and circumstances of accounting errors. The Accounting Review 66: 643-655.

DeFond, M., K. Raghunandan, and K. R. Subramanyam. 2002. Do non-audit service fees impair audit independence? Evidence from going concern audit opinions. Journal of Accounting Research 40: 1246-1274. 
Dhaliwal, D., S. Radhakrishnan, A. Tsang and Y. G. Yang. 2010a. Nonfinancial disclosure and analyst forecast accuracy: International evidence on corporate social responsibility (CSR) disclosure. Working Paper, The University of Arizona.

Dhaliwal, D., V. Naiker and F. Navissi. 2010b. The association between accruals quality and the characteristics of accounting experts and mix of expertise on audit committees. Contemporary Accounting Research 27 (3): 787-827.

Dittenhofer, M. 1995. Environmental accounting and auditing. Managerial Auditing Journal 10 (8): 40-51.

Douglas, T. J., and W. Q. J. Judge. 1995. Integrating the natural environment into the strategic planning process: An empirical assessment. Academy of Management Best Papers Proceedings: 475-479.

Ettredge, M., C. Li, S. Scholz. 2007. Audit fees and auditor dismissals in the SarbanesOxley era. Accounting Horizons 21 (4): 371-386.

Etzioni, A. 1988. The Moral Dimension. New York, NY: Free Press.

Fama, E., and K. French. 2010. www.mba.tuck.dartmouth.edu.

FirstEnergy. 2006. 10-K Annual Report 2006.

Fombrun, C. J., N. A. Gardberg, and M. L. Barnett. 2000. Opportunity platforms and safety nets: corporate citizenship and reputational risk. Business and Society Review 105 (1): 85-106.

FPL Group, Inc. 2006. 10-K Annual Report 2006.

Francis, J. D., D. Philbrick, and K. Schipper. 1994. Shareholder litigation and corporate disclosures. Journal of Accounting Research 32: 137-164. 
Frankel, R. M. , M. F. Johnson, and K. K. Nelson. 2002. The relation between auditors' fees for non-audit services and earnings management. The Accounting Review 77: 71-105.

Fry, L. W., G. D. Keim, and R. E. Meiners. 1982. Corporate contributions: altruistic or for-profit? Academy of Management Journal 25 (1): 94-106.

Guenster N., J. Derwall, R. Bauer, and K. Koedijk. 2006. The economic value of corporate eco-efficiency. Paper presented at the conference of the Academy of Management, Honolulu, Hawaii.

Ghosh, A., and R. Pawlewicz. 2009. The impact of regulation on auditor fees: Evidence from the Sarbanes-Oxley act. Auditing: A Journal of Practice \& Theory 28 (2): 171-197.

Han, S., T. Kang, and L. Rees. 2009. The association between institutional ownership and audit properties. Working paper, Singapore Management University.

Hausman, J. A. 1978. Specification tests in econometrics. Econometrica (46): 1252-1271.

Hay, D. C., and W. R. Knechel. 2010. The effects of advertising and solicitation on audit fees. Journal of Accounting and Public Policy 29 (1): 60-81.

Hay, D. C., W. R. Knechel, and H. Ling. 2008. Evidence on the impact of internal control and corporate governance on audit fees. International Journal of Accounting (12): 9-24.

Hay, D. C., W. R. Knechel, and N. Wong. 2006. Audit fees: A meta-analysis of the effect of supply and demand attributes. Contemporary Accounting Research 23 (1): 141191.

Hayashi, F. 1982. Tobin's marginal q and average q: A neoclassical interpretation. Econometrica 50 (1): 213-224. 
Herda, D. N., and M. E. Taylor. 2009. A worldwide comparison of assurance on corporate social responsibility reports: Are audit firms willing to sustain this line of service? Working paper, University of Texas at Arlington.

Hill, R. P., T. Ainscough, T. Shank, and D. Manullang. 2007. Corporate social responsibility and socially responsible investing: A global perspective. Journal of Business Ethics 70 (2): 165-174.

Hillman, A. J., and G. D. Keim. 2001. Shareholder value, stakeholder management, and social issues: What's the bottom line? Strategic Management Journal 22 (2): 125139.

Hirst, D. E. and L. Koonce. 1996. Audit analytical procedures: A field investigation. Contemporary Accounting Research 13 (Fall): 457-486.

Hogan, C. E., and M. S. Wilkins. 2008. Evidence on the audit risk model: Do auditors increase audit fees in the presence of internal control deficiencies? Contemporary Accounting Research 25 (1): 219-242.

Hoitash, R., U. Hoitash, and J. C. Bedard. 2008. Internal control quality and audit pricing under the Sarbanes-Oxley act. Auditing: A Journal of Practice \& Theory 27 (1): 105-126.

Hovakimian, G. 2009. Determinants of investment cash flow sensitivity. Financial Management Spring 2009: 161-183.

Johnson, R. A., and D. W. Greening. 1999. The effects of corporate governance and institutional ownership types on corporate social performance. The Academy of Management Journal 42 (5): 564-574.

Kassinis, G., and N. Vafeas. 2002. Corporate boards and outside stakeholders as determinants of environmental litigation. Strategic Management Journal 23 (5): $399-415$.

Kealey, B. T., H. Y. Lee, M. T. Stein. 2007. The association between audit-firm tenure and audit fees paid to successor auditors: Evidence from Arthur Andersen. Auditing: A Journal of Practice \& Theory 26 (2): 95-116. 
Kennedy, P. 1992. A Guide to Econometrics. Cambridge, MA: MIT Press.

KLD Research \& Analytics, Inc. 2006. Getting Started With KLD Stats and Ratings Definitions. Available at: http://wrds.wharton.upenn.edu/ds/kld/manuals/rating.pdf.

Knyazeva, D. 2007. Corporate governance, analyst following, and firm behaviour. Working paper. New York University.

Kothari, S. P., A. J. Leone, and C. E. Wasley. 2005. Performance matched discretionary accrual measures. Journal of Accounting and Economics 39: 163-197.

KPMG. 2002. KPMG International survey of corporate responsibility reporting 2002. Available at: http://www.kpmg.com.

. 2005. KPMG International survey of corporate responsibility reporting 2005. Available at: http://www.kpmg.com.

Lang, L., E. Ofck, and R. M. Stulz. Leverage, investment, and firm growth. Journal of Financial Economics 40: 3-29.

Leonard, M. 1997. Count on Them in. Corporate America is Eager to Volunteer Help to the Needy. The Reason is the Bottom-Line. The Boston Globe: April 20, 1997.

Lev, B., C. Petrovits, and S. Radhakrishan. 2010. Is doing good good for you? How corporate charitable contributions enhance revenue growth. Strategic Management Journal 31 (2): 182-200.

Lin, S., S. Radhakrishnan, and L. Su. 2008. Earnings management and guidance for meeting or beating analysts' earnings forecasts. Working paper. University of Texas at Dallas.

Lindgreen, A., V. Swaen, and W. J. Johnson. 2009. Corporate social responsibility: an empirical investigation of U.S. organizations. Journal of Business Ethics 855: 303-323. 
Mahoney, L., and R. Roberts. 2007. Corporate social performance, financial performance and institutional ownership. Accounting Forum 31 (3): 233-253.

Maignan, I., and O.C. Ferrell. 2001. Antecedents and benefits of corporate citizenship: an investigation of French Businesses. Journal of Business Research 51 (1): 37-51.

Maignan, I., O. C. Ferrell, and T. Hult. 1999. Corporate citizenship: cultural antecedents and business benefits. Journal of the Academy of Marketing Science 27 (4): 455469.

Maremont, M., and L. Cohen. 2002. How Tyco's CEO Enriched Himself. The Wall Street Journal: August 7, 2002.

Matsumoto, D. A. 2002. Management's incentives to avoid negative earnings surprises. The Accounting Review 77: 485-514.

Melancon, B. 2010. An Interview with AICPA President and CEO Barry Melancon, CPA. New Accountant (736): 5 and 22. Reprinted with permission from the AICPA's 12/15/09 CPA Letter Daily Special Report.

Mitchell, J. 2010. Corporate News: White house backs electric car. The Wall Street Journal: June 23, 2010.

Mitra, S. 2002. The impact of institutional stock ownership on a firm's earnings management practice: an empirical investigation. Working paper. Louisiana State University.

Mitra, S. 2009. Pervasiveness, severity, and remediation of internal control material weaknesses under SOX Section 404 and audit fees. Review of Accounting \& Finance 8 (4): 369-387.

Mitra, S., M. Hossain, and D. R. Deis. 2007. The empirical relationship between ownership characteristics and audit fees. Review of Quantitative Finance and Accounting 28 (3): 241-255. 
Muniandy, B. 2007. CEO duality, audit committee effectiveness and audit risks; A study of the Malaysian market. Managerial Auditing Journal 22 (7): 716-728.

Myers, J. N., L. A. Myers, T. C. Omer. 2003. Exploring the term of the auditor-client relationship and the quality of earnings: a case for mandatory auditor rotation? The Accounting Review 78 (3): 779-799.

Naiker, V., and D. S. Sharma. 2009. Former audit partners on the audit committee and internal control deficiencies. The Accounting Review 84 (2): 559-587.

O'Keefe, T., R. King, and K. Gaver. 1994. Audit fees, industry specialization, and compliance with GAAS reporting standards. Auditing: A Journal of Practice \& Theory (Fall): 41-55.

Payne, J. L., and S. W. G. Robb. 2000. Earnings management: the effect of ex-ante earnings expectations. Journal of Accounting, Auditing, and Finance 15: 371-392.

Pfizer Corporation. 2006. 10-K Annual Report 2006.

Plank, W. 2010. The $40^{\text {th }}$ Anniversary of Earth Day (A Special Report) - Milestones in Green Consuming: From the new-car lot to the recycling bin. The Wall Street Journal: April 17, 2010.

Pulliam, S., and D. Solomon. 2002. Uncooking the Books: How Three Unlikely Sleuths Discovered Fraud at WorldCom. The Wall Street Journal: Oct. 30, 2002.

Raghunandan, K., and D. Rama. 2006. SOX Section 404 material weakness disclosures and audit fees. Auditing: A Journal of Practice \& Theory 25 (1): 99-114.

Rajgopal, S., and M. Venkatachalam. 1997. The role of institutional investors in corporate governance: an empirical investigation. Working paper. Stanford University.

Schelleman, C. and W. R. Knechel. 2010. Short-term accruals and the pricing and production of audit services. Auditing: A Journal of Practice \& Theory 29 (1): 221-250. 
Schwartz, M. S., T. W. Dunfee, and M. J. Kline. 2005. Tone at the top: An ethics code for directors? Journal of Business Ethics 58: 79-100.

Securities and Exchange Commission (SEC). 2010. Commission Guidance Regarding Disclosure Related to Climate Change. Release Nos. 33-9106, 34-61469, FR-82. Washington, D.C.: SEC.

Semenova, N., and L.G. Hassel. 2008. Financial outcomes of environmental risk and opportunity for US companies. Sustainable Development 16 (3): 195-212.

Sharfman, M. P., and C. S. Fernando. 2008. Environmental risk management and the cost of capital. Strategic Management Journal 29 (June): 569-592.

Sharma, V. D. 2004. Board of director characteristics, institutional ownership, and Fraud: Evidence from Australia. Auditing: A Journal of Practice and Theory 23 (2): 105117.

Sherman, S. 1997. Levis: as ye sew, so shall ye reap. Fortune 135 (9): 104.

Simnett, R., A. Vanstraelen, and W.F. Chua. 2009a. Assurance on sustainability reports: An international comparison. The Accounting Review 84 (3): 937-967.

Simnett, R., M. Nugent, and A. L. Huggins. 2009b. Developing an international standard on greenhouse gas statements. Accounting Horizons 23 (4): 347-363.

Social Investment Forum. 2010. Performance and Socially Responsible Investments. Available at: http://www.socialinvest.org/resources/performance.cfm.

Spicer, B. 1978. Investors, Corporate social performance and information disclosure. The Accounting Review 53 (1): 94-111.

The Dow Chemical Company. 2006. 10-K Annual Report 2006. 
Tichy, N. M., A. R. McGill, and L. St. Clair. 1997. Corporate Global Citizenship: Doing Business in the Public Eye. San Francisco, CA: The New Lexington Press.

Tobin, J. 1969. A general equilibrium approach monetary theory. Journal of Money, Credit and Banking 1: 15-29.

Trex Company, Inc. 2006. 10-K Annual Report 2006.

Trompeter, G. and A. Wright. 2010. The world has changed; have analytical procedure practices? Contemporary Accounting Research (forthcoming).

Turban, D. B., and D. W. Greening. 1997. Corporate social performance and organizational attractiveness to prospective employees. Academy of Management Journal 40 (3) 658-672.

Van Dyne, L., J. W. Graham, and R. M. Dienesch. 1994. Organizational citizenship behavior: construct redefinition, measurement and validation. Academy of Management Journal: 765-802.

Venkataraman, R., J. P. Weber, and M. Willenborg. 2008. Litigation risk, audit quality, and audit fees: Evidence from initial public offerings. The Accounting Review 83 (5): 1315-1345.

Vermeer, T. E., D. V. Rama, and K. Raghunandan. 2008. Partner familiarity and audit fees: Evidence from former Andersen clients. Auditing: A Journal of Practice \& Theory 27 (2): 217-229.

Waddock, S. A., and S. B. Graves. 1997. The corporate social performance-financial performance link. Strategic Management Journal 18 (4): 303-319.

Waters Corporation. 2006. 10-K Annual Report 2006.

Watson, M., and J. MacKay. 2003. Auditing for the environment. Managerial Auditing Journal 18 (8): 625-630. 
Webb, E. 2004. An examination of socially responsible firms' board structure. Journal of Management and Governance 8 (3): 255-277.

Wells, J. T. 2008. Principles of Fraud Examination. Wiley: New Jersey.

White, H. 1980. A heteroscedasticity-consistent covariance matrix estimator and a direct test for heteroscedasticity. Econometrica 48: 817-838.

Whited, T. M. 1992. Debt, liquidity constraints, and corporate investment: Evidence from panel data. The Journal of Finance 47 (4): 1425-1460.

Yoshikawa, H. 1980. On the "q" theory of investment. American Economic Review 70 (4): 739-743.

Yu, F. 2008. Analyst coverage and earnings management. Journal of Financial Economics 88: 245-71. 


\begin{tabular}{|c|c|c|}
\hline \multicolumn{3}{|c|}{ APPENDIX: EXAMPLES OF ENVIRONMENTAL INITIATIVES } \\
\hline Initiative Type & Company & Example \\
\hline $\begin{array}{l}\text { Environmental } \\
\text { Products and Services } \\
\text { (PROD_SERV) }\end{array}$ & $\begin{array}{c}\text { Waters } \\
\text { Corporation }\end{array}$ & $\begin{array}{l}\text { The Company's Waters instruments (LC and MS) are utilized in this broad range of industries to detect, } \\
\text { identify, monitor and measure the chemical, physical and biological composition of materials as well as } \\
\text { to purify a full range of compounds. These instruments are used in drug discovery and development, } \\
\text { including clinical trial testing, the analysis of proteins in disease processes (known as "proteomics"), } \\
\text { food safety analysis and environmental testing (Waters Corporation 2006). }\end{array}$ \\
\hline $\begin{array}{l}\text { Pollution Prevention } \\
\text { (POLL_PREV) }\end{array}$ & $\begin{array}{c}\text { 3M } \\
\text { Company }\end{array}$ & $\begin{array}{l}\text { Capital expenditures for environmental purposes have included pollution control devices - such as } \\
\text { wastewater treatment plant improvements, scrubbers, containment structures, solvent recovery units } \\
\text { and thermal oxidizers - at new and existing facilities constructed or upgraded in the normal course of } \\
\text { business. Consistent with the Company's policies stressing environmental responsibility, capital } \\
\text { expenditures... for known projects are presently expected to be about } \$ 20 \text { million over the next two } \\
\text { years for new or expanded programs to build facilities or modify manufacturing processes to minimize } \\
\text { waste and reduce emissions (3M Company 2006). }\end{array}$ \\
\hline $\begin{array}{l}\text { Recycling Initiatives } \\
\text { (RECYCLE) }\end{array}$ & $\begin{array}{l}\text { Trex } \\
\text { Company, } \\
\text { Inc. }\end{array}$ & $\begin{array}{l}\text { Through capital investments and process engineering, I continuously seek to lower the all-in cost to } \\
\text { manufacture Trex products. Investments in plastic recycling capabilities will allow us to expand my } \\
\text { ability to use a wider breadth of waste streams and as a result lower my raw material costs (Trex } \\
\text { Company, Inc. 2006). }\end{array}$ \\
\hline $\begin{array}{l}\text { Climate Protection } \\
\text { (CLIMATE) }\end{array}$ & $\begin{array}{l}\text { FPL Group, } \\
\text { Inc. }\end{array}$ & $\begin{array}{l}\text { As a participant in President Bush's Climate Leader Program to reduce greenhouse gas intensity in the } \\
\text { United States by } 18 \% \text { by } 2012 \text {, FPL Group has inventoried its greenhouse gas emission rates and has } \\
\text { committed to a } 2008 \text { reduction target of } 18 \% \text { below a } 2001 \text { baseline emission rate measured in pounds } \\
\text { per megawatt-hour. FPL Group believes that the planned operation of its generating portfolio, along } \\
\text { with its current efficiency initiatives, greenhouse gas management efforts and increased use of } \\
\text { renewable energy, will allow it to achieve this target. In addition, FPL Group has joined the U.S. } \\
\text { Climate Action Partnership, an alliance made up of a diverse group of U.S.-based businesses and } \\
\text { environmental organizations, which in early } 2007 \text { issued a set of principles and recommendations to } \\
\text { address global climate change and the reduction of greenhouse gas emissions (FPL Group, Inc. 2006). }\end{array}$ \\
\hline $\begin{array}{l}\text { Other } \\
\text { Environmentally } \\
\text { Proactive Initiatives } \\
\text { (OTHER) }\end{array}$ & $\begin{array}{l}\text { The Dow } \\
\text { Chemical } \\
\text { Company }\end{array}$ & $\begin{array}{l}\text { Dow is committed to world-class environmental, health and safety ("EH\&S") performance, as } \\
\text { demonstrated by a long-standing commitment to Responsible Care }{ }^{\circledR} \text {, the significant progress made by } \\
\text { the Company over a } 10 \text {-year period toward Dow's EH\&S Goals for } 2005 \text {, and the development of } \\
\text { Dow's new } 2015 \text { Sustainability Goals. In } 2005 \text {, Dow developed its next generation of } 10 \text {-year goals that } \\
\text { will provide continuity to the first set of goals, while also addressing a broader set of challenges. The } \\
2015 \text { Sustainability Goals will set the standard for sustainability in the chemical industry by focusing } \\
\text { on improvements in Dow's local corporate citizenship and product stewardship, and by actively } \\
\text { pursuing methods to reduce the Company's environmental impact (The Dow Chemical Company 2006). }\end{array}$ \\
\hline
\end{tabular}


VITA

BARRI ALEXANDRA LITT

$\begin{array}{ll}\text { 2003-2006 } & \begin{array}{l}\text { B.S., Accounting } \\ \text { University of Florida } \\ \text { Gainesville, Florida } \\ \text { Perfect 4.0 GPA }\end{array} \\ \text { M.S., Accounting } \\ \text { University of Florida } \\ \text { Gainesville, Florida } \\ \text { Thesis in Corporate Social Responsibility } \\ \text { Certification of Public Accountancy } \\ \text { AICPA } \\ \text { PhD. Candidate, Business Administration } \\ \text { Florida International University } \\ \text { Miami, Florida } \\ \text { Graduate Research and Teaching Assistant } \\ \text { Florida International University } \\ \text { Miami, Florida } \\ \text { Assistant Professor of Accounting } \\ \text { Nova Southeastern University } \\ \text { Davie, Florida }\end{array}$

\section{SPECIAL DISTINCTIONS}

2007 Elijah Watt Sells Award Recipient for achieving a Top 10 score on the Certified Public Accountancy (CPA) Exam of over 50,000 candidates

2007-2008: Ernst \& Young, LLP Top Staff Accountant reviews for work in Assurance and Auditing Services 